\title{
Verplegen in het psychiatrisch centrum : een onderzoek naar taken van psychiatrisch verpleegkundigen
}

\author{
Citation for published version (APA): \\ Dassen, T. W. N. (1989). Verplegen in het psychiatrisch centrum : een onderzoek naar taken van \\ psychiatrisch verpleegkundigen. [Doctoral Thesis, Maastricht University]. Rijksuniversiteit Limburg. \\ https://doi.org/10.26481/dis.19890921td
}

Document status and date:

Published: 01/01/1989

DOI:

10.26481/dis.19890921td

Document Version:

Publisher's PDF, also known as Version of record

\section{Please check the document version of this publication:}

- A submitted manuscript is the version of the article upon submission and before peer-review. There can be important differences between the submitted version and the official published version of record. People interested in the research are advised to contact the author for the final version of the publication, or visit the DOI to the publisher's website.

- The final author version and the galley proof are versions of the publication after peer review.

- The final published version features the final layout of the paper including the volume, issue and page numbers.

Link to publication

\footnotetext{
General rights rights.

- You may freely distribute the URL identifying the publication in the public portal. please follow below link for the End User Agreement:

www.umlib.nl/taverne-license

Take down policy

If you believe that this document breaches copyright please contact us at:

repository@maastrichtuniversity.nl

providing details and we will investigate your claim.
}

Copyright and moral rights for the publications made accessible in the public portal are retained by the authors and/or other copyright owners and it is a condition of accessing publications that users recognise and abide by the legal requirements associated with these

- Users may download and print one copy of any publication from the public portal for the purpose of private study or research.

- You may not further distribute the material or use it for any profit-making activity or commercial gain

If the publication is distributed under the terms of Article $25 \mathrm{fa}$ of the Dutch Copyright Act, indicated by the "Taverne" license above, 
. 
VERPLEGEN IN HET PSYCHIATRISCH CENTRUM 



\title{
VERPLEGEN IN HET PSYCHIATRISCH CENTRUM
}

\author{
een onderzoek naar taken van psychiatrisch \\ verpleegkundigen
}

\author{
Proefschrift \\ ter verkrijging van de graad van doctor \\ aan de Rijksuniversiteit Limburg te Maastricht, \\ op gezag van de Rector Magnificus, Prof. Dr. F.I.M. Bonke, \\ volgens het besluit van het College van Dekanen, \\ in het openbaar te verdedigen \\ op donderdag, 21 september 1989 om 14.00 uur
}

door

Theodoor Wilhelm Nicolaas Dassen

geboren te Kerkrade in 1953 
Promotor:

Beoordelingskommissie: Prof. Dr. F.C.B. van Wijmen (voorzitter) Prof. Dr. A.HM. van den Bergh-Braam Prof. Dr. J.J.C.B Bremer

Prof. Dr. A. Hazewinkel

Prof. Dr. M.M.W. Richantz

Dr. A. Visser

T.W.N. Dassen

produktie: Datawyse Maastricht

druk: Krips Repro Meppel 


\section{WOORD VOORAF}

Aan het onderzoek dat hier gepresenteerd wordt is door meer dan duizend psychiatrisch verpleegkundigen meegewerkt. Hun bijdrage bestond uit deelname aan interviews, het invullen van een enquête of het, uit hoofde van hun funktie, verlenen van toestemming voor de uitvoering van het onderzoek in de betreffende psychiatrische centra. Zonder hun medewerking zou dit verslag nooit geschreven zijn.

Meer 'achter de schermen' is medewerking verleend door vele anderen die behulpzaam waren bij de verwerking van de gegevens en de interpretatie van de resultaten. Ook hun medewerking is van groot belang geweest voor de afronding van dit onderzoek.

Het is onmogelijk on iedereen hier met name te noemen. Ik beperk mij daarom tot de leden van de begeleidingskommissie: Prof.Dr.H.Philipsen, die gewaakt heeft over het verantwoord omgaan met de gegevens; Dr.R.Halfens die vooral de technische kant van het onderzoek in de gaten hield; dhr.G.Brouns en Dr.R.Bambang Oetomo, die door hun bekendheid met het terrein van onderzoek behulpzaam waren bij de soms moeilijk keuzes die nodig waren woor het afbakenen van thet onderzoeksdomein. Eveneens is dank verschuldigd aan de leden van de beoordelingskommissie, die met hun adviezen ertoe bijgedragen hebben dat het geheel een konsistent en leesbaar proefschrift werd.

Tot slot wil ik hier de wens uitspreken dat dit onderzoek een zinvolle bijdrage levert aan de diskussies rond het beroep van psychiatrisch verpleegkundige en indirekt bijdraagt aan de kwaliteit van de zorgverlening voor de psychiatrische patiënt. 



\section{INHOUDSOPGAVE}

INLEIDING

1. ONTWIKKELINGEN IN DE PSYCHIATRISCHE VERPLEGING

1.1. De opleiding tot psychiatrisch verpleegkundige 14

1.2. Taken van psychiatrisch verpleegkundigen 19

1.3. Beroepsidentiteit van de psychiatrisch verpleegkundige 24

1.4. Algemene ontwikkelingen in de verpleegkunde die van invloed zijn op de psychiatrische verpleging

1.5. De zorg voor de chronische psychiatrische patiënt 29

1.6. De verpleegkundige als begeleider van de chronische patiënt 31

1.7. Vraagstellingen 34

2. INTERVIEWS MET PSYCHIATRISCH VERPLEEGKUNDIGEN 35

2.1. Werkwijze 35

2.2. Onderzoekspopulatie 36

2.3. Taken van psychiatrisch verpleegkundigen 37

2.4. Positie van de psychiatrisch verpleegkundige binnen de
organisatie van de psychiatrische centra

2.5. Positie van de psychiatrisch verpleegkundige binnen de $\begin{array}{ll}\text { verpleegkundige beroepsgroep } & 44\end{array}$

2.6. Chroniciteit 45

2.7. Algemene bevindingen 45

3. HET ONDERZOEKSMODEL 49

3.1. Het algemene onderzoeksmodel 49

3.2. Taakopvattingen 51

3.3. Opvattingen over chroniciteit en beroepsidentifikatie 53

3.4. Burnout 54

3.5. Aard van de zorgverlening $\quad 56$

3.6. Persoonskenmerken 56

3.7. Psychiatrische centra 57

4. HET HOOFDONDERZOEK

4.1. 'Onderzoekspopulatie 59

4.2. De steekproef 60

4.3. Werkwijze 60

4.4. Instrumentontwikkeling 61

4.5. Deelnemende instellingen 61

4.6. Respons 62

4.7. Achtergrondkenmerken wan de respondenten 64

4.8. Selektie van variabelen voor het onderzoek 68 
5.1. Tijdsbesteding 69

5.2. Het meten van de takopvattingen $\quad 70$

5.3. Taakopvattingen naar persoonskenmerken $\quad 82$

5.4. Taakopvattingen naar sektor en instelling 84

6. CHRONICITEIT, IDENTIFIKATIE EN BURNOUT 87

$\begin{array}{ll}\text { 6.1. Visie op chronicitieit } & 87\end{array}$

6.2. Beroepsidentifikatie 91

6.3. Burnout 96

6.4. Samenhang chroniciteit, identifikatie en burnout

7. VERKLARING VAN VERSCHILLEN IN TAAKOPVATTINGEN 103

7.1. Samenhang taakopvattingen met visies op chroniciteit, identifikatie en burnout

7.2. Multivariate samenhangen tussen de taakopvattingen en de verklarende variabelen

7.3. Bespreking van de belangrijkste verklarende variabelen 106

8. SLOTBESCHOUWING

8.1. Konklusies 113

8.2. Diskussie 116

8.3. Beperkingen en aanbevelingen 120

SAMENVATTING 123

LIJST MET GEBRUIKTE AFKORTINGEN 126

$\begin{array}{ll}\text { LITERATUUR } & 127\end{array}$

$\begin{array}{ll}\text { BIJLAGE } & 133\end{array}$

A. Interviews 134

B. Schalen 136

C. Faktortabel aktiviteiten 139

$\begin{array}{ll}\text { SUMMARY } & 141\end{array}$

CURRICULUM VITAE 144 


\section{INLEIDING}

De ontwikkeling in de intramurale zorg voor de psychiatrische patiënt gedurende de afgelopen vijftig jaar kan gekenmerkt worden als: van verzorgingsgericht naar begeleidingsgericht. Binnen de verzorgingsgerichtheid werd met name aandacht besteed aan lichamelijke hygiëne, orde en netheid. Daarnaast werd getracht om via medische behandelingen de patiënten te genezen van hun kwalen. Geleidelijk aan ontstond, vooral door de invloed van de sociale wetenschappen, het inzicht dat de wijze waarop de zorg voor de psychiatrische patiënt georganiseerd was juist de afhankelijkheid van deze patiënten bevorderde. Psychiatrische patiënten waren in hun doen en laten namelijk onderworpen aan het inrichtingsregiem. De vooruitzichten op een terugkeer in de maatschappij buiten de instellingen werden daardoor alleen maar bemoeilijkt. Patiënten dienden daarom een zo gericht mogelijke behandeling te krijgen en zo kort mogelijk opgenomen te worden in de psychiatrische centra. Dit gold uiteraard niet voor de patiënten die al lang, soms wel veertig jaar, in de psychiatrische instellingen woonden. Deze chronische patiënten dienden meer zelfstandigheid te krijgen en zoveel mogelijk in kleinschalige woonvormen buiten de inrichtingen gehuisvest te worden. Het aksent van de hulpverlening kwam daarmee te liggen op begeleiding van, in plaats van, zorgen vóór de patiënten.

De veranderde opvattingen over de hulpverlening aan chronische patiënten leidde tot veranderingen in de taken van de psychiatrische verpleegkundigen. In die taken was sprake van een aksentverschuiving naar begeleiding. De psychiatrisch verpleegkundige ging zich daardoor onderscheiden van de ziekenhuisverpleegkundige.

Op de afdelingen voor kortdurende behandeling van psychiatrische patiënten, de zogenaamde shortstay-afdelingen, raakte de psychiatrisch verpleegkundige meer betrokken bij de behandeling. De rol van deze verpleegkundigen werd daarmee een van mede-behandelaar van de patiënt.

Deze ontwikkelingen hebben geleid tot de 'identiteitskrisis' van de psychiatrische verpleegkunde. Enerzijds is er onduidelijkheid omtrent de taken van psychiatrisch verpleegkundigen; anderzijds is er diskussie omtrent de beroepsidentiteit: is psychiatrische verpleging nog well een verpleegkundig beroep? De diskussie omtrent de beroepsrol hangt samen met de veranderde taken van de psychiatrisch verpleegkundigen.

Zoals reeds vermeld werd was het de invloed van de sociale wetenschappen die mede leidde tot de gewijzigde opvattingen omtrent de behandeling van psychiatrische patiënten. Met name in de sociale wetenschappen ging men er van uit dat de oorzaken van chroniciteit niet verklaard dienden te worden vanuit de patiënt zelf (als ziekte), doch vanuit omgevingsfaktoren, namelijk het inrichtingsmilieu. De psychia- 
trisch verpleegkundige werd daarbij beschouwd als eén van de faktoren van dat milieu, die de afhankelijkheid van de patiënten bevorderde. Verpleegkundigen waren namelijk opgeleid om de regels van het huis te bewaken en vormden een representant van de medische benadering. Een verandering in deze benadering van de psychiatrische patient diende dus ook uit te gaan van het aanleren van een andere attitude aan de verpleegkundigen. In de opleiding tot psychiatrisch verpleegkundige, die door de psychiatrische instellingen zelf als in-service opleiding gegeven werd, werden daarom ooksocialal-agogische vakken en vaardigheden onderwezen. Leerling-verpleegkundigen werden bewust gemaakt van hun taken bij het tegengaan van het afhankelijk maken van patiënten van het instituut. Hun visie op het ontstaan van chronische patiënten diende een sociaal-wetenschappelijk en niet een medische te zijn.

De taken van psychiatrisch verpleegkundigen staan onder ïnloed van veranderingen, c.q. invloeden vanuit de sociale wetenschappen. Dit kreeg onder andere vorm doordat sociale wetenschappers in de psychiatrische instellingen gingen werken en betrokken raakten bij de behandeling van de patiënten.

In de literatuur wordt over de taken van psychiatrisch verpleegkundigen hoofdzakelijk in ideologische zin geschréven. Hoe die taken er in de dagelijkse praktijk uitzien is nauwelijks onderzocht. Vandaar dat in dit onderzoek de volgende probleemstelling centraal staat:

A. Welke opvattingen hebben psychiatrisch verpleegkundigen omtrent hun taken ten behoeve van psychiatrische patiënten?

Aangezien het onderzoek niet alleen bedoeld is om een inventarisatie van de taken te maken, doch ook enige verklaring van mogelijke verschillen in taakopvattingen wil leveren, is de volgende probleemstelling toegevoegd:

B. Hoe zijn eventuele verschillen in taakopvattingen van psychiatrisch verpleegkundigen te verklaren?

Bij het onderzoek wordt gebruik gemaakt van zowel interviews als schriftelijke enquêtes. De informatie die verkregen wordt via de interviews dient ter nadere oriëntatie op het onderzoeksdomein. De gegevensverzameling voor het hoofdonderzoek heeft plaats gevonden met behulp van een schriftelijke enquête onder psychiatrisch verpleegkundigen in zes psychiatrische centra. Bij dit deel van het onderzoek zijn ook verpleegkundigen die niet bij chronische patiënten werken betrokken. Dit geeft namelijk de mogelijkheid om de bevindingen die betrekking hebben op diegenen die werkzaam zijn bij chronische patiënten te vergelijken met de bevindingen van verpleegkundigen die juist niet belast zijn met de zorg voor chronische patiënten. 
De opbouw van het onderzoeksverslag is als volgt: In het eerste hoofdstuk wordt aandacht besteed aan de ontwikkeling van de taken van psychiatrisch verpleegkundigen. Daarbij wordt eveneens ingegaan op de ontwikkeling van het beroep in het algemeen vanaf het ontstaan van de opleidingen. Ook komt de positie van de psychiatrisch verpleegkundige binnen het verpleegkundig beroep als zodanig aan bod. Daar dit onderzoek met name gericht is op de zorg voor de chronische patiënt, zal ook aandacht besteed worden aan het verschijnsel chroniciteit met betrekking tot psychiatrische patiënten.

In hoofdstuk 2 wordt verslag gedaan van een vooronderzoek dat gehouden werd ter nadere verkenning van het onderzoeksdomein. Daarbij is gebruik gemaakt van semigestruktureerde interviews die gehouden zijn met 52 verpleegkundigen uit vijf psychiatrisch instellingen. Op basis van de informatie uit de literatuur en uit de interviews is uiteindelijk een keuze bepaald voor de in het hoofdonderzoek op te nemen onderzoeksbegrippen die een mogelijk verklaring van de taakopvattingen geven. Het betreft naast enkele relevant geachte persoonskenmerken en het al dan niet door psychiatrisch verpleegkundigen bezitten van een diploma 'inrichtingswerk', de visie op de problematiek van de chronische patiënt, de beroepsidentifikatie en burnout. In hoofdstuk 3 wordt de mogelijke samenhang van die begrippen met de taakopvattingen toegelicht en zal een onderzoeksmodel gepresenteerd worden dat als leidraad voor de analyses zal dienen.

In hoofdstuk 4 worden de opzet en de gekozen werkwijze voor de gegevensverzameling van het hoofdonderzoek besproken. Tevens wordt aandacht besteed aan de bepaling van de steekproef en aan de respons op de enquête. Daarbij worden de relevant geachte persoonskenmerken, zoals leeftijd, geslacht ervaring en funktie van de respondenten aan het onderzoek weergegeven.

De volgende hoofdstukken bevatten de eigenlijke analyses. In hoofdstuk 5 ligt de nadruk op de bespreking van de taakopvattingen. De verklarende variabelen worden besproken in hoofdstuk 6. De samenhang tussen de persoonskenmerken en de overige werklarende variabelen met de taakopvattingen wordt in hoofdstuk 7 met behulp van multivariate analyses nagegaan.

In de slotbeschouwing wordt de konklusie van het onderzoek alsmede enige diskussie omtrent de bevindingen weergegeven. Tot slot worden enkele beperkingen van het onderzoek besproken en zullen enkele aanbevelingen voor verder onderzoek gedaan worden.

Om praktische redenen is soms gebruik gemaakt van afkortingen. Het betreft uitsluitend afkortingen die bij ingewijden in het domein van onderzoek bekend verondersteld worden. Volledigheidshalve is aan het einde van het verslag een verklarende lijst van deze afkortingen opgenomen. 
Van de in de literatuur gebruikelijke afkorting $\mathrm{APZ}$, die staat voor algemeen psychiatrisch ziekenhuis, is geen gebruik gemaakt. De voorkeur werd gegeven aan een afwisselend gebruik van de meer neutrale benamingen psychiatrische instelling en psychiatrisch centrum. 


\section{ONTWIKKELINGEN IN DE PSYCHIATRISCHE VERPLEGING}

\section{Inleiding}

In de geestelijke gezondheidszorg zijn psychiatrisch verpleegkundigen, voor het direkte kontakt met de patiënt, een belangrijke discipline. Ongeveer 12.000 verpleegkundigen en leerling-verpleegkundigen zijn betrokken bij de zorg voor ruim 23,000 psychiatrische patiënten (resp. N.Z.I, 1988 en N.c.G.v., 1987). Voor een groot deel $( \pm 70 \%)$ betreft dit de zorg voor chronische patiënten.

Met name als gevolg van veranderde opvattingen in de geestelijke gezondheidszorg wordt veelvuldig over de zorgverlening aan chronische psychiatrische patiënten gepubliceerd. Over de taken van de psychiatrisch verpleegkundigen daarbij wordt slechts met mondjesmaat geschreven, en dan veelal in ideologische zin.

De veranderingen in de zorgverlening aan chronische patiënten zijn van invloed op de taken van de verpleegkundigen. Behalve ontwikkelingen in de geestelijke gezondheidszorg zijn ook andere faktoren van invloed op het beroep van psychiatrisch verpleegkundige. Dit betreft met name veranderingen in de funktie van verpleegkundigen als beroepsgroep, welke gericht zijn op het verzelfstandigen van de discipline. Een belangrijke gebeurtenis in die ontwikkeling van het verpleegkundig beroep is de oprichting van één algemene basisopleiding voor alle verpleegkundigen. Deze opleiding begint meer en meer de plaats in te nemen van de huidige in-service opleidingen, die gericht zijn op de zorgverlening in éen bepaalde sektor van de gezondheidszorg.

In dit hoofdstuk zal de nadruk liggen op het bespreken van veranderingen in de psychiatrische verpleging. Het ontstaan van de opleiding tot psychiatrisch verpleegkundige wordt als begin van deze ontwikkeling gekozen. Ook ontwikkelingen in die opleiding worden behandeld. Vervolgens wordt aandacht besteed aan de taken van psychiatrisch verpleegkundigen. De diskussie over de beroepsidentiteit van de psychiatrisch verpleegkundige wordt eveneens belicht. Ook worden enkele algemene ontwikkelingen in de verpleging, voor zover van invloed op de verpleging in psychiatrische centra, besproken. Tot slot komen de taken van psychiatrisch verpleegkundigen, met name met betrekking tot de zorgverlening voor de chronische patiënt, aan bod.

Voor alle duidelijkheid wordt erop gewezen dat dit hoofdstuk bedoeld is als een algemene inleiding op de ontwikkelingen van de psychiatrische zorg. Het aksent ligt daarom op de beschrijving van veranderingen in het beroep van psychiatrisch verpleegkundige. Allleen in zoverre dat voor een goed begrip van zaken nodig is, zal aandacht besteed worden aan ontwikkelingen in de psychiatrie. 


\title{
1.1. De opleiding tot psychiatrisch verpleegkundige
}

Aan het einde van de vorige euw ontstonden de eerste opleidingen tot psychiatrisch verpleegkundige. In die tijd was er nog geen sprake van psychiatrisch verplegen, zoals wij dat nu kennen, maar veel meer van oppassen.

De overgang van oppassen naar verplegen, welke de verandering van de omgang met psychatrisch patienten in de $19^{e}$ eeuw en het begin wan de $20^{\circ}$ eeuw markeert wordt treffend getypeerd door Van der Scheer:

\begin{abstract}
De legenstelling tusschen de door ruwe oppassers bewaakte onrustige gekken (razenden genaamd), die in donkere ongezellige zalen bijeengebracht of in duistere, lichtlooze, wochtige cellen, dikwijls aan kettingen vastgelegd of in boeien geklonken, in het leven werden gehouden, en de door geschoold personeel verzorgde geestelijk zieken, die in van lucht en licht voorziene frissche zalen der moderne gestichten, in als ziekenkamertje ingericht eenpersoonskamertie, in bed en in permanentbad, worden verpleegd, is dan ook buitengewoon scherp en contrastrijk
\end{abstract}

(Van der Scheer, 1928; blz. 188)

In die tijd was sprake van behandeling in bed en bad. Ook spreekt de auteur over 'verpleegd worden' "). Deze benadering hangt samen met het feit dat de toenmalige gestichten meer en meer, volgens het Utrechtse model van Schroeder van de Kolk, als ziekenhuis gezien werden. Dit vloeide voort uit een veranderde benadering in de psychiatrie. Deze komt erop neer dat men maatschappelijke ellende en sociale improduktiviteit beschouwde als uitdrukkingen van geestesziekte. Degenen die zich onaangepast gedroegen werden beschouwd als zieken (Fox, e.a 1983). Een gevolg daarvan was onder meer de invoering van de bedverpleging in de psychiatrische inrichtingen. Psychiatrische stoornis werd behandeld als een lichamelijke ziekte. Dit had in ieder geval het voordeel dat men patiënten beter kon observeren (Dane, 1968). Aan de verpleging van krankzinnigen moesten daardoor wel steeds hogere eisen gesteld worden. Een opleiding voor het personeel werd noodzakelijk (Schut, 1970). Immers toewijding, kristelijke liefde en roeping, hoe verdienstelijk ook, bleken niet voldoende (Kramer, 1969). Bovendien zou een opleiding kunnen bijdragen aan een vaster personeelsbestand. Onder het personeel was namelijk sprake van een groot werloop. Deels was dat een gevolg van de afkomst van het personeel, doch ook de lage lonen, de gebrekkige kost en inwoning en het ontbreken van vrije tijd vormden redenen voor het verloop (Vijselaar, 1982). Als oppassers nam men daarom wat er aan personeel te krijgen was, wan landlopers en bedelaars tot ontslagen gevangenen

1) Verplegen werd indertijd gebruikt in de betekenis van verzorgen. Zie Van Dale, Groot Woordenboek der Nederlandsche Taal, (zesde geheel opnieuw bewerkte uitgave, 1924): verplegen, werzorgen: een zieke verplegen; de armen verplegen. verzongen, een zieke verzorgen. 
en uit dienst ontslagen militairen. Het personeel stond bekend als een samentapsel van dronkaards en vagebonden (Van der Laarse-De Bruin, 1981). Van het personed in de krankzinnigengestichten had men dan ook, aan het einde van de vorige eeuw, bepaald geen hoge dunk. Een van de leden van de 'Vereeniging voor Psychiatrie' stelde dit in 1874 als volgt:

Een faisoenlijke verpleegster waagt zich niet in een gezelschap als dat, zoals het tegenwoordig verplegend personeel in de meeste gestichten wordt afgeschilderd.

(Van der Esch, 1975; blz. 75).

In Nederland ontstonden initiatieven tot het oprichten van een opleiding voor de oppassers en oppasseressen. De eerste diploma"s werden in 1893 in het gesticht Meerenberg te Santpoort uitgereikt. De eksamens werden afgenomen door leden van de Nederlandse Vereniging voor Psychiatrie en Neurologie. In andere gestichten gebeurde dit door leden van organisaties die op basis van de overeenkomstige levensbeschouwing de krankzinnigenzorg behartigden (N.R.V., 1983).

Het ging bij de opleidingen aanvankelijk om het aanleren van op de dagelijkse praktijk gerichte gedragskodes. Dus orde, netheid en discipline. Het zwaartepunt van de opleiding lag op de voorschriften inzake orde, netheid, veiligheid en rust. Veiligheid slaat dan op de eigen veiligheid van de verplegende, bijvoorbeeld" altijd achter de patiënt lopen (Peeters en De Vos, 1982).

Met de totstandkoming van de opleiding werden de oppassers en oppasseressen meer als persoon benaderd. Vanaf 1890 werden zij verpleger of verpleegster, dan wel broeder of zuster genoemd (Vijselaar, 1982). Ook het dragen van een uniform werd met de oprichting van de opleidingen verplicht gesteld (Kramer, 1969). Voor broeders betekende dit het dragen van een zwart of grijs pak met een hoog, wit boordje. Verpleegsters en leerling-verpleegsters waren herkenbar aan hun lichtblauwe japon. Eerste verpleegsters droegen een donkerblauwe japon. De hoofdverpleegsters waren gekleed in een stemmig zwarte jurk (Vijselaar 1982).

Op verscheidene plaatsen in het land werden initiatieven tot verbetering van de krankzinnigenzorg genomen. Dit leidde op den duur tot zes verschillende wijzen om het diploma krankzinnigenverpleging te verwerven. In de rijksgestichten was dit mogelijk in twee jaar en twee maanden. In de gestichten van de Vereniging tot Kristelijke Verzorging van Krankzinnigen duurde de opleiding ongeveer drie jaar. In een aantal gestichten kon men voor het diploma van de Nederlandse Vereniging voor Psychiatrie en Neurologie worden opgeleid. De Bond voor Ziekenverpleging. 
werzorgde eveneens een opleiding. Het Witte Kruis en Nosokomos ${ }^{2}$ ) gaven een diploma krankzinnigenverpleging, nadat de kandidaten enige tijd, na het behalen van de door de instelling verstrekte diploma's voor algemene ziekenwerpleging, werkzaam waren geweest in een krankzinnigengesticht (Van der Esch, 1975).

Ondanks de grote verscheidenheid aan opleidingen was men toch tevreden met de resultaten wan de eksamens. Met name de eksamens in de vakken die direkt met verpleging te maken hadden werden door de kandidaten met goed gevolg afgelegd. Meer problemen hadden zij echter met lezen, schrijven, rekenen en Nederlandse taal. Om hier iets aan te doen werden vooropleidingen georganiseerd voor toelating tot de opleiding krankzinnigenverpleging. Door de bij de opleiding betrokken stichtingen en verenigingen werden initiatieven genomen om zowel de toelating tot als de inhoud van de opleiding te verbeteren. In verband met de wensen tot meer eenheid en een centrale regeling ontstond er behoefte aan een landelijk gekoördineerde opleiding (Weisglas, 1981). Men wilde éen opleiding waarin de verpleging in het algemene ziekenhuis, in de gestichten, de kinderen de kraamverpleging geleerd zou worden (Hopman, 1980). De Nederlandse Bond voor Ziekenverpleging erkende de gestichten echter niet als ziekenhuis. Dit had tot gevolg dat er een aparte opleiding voor krankzinnigenverpleging kwam. In de Wet Ziekenverpleging van 1921, waarin de opleidingseisen vastgelegd werden, werden het Witte en het Zwarte Kruis apart geregeld ${ }^{3}$ ). Het onderscheid tussen deze twee opleidingen ging verder dan alleen de inhoud van de opleiding. In de genoemde Wet op de Ziekenverpleging stond de Bverpleging in die zin lager aangeschreven dan de A-verpleging dat met een lagere vooropleiding volstaan kon worden voor toelating tot de B-opleiding ${ }^{4}$ ). Dit had tevens tot gevolg dat de B-opleiding ging fungeren als een soort vooropleiding voor diegenen die liever de hoger aangeschreven A-opleiding wilden volgen, doch niet over de daartoe vereiste vooropleiding beschikten (Bierenbroodspot, 1976).

Belangrijk is in dit verband ook het verschil in afkornst van de verplegers en verpleegsters. Voor de A-opleiding werd geworven onder de dames uit de betere standen. Bij

2) Het Witte Kruis was een in 1875 opgerichte vereniging die tot doel had de overheid te helpen bij] de bestrijding van besmettelijke ziekten.Nosokomos was de in 1900 door inzet van Aletta Jacobs en Aletrino opgerichte beroepswereniging woor verplecgkundigen (Van der Meij - De Leur, 1974).

3) Hoewel de opleidingen officieel Ziekenverpleging A en B heten, is de benaming resp. Witte en Zwarte Kruis voor ingewijden een begrip. Het Witte Kruis stond voor de opleiding A, de algemene ziekenwerpleging. Het Zwarte Kruis stond woor de opleiding $B$, te weten de psychiatrische verpleging. Opmerkelijk daarbij is de kleur van de insignes, waarnaar de benamingen witte en zwarte kruis verwijzen. Het insigne van de B-verpleegkundige heeft wel de vorm van een kruis, doch is blauw, en niet zwart wan kleur. Owerigens wordem dlie insignes niet (meer) gedragen door psychiatrisch verpleegkundigen.

4) In sommige publikaties wordt vermeld dat de B-opleiding in 1929 wettelijk geregeld werd (zie o.a. Binnenkade 1973 en Verwey 1981). De Staatscourant vermeldt de B-opleiding echter al in 1923 bij het uitvoeringsbesluit van de Wet van 1921 (Staatscourant; 1923). 
de B-opleiding werd geen onderscheid gemaakt naar maatschappelijke afkomst en werden ook van meet af aan mannen toegelaten (Hopman, 1980). Wellicht heeft dit te maken met het gegeven dat verpleegkundigen binnen de psychiatrie een bewakersfunktie vervulden, men had hier 'sterke mannen' nodig (Spijker, 1979). Overigens werden verpleegsters alleen toegelaten op vrouwenafdelingen. Mannelijke en vrouwelijke patiënten werden niet alleen strikt gescheiden door de afdelingen; er bestonden zelfs aparte inrichtingen voor mannen en vrouwen. In de inrichtingen voor mannen heeft het zelfs tot ruim na de tweede wereldoorlog geduurd voordat men het aandurfde vrouwelijke verpleegkundigen aan te stellen (Bremer, 1972) ${ }^{5}$ ). Tegenwoordig zijn niet alleen de psychiatrische centra gemengd, doch worden veelal mannen en vrouwen ook op dezelfde afdelingen verpleegd.

De aparte opleiding tot psychiatrisch verpleegkundige bestaat nog steeds. De aard van de opleiding is niet wezenlijk veranderd. Dat wil zeggen dat de psychiatrische centra nog steeds zelf deze in-service opleiding verzorgen. Het afzonderlijke theoretische deel wordt veelal ondergebracht in regionale scholen die dan de opleiding voor enkele instellingen verzorgen. De inhoud van de opleiding is regelmatig aangepast aan de vernieuwde taken van de verpleegkundigen. Ook is de toelatingseis gelijk gesteld aan die van de A-opleiding. Bij de laatste wijziging van de opleiding in 1986 is die vastgesteld op minimaal mavo (of vergelijkbaar niveau, danwel het diploma ziekenverzorgende) en een minimumleeftijd van 17 jaar (dit was voorheen 17 jaar en 7 maanden). Degenen die bij aanvang van de opleiding de leeftijd van 25 jaar hebben bereikt hoeven niet (meer) aan de vooropleidingseis te voldoen.

De duur van de opleiding werd in verband met het invoeren van een werkweek van 36 uren, van 3 jaar op 3 jaar en 4 maanden gebracht. Dit was ook nodig vanwege de uitbreiding van het aantal lesuren van 960 tot 1320 Een belangrijk element van genoemde wijziging is ook dat over de zogenaamde pré-klinische periode (nu 30 weken) geen salaris uitbetaald wordt aan de leerlingen.

De praktijk van de opleiding bestaat uit leerwerkperioden op de verpleegafdelingen. Daarbij moet ervaring opgedaan worden op de afdelingen voor acute, chronische en gerontopsychiatrie.

De leerling-verpleegkundige sluit voor het volgen van de opleiding een leerwerkovereenkomst af met de psychiatrisch instelling waar de praktijkervaring opgedaan wordt. De leerling is dus in dienst van een psychiatrisch centrum.

In 1980 behaalden 1140 leerlingen hun B-diploma, in 1985 waren dat er 868 (Van

5) Dit wil niet zeggen dat vrouwen nooit eerder op mannenafdelingen werkzaam geweest waren. In het gesticht Meerenberg te Santpoort had men al rond de eeuwwisseling ervaring opgedaan met verpleegsters op mannenafdelingen. Door Van Deventer werden verpleegsters, juist vanwege hun vrouwelijke eigenschappen waardoor zij zeer geschikt zouden zijn voor de verpleging, op mannenafdelingen aangesteld. In 1892 werkten er in Meerenberg. 62 wrouwelijke en 71 mannelijke oppassers; in 1903 waren dat er respektievelijk 47 en 87 (Van der Scheer, 1928). 
der Windt, 1988). Deze afname heeft op zijn minst drie redenen. Op de eerste plaats heeft ar een wijziging in de verhouding leerlingen gediplomeerden plaatsgevonden (zie Figuur 1.1.). Op de tweede plaats bestaat tegenwoordig de mogelijkheid om een schoolopleiding op middelbaar of hoger beroepsopleidingsniveau te volgen. Tenslotte is sprake van een afnemende belangstelling voor de opleiding onder het op zich al verminderd aantal schoolverlaters.

a. percentage

(gediplomeerde) verpleegkundigen b. aantal leerling \& gediplomeerd verpleegkundigen

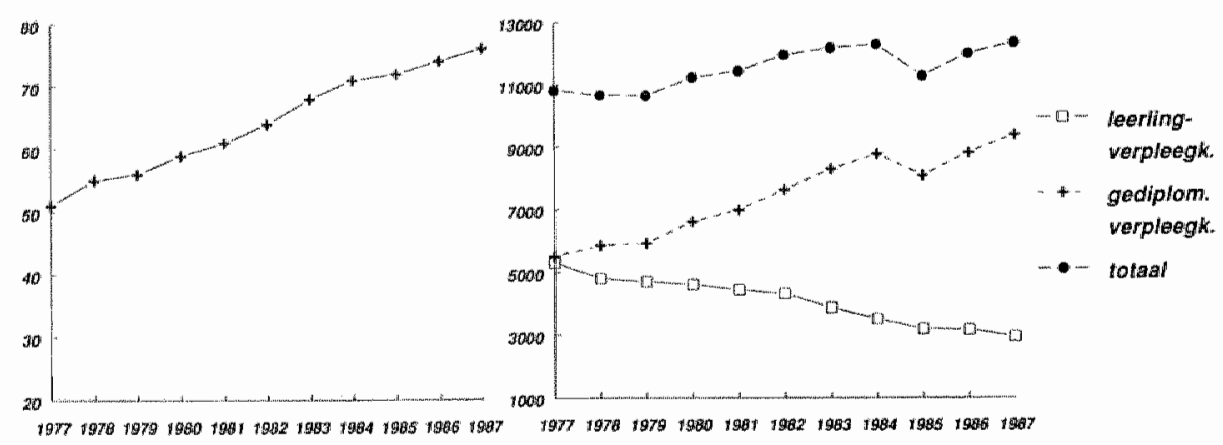

(Bron: N.Z.I., Statistiek personeelssterkte, resp. 1978 t/m 1988)

Figuur 1.1. Aantallen psychiatrisch verpleegkundigen

Aan het begin van deze paragraaf werd wermeld dat één van redenen voor oprichting van een opleiding het grote verloop onder het personeel was. Al gauw werd duidelijk dat dit niet de oplossing van dit personeelsprobleem bleek te zijn (Vijselaar, 1982). Aan B-verpleegkundigen is nagenoeg altijd een tekort geweest. Tussen 1953 en 1957 deed zich een stijging voor van een tekort van $4 \%$ tot $19 \%$. Het tekort aan verplegers was daarbij aanzienlijk lager dan dat een verpleegsters. In de vijftiger jaren was er zelfs een aparte beroepskracht, in de persoon van Zr. Meyboom, aangesteld om voorlichting te geven over de B-opleiding, met als doel het werven van verpleegsters (Meyboom, 1952). In 1967 werkten er in Heiloo 28 gediplomeerden op 700 patiënten. Volgens de geldende normen was dat een tekort van $40 \%$ (Binneveld en Wolf, 1985). 
De aanleiding tot het instellen van de opleidingen tot psychiatrisch verpleegkundige was gelegen in zowel een kwalitatief als kwantitatief tekort aan personeel. Het tekort aan verplegenden is door de opleiding nooit echt opgelost. De inhoud van de opleiding is voortdurend aan wijzigingen onderhevig. Een gunstige bijkomstigheid van de organisatievorm van de opleidingen als in-service opleiding is dat de inhoud ervan af kan worden gestemd op de taken van de verpleegkundigen. Het veranderen van die taken leidt tot aanpassingen van de opleiding.

Hoe de taken aan verandering onderhevig waren (en zijn) zal in de volgende paragraaf aan bod komen.

\subsection{Taken van psychiatrisch verpleegkundigen}

In de vorige paragraaf werd de bedverpleging reeds genoemd als een van de gevolgen van de vernieuwde inzichten in de behandeling van geestes- en zenuwzieken. De badverpleging werd eveneens ingevoerd. Deze zogenaamde permanente badbehandeling werd vooral toegepast op onrustige patiënten, vanwege de kalmerende werking die uit zou gaan van de lauwe baden. Ook werden patiënten behandeld door hen in te wikkelen in doeken. Deze behandelingen, de bad- en inwikkeltherapie, leken meer op dwangmiddelen dan op 'vrije verpleging' (Van der Meij-De Leur, 1974). Het uitgangspunt van het no-restraint beleid was namelijk om de patiënten zo min mogelijk te beperken in hun doen en laten op de afdelingen. Als noodzakelijk kwaad binnen de no-restraint opvattingen werd het gebruik van bad en inwikkelbehandeling gezien als een verbetering ten opzichte van de opsluiting in cellen (Schut, 1970). Het moge duidelijk zijn dat de uitvoering van de bad- en inwikkeltherapieën tot de taken van de verplegenden behoorden.

In 1926 werd door Hermann Simon te Gütersloh de aktievere therapie ingevoerd. Deze therapie werd ontdekt toen men genoodzaakt was ten gevolge van een tekort aan personeel de patiënten in te zetten bij werkzaamheden in de inrichting (Van der Meij-De Leur, 1974). Van der Scheer, geneesheer direkteur van het Provinciaal Ziekenhuis te Santpoort, introduceerde de aktievere therapie in Nederland. Het bellang van deze vorm van therapie is dat men niet meer het ziekelijke, doch de nog gezonde krachten en bekwaamheden van de zieke als aangrijpingspunt ter behandeling nam (Kramer, 1969).

Ook bij de aktievere therapie werden verplegenden ingezet, enwel met name wat meer ervaren verplegenden die daar belangstelling voor hadden (Poot, 1985).

Was er eerst dus sprake van oppassen en bewaken, later kwam het aksent te liggen op het verzorgen (met name in de betekenis van lichamelijke verzorging) en het deelnemen aan de arbeids- en bezigheidstherapie. Weer later, met de opkomst van de resocialiseringsgedachte wordt de verpleegkundige de centrale spil in het scheppen 
van een therapeutisch klimaat (Rozendal, 1981).

Deze ontwikkeling wordt in talrijke publikaties, o.a. onder een noemer als "van oppasser tot (socio-)therapeut" beschreven (Hopman, 1980). Dit geldt niet uitsluitend voor de Nederlandse situatie. Ook in de Angelsaksische literatuur worden publikaties aangetroffen van gelijke strekking (zie bijvoorbeeld: Bowling, 1974; Peplau, 1978; Darcy, 1978; Wondrak, 1982; Church, 1987). Al deze artikelen geven aan dat het beroep van psychiatrisch verpleegkundige ontstond uit de funktie van oppasser en leidde tot begeleider en therapeut.

Opmerkelijk is de parallel tussen de funkties van de psychiatrische instellingen en de taken van de daar werkzame verpleegkundigen. Immers ook de ontwikkeling van de psychiatrische centra kan omschreven worden als een: "van bewaken tot behandelen en begeleiden". Voor de psychiatrische verpleging is sprake van een afgeleide funktie. Tot nu toe is die funktie slechts in globale termen besproken. Hiernavolgend zal meer konkreet in onderdelen aandacht besteed worden aan de inhoud van de taken van de verplegenden.

In de periode 1880 - 1900 zagen de taken van de oppassers en oppasseressen er als volgt uit:

schoonmaken der vertrekken;

aandacht voor lichamelijke hygiëne;

verzorgen van de maaltijden;

orde handhaven en ontvluchtingen voorkomen;

dwangmiddelen toepassen.

(Bambang Oetomo, 1970; blz. 38)

Na 1900 kwam het aksent, naast de bewakende funktie, te liggen op de verpleging van de veelal in bed verblijvende patiënten. De dagelijkse bezigheden van de verplegenden bestonden uit:

patiènten helpen met handwerkjes;

het schoonmaken van het fruit;

met patiënten in de tuin wandelen, voor zover toegestaan;

patiënten catheteriseren/blaasspoelen;

het assisteren bij lumbaalpuncties;

bij onrustige patiënten helpen om een dwangjakje aan te doen;

bij ernstige onrust patiënten in natte lakens wikkelen;

het helpen van patiënten die permanente baden krijgen.

(Poot, 1985; blz. 1301) 
Tussen 1930 - 1960 werd de verpleging intensiever. Er was nu meer verpleegtechnisch werk ten gevolge van lichamelijke behandelwijzen zoals slaapkuren, insulinekuren, elektroshocks en andere behandelingsmethoden (Poot, 1985).

Pas met de invoering van psychofarmaca $\left.{ }^{6}\right)(1955$ - 1960) kon de funktie van 'oppassen en bewaken' op de achtergrond raken en kwam er tijd voor begeleiding en behandeling (Van der Laarse-De Bruin, 1981). De komst van de psychofarmaca was niet alleen van groot belang voor de behandeling van psychosen, maar had ook invloed op de taken van de verplegenden. Dat die invloed verder ging dan het afschaffen van de verplichte lessen in zelfverdediging uit de opleiding (die in sommige instellingen gegeven werden) blijkt uit het volgende citaat:

Toen er nog echte psychotici in de inrichting rondliepen met hallucinaties
en bloeiende wanen, waren er verplegers die op een bewonderenswaardige
wijze met dergelijke patiënten omgingen en met succes. In deze tijd vol
medicatie voelt dezelfde verpleger zich een soort consumentenbeurs voor
pilletjes, terwijl het echte 'werk' aan anderen wordt ovengedragen. (Smits, 1971; blz.420).

Vanaf de vijftiger jaren kwamen verpleegkundigen in de psychiatrische instellingen in een soort vacuüm terecht. Door de invoering van diverse therapieën ontstonden namelijk ook nieuwe disciplines, zoals de arbeids de bezigheids- en de bewegingstherapeuten. Maatschappelijk werkers, psychologen en pedagogen raakten eveneens bij de behandeling van de patiënten betrokken. De taken van de verplegenden stonden als het ware opnieuw ter diskussie. Ook van hen werd verwacht dat zij deel gingen nemen aan de therapeutische taken.

De moderne psychiatrische verpleegkundige behoorde óók een socio-therapeutische werker te zijn, nást de vele andere kapaciteiten waarover hij diende te beschikken, al naar gelang de omstandigheden (Cohen Stuart, 1965). "Het psychiatrisch verplegen", aldus Lutters en Smits in 1968, "zal in de toekomst veel meer het karakter krijgen van een persoonlijke begeleiding van de kant van de verpleegster en verpleger in het psychosociale revalidatieproces van de geesteszieken". De bekwaamheid: van de psychiatrische verpleegkundige kwam dus te liggen op het terrein van het hanteren van de menselijke verhoudingen (Van Beers, 1972). Dit betekende everwel niet dat oude taken vervielen.

Kramer (1970) verdeelde de taken van de psychiatrisch verplegenden in een drietal aspekten:

6) In 1952 werd Largactil (chloorpromazine) voor het eerst toegepast op psychotici (Kuiper, 1975). Daarmee was bet eerste psychofarmacum een feit. 
- Het op de juiste wijze verzorgen van de patiënt in die gevallen, waarin hij dit niet of onvoldoende kan doen.

- Het de arts mogelijk maken de behandeling uit te woeren, zowel somaiisch als psychisch.

- Kennis hebben van die verpleegkundig-therapeutische aspecten die van belang zijn voor een doeltreffende beinvloeding en begeleiding van psychiatrische patiënten.

(Kramer, 1970; blz. 42)

Het eerste aspekt slaat op de verzorging van de patiënten. Het tweede aspekt geeft de positie ten opzichte van de arts aan. Het laatste aspekt geeft de therapeutische taken van de psychiatrisch verpleegkundigen weer.

In publikaties van recenter datum wordt aan de omschrijving van Kramer vooral het groepswerk toegevoegd. $\mathrm{Er}$ is namelijk een verschuiving merkbaar van individuele zorgverlening naar groepsgerichte zorgverlening. Dit komt onder andere tot uitdrukking in de omschrijving van de Nationale Raad voor de Volksgezondheid. Door de Raad is een aantal rapporten uitgebracht over de specialisaties in de verpleegkunde. In het rapport dat een profiel schetst van de psychiatrisch verpleegkundige wordt deze beschreven als:
(...) iemand, die middels de creatie van een sociotherapeutisch leefklimaat en door individuele en groepsbegeleiding, bijdraagt aan de genezing en resocialisatie van de patiënten.

(N.R.V., 1983)

Een gedetailleerde uitwerking van de taken van psychiatrisch verpleegkundigen wordt gegeven door de Nationale Ziekenhuisraad:

- Coördinatie van patiëntgerichte aktiviteiten van de verschillende zorgverleners/behandelaars; bewaken van de uitvoering van het behandelplan.

- Individuele begeleiding van patiënten.

- Begeleiding van woongroepen, in stand houden van het juiste woonklimaat.

- Het leiden van diverse groepsaktiviteiten.

- Gerichte gedragsbeinvloeding in samenhang met door het behandelteam ontwikkelde programma's.

- Observatie en rapportage.

- Voor verpleegkundigen specifieke taken als:

beheer en verstrekken van medicijnen, verpleegtechnische handelingen e.d.

- Huishoudelijk werk: al het huishoudelijk werk dat samen met de patiënten wordt verricht, dan wel in direkte samenhang met andere zorg voor patienten plaatsvindt. 
- Bijvoorbeeld: samen met de patiënten verzorgen van maaltijden, koffie, thee, schoonmaken, wanneer een patient eten genorst heeft ed.

- Het in verband met psychische en/of lichanelijke invaliditeit ondersteinten en/of overnemen van $A D L$-aktiviteiten van patiënten.

(Schuring e.a., 1984, deel I; blz. 11-12)

Een vergelijking van de taken, zoals die hierboven weergegeven zijn, met die van de oppassers en oppasseressen van honderd jaar geleden laat zien dat er heel wat toegevoegd is. De oorspronkelijke taken, zoals huishoudelijk werk, aandacht voor hygiëne en het handhaven van orde worden overigens nog steeds aangetroffen, zij

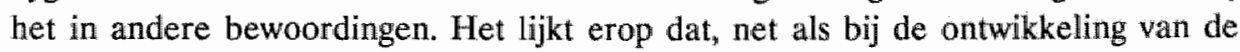
gestichten, sprake is van doeltoevoegingen, zoals die beschreven zijn door Bambang Oetomo (1974). Het doel van de gestichten was aanvankelijk bewaken en bedwingen van gestoorden. De lichamelijke zorgverlening kwam daar als doeloriëntatie bij. Later kwam daar de resocialisatie of begeleiding bij als doeloriëntatie. Het toevoegen van doelen aan de psychiatrische centra leidt tot het toevoegen van taken aan de verpleegkundigen. De realisatie van de doelen gebeurt immers door de verplegenden. De onderhavige verandering bestaat overigens niet alleen in het toevoegen van taken, maar ook in het verleggen van aksenten. Zo wordt in de leerstofomschrijving voor de vernieuwde B-opleiding van 1975 genoemd dat de verpleegkundige minder diagnostisch en meer therapeutisch gericht bezig moet zijn (Leerstof Ziekenverpleging-B, 1974).

Naast het verleggen van aksenten van individu naar groepsgericht werken, en van diagnostisch naar therapeutisch bezig zijn, kwam ook het aksent te liggen op de methodische aanpak. Dit laatste komt vooral tot uitdrukking in de definitie die Kerstens (1983) geeft van psychiatrische verpleegkunde: ${ }^{7}$ )

Psychiatrische verpleegkunde is het methodische hulpverleningsproces, waarbij de psychiatrische verpleegkundige als lid van het multidisciplinaire team een integraal begeleidingsproces ontwikkelt waarin hij het intermenselijk kontakt hanteert als een therapeutische relatie en de sfeer rondom dat intermenselijke contact uitbouwt tot een therapeutisch milieu teneinde de 'zieke' mens te begeleiden van een afhankelijke naar een onafhankelijke relatie/situatie.

(Kerstens, 1983; blz. 159).

Voor de uitleg van deze definitie zal gebruik gemaakt worden van de toelichting die de auteur er zelf bij geeft. Psychiatrische verpleegkunde wordt gezien als een metho-

${ }^{7}$ Bij de herziening van het opleidingsleerplan woor de B-opleiding heefi het werk wan Kerstens naast de indeling van Van den Brink-Tjebbes een belangrijke rol gespeeld. 
disch hulpverleningsproces. Dit will zeggen dat er sprake is van doelgericht, bewust, systematisch en procesmatig handelen. De verpleegkundige werkt daarbij in een team dat bestaat uit verschillende disciplines. De patiënt - verpleegkundige relatie is therapeutisch als de verpleegkundige in relatie met de patiënt mogelijkheden kreëert waardoor de patiënt zelf, binnen zijn mogelijkheden en beperkingen, tot een oplossing kan komen van zijn problemen. Met therapeutisch milieu wordt bedoeld dat sprake is van een georganiseerde behandelingseenheid, waarbinnen én patiênt relaties met een groep en behandelaars worden aangeboden.

Ontstond het beroep van psychiatrisch verpleegkundige uit de funktie van oppasser en bewaker, die naast de arts verantwoordelijk was voor de zorg voor de psychiatrische patiënt, tegenwoordig is de psychiatrisch verpleegkundige alls lid van het multidisciplinaire team ook therapeutisch aktief. De primaire verzorgende taken zijn daarbij nog steeds aanwezig. Deze kombinatie van nieuwe en oude taken vormt de basis voor menige diskussie over de rol van de psychiatrisch verpleegkundige, zoals zal blijken uit de volgende paragraaf.

\subsection{Beroepsidentiteit van de psychiatrisch verpleegkundige}

Bij de bespreking van de taken in de vorige paragraaf werd reeds duidelijk dat de psychiatrisch verpleegkundige steeds meer (ook) een therapeutische taak kreeg. Die verandering hing samen met de ontwikkeling van de psychiatrische instellingen, die eveneens tot uitdrukking kwam in de verandering van de samenstelling van het personeell. Waren er eerst de zenuwarts en de verplegenden, daarna kwam er een leger van gespecialiseerde deskundigen die de patiënten in teamverband behandelden. Verplegenden werden daarbij nauwelijks meer nodig geacht (Esser, 1956). De verplegenden wier taken nu, door de afname van verpleegtechnisch werk, steeds minder op die van de ziekenhuisverpleegkundigen gingen lijken, gingen zich daarvan ook in uiterlijke herkenning onderscheiden door het niet meer dragen van de uniformen (witte jassen).

Naast thet vervallen van een deel van de verpleegtechnische taken, werden ook taken van de verpleegkundigen overgenomen door nieuwe disciplines, zoals de arbeidstherapeuten en de maatschappelijk werkers.

De psychiatrisch verpleegkundige kreeg langzaam maar zeker meer te maken met allerlei sociale problematiek variërend van huwelijks- en seksuele tot opvoedings- en drugsproblemen. Daarbij funktioneert de psychiatrisch verpleegkundige tussen genees en gedragskundigen (Vermaas, 1974). Het gevolg van dit alles was dat verplegenden gekonfronteerd raakten met onduidelijkheden omtrent hun beroepsidentiteit (De Wit, 1975). De vraag speelde of 'verplegers' nog wel de juiste aanduiding van het beroep was en of die wellicht beter vervangen kon worden door 'therapeuten' of 'groepslei- 
ders' (Jacobs, 1968). Kern van die diskussie rond de beroepsidentiteit is de vraag of de psychiatrisch verpleegkundige primair de rol van begeleider van de patiënten bij alledaagse zaken dient te vervullen of ook een rol als therapeut bij de behandeling heeft. Men dient een keus te maken tussen de B-verpleegkundige die een 'behandelaar' van het leefmilieu van de patiënt is, maar geen therapeut of de B-verpleegkundige die juist of zelfs voornamelijk funktioneert als individuele en/of groepstherapeut (Van Ree, 1975). Volgens Van Ree verdient het tweede alternatief de voorkeur. De meningen daarover zijn evenwel niet eensluidend. Volgens Ganzevoort (1973) is het niet verstandig om te streven naar een verregaande (agogische) bijscholing voor verpleegkundigen. Het typische van het 'verpleegkundige-zijn' zou daarmee ondermijnd worden.

De geest was echter al uit de fles. Er werden applikatiekursussen opgezet voor afgestudeerde B-verpleegkundigen. Voorbeelden daarvan zijn een kursus "werken met de groep als behandelingsinstrument' en een kursus 'groepsverpleegkundige' bestaande uit onder andere een aantal agogische vakken (Bras, 1977). Met die nascholingskursussen wordt gereageerd op de noodzaak tot het bezitten van vaardigheden voor het werken in groepen. Volgens Stolte (1981) komt daarmee de rechtstreekse relatie van de verpleegkundige tot de individuele patiënt, en daarmee de eigenheid van de professie, in het gedrang.

Groepsverpleging ${ }^{8}$ ) en sociotherapie leken de psychiatrisch verpleegkundige een nieuwe identiteit te geven. Vooral de aanduiding sociotherapeut werd regelmatig gebruikt. Het werd daarom zelfs noodzakelijk geacht om een nadere studie van het verschijnsel sociotherapeut te maken. De kommissie die daartoe in 1976 opgericht werd, kreeg als opdracht om te onderzoeken wat de identiteit van de sociotherapeut was en welke rol deze in de psychiatrische hulpverlening kon hebben. De kommissie kwam tot de konklusie dat sociotherapeut geen beroep was, maar een funktie. Voor de uitoefening van sociotherapie zou een hogere specifieke funktie-opleiding nodig zijn (Blaauw en De Weger, 1986).

Opmerkelijk is de overeenkomst tussen de definitie van psychiatrische verpleegkunde van Kerstens (zie vorige paragraaf) en de definitie van sociotherapeut die door de kommissie gegeven werd:

Een sociotherapeut is een gekwalificeerde funktionaris op het gebied van het methodisch hanteren van het leefklimaat.

(Commissie Sociotherapie,1982)

8) Dit begrip wordt nogal eens verward met teamverpleging. Bij groepswerplleging gat het ook om het hanteren van de groep en groepsprocessen als middel in de behandeling. Bij tearnverpleging worden patiënten en werpleegkundigen wel in groepen verdeeld, doch is de groep geen medium in de behandeling. 
In beide definities stat als het ware het methodische aspekt en het hanteren van het leefklimaat, c.q. therapeutisch milieu centraal.

Volgens Mertens (1985) dient sociotherapie gezien te worden als een nadere invulling van het funktioneren van de verpleegkundige in de psychiatrie. De auteur gaat daarbij nog verder door te stellen dat sociotherapie een verpleegkundig behandelingsmodel is. De Nationale Raad voor de Volksgezondheid is van mening dat sociotherapie geen specialisatie is, doch als onderdeel van het opleidingsleerplan B-verpleegkundige opgenomen moet worden. Deze opvatting strookt met de omschrijving die Dörner geeft van sociotherapie:

\section{Soziotherapie ist die Basis therapeutischen Handelns in psychiatrischen Einrichtungen.}

(Dörner, 1978; blz.351)

Hoewel de sociotherapie beschouwd kan worden als een onderdeel van de taken van psychiatrisch verpleegkundigen, vormt deze behandelvorm een bedreiging van de beroepsidentiteit van de verpleegkundigen. Voor het uitoefenen van de funktie van sociotherapeut is namelijk geen diploma ziekenverpleging vereist is. Zo wordt in personeelsadvertenties voor een sociotherapeut veellal iemand gevraagd die in het bezit in van hetzij een diploma ziekenverpleging-B, hetzij een diploma inrichtingswerk. Vooral die laatste kategorie, de inrichtingswerkers ${ }^{9}$ ) vormen in deze een potentiële vervanging van de psychiatrisch verpleegkundigen.

Inrichtingswerkers zijn primair opgeleid voor het werken met groepen. Hun opleiding, verzorgd door de sociale akademies, kan beschouwd worden als een logisch vervolg op (en zelfs als een alternatief voor) de B-opleiding. Diverse psychiatrische instellingen geven B-verpleegkundigen de gelegenheid deze opleiding (gedeeltelijk) in werktijd te volgen. In sommige instellingen werken inrichtingswerkers samen met verpleegkundigen op de afdelingen. Andere instellingen laten inrichtingswerkers alleen toe, wanneer deze eveneens over een B-diploma beschikken. In de praktijk werken psychiatrisch verpleegkundigen, inrichtingswerkers en personen die beide opleidingen gevolgd hebben op dezelfde afdelingen in vergelijkbare en zelfs gelijke funkties.

De diskussie over de beroepsidentiteit gaat voort tot de dag van vandaag, zoals blijkt uit een recente publikatie in het Tijdschrift voor Ziekenverpleging. Alleen al de titel

9) Voor alle duidelijkheid dient hier vermeld te worden dat 'inrichtingswerkers' de aanduiding is van diegenen die in het bezit zijn van een middelbare of hogere beroepsopleiding inrichtingswerk. De term zou tot verwarring kunnen leiden, aangezien strikt genomen iedereen die werkzaam is in een inrichting als inrichtingswerker beschouwd kan worden. 
ervan spreekt boekdelen: "Werken er nog verpleegkundigen in de psychiatrie?" (Van Dam, e.a. 1987).

De kern van die diskussie is (nog steeds) de vraag of de psychiatrisch verpleegkundige primair een verpleegkundige, danwel een therapeutische rol vervult.

\subsection{Algemene ontwikkelingen in de verpleegkunde die van invloed zijn op de psychiatrische verpleging}

Tot nu toe is gesproken over de veranderingen in de psychiatrische verpleging vanuit ontwikkelingen in de psychiatrische instellingen. De psychiatrische verpleegkunde maakt echter deel uit van het verpleegkundig beroep. Ook ontwikkelingen in de verpleegkunde in het algemeen zijn derhalve van invloed op het beroep van psychiatrisch verpleegkundige. Van belang is in dit verband vooral de professionalisering van de verpleegkunde. Funktiegerichte scholing in de diverse instellingstypen zoals die in de verpleging plaatsvinden vormen daarbij een eerste struikelblok. Professionalisering wordt namelijk belemmerd bij beroepen die in hun funktie uitoefening afhankelijk zijn van organisaties, zoals bijvoorbeeld ziekenhuizen (Freidson, 1981), die de taken van de betreffende funkties bepalen. Dit had tot gevolg dat de invulling van deze funktie van de verpleegkundige in het algemeen ziekenhuis, de psychiatrische instellingen en in de overige werkvelden onafhankelijk van elkaar ontwikkelde. De wens tot eenheid in het verpleegkundig beroep is daarmee een belangrijke voorwaarde voor de professionalisering geworden. Dit leidde uiteindelijk tot de oprichting van schoolopleidingen, die onafhankelijk van de ziekenhuizen moesten funktioneren en op den duur in de plaats zouden komen van de (funktiegerichte) in-service opleidingen. Het betreft opleidingen op middelbaar en hoger beroepsopleidend niveau. Deze opleidingen gingen in 1972 van start bij de toenmalige Hogere Scholen voor Verpleegkundigen, het Seminarium voor Gezondheidszorg te Utrecht, en de Katholieke Hogere School voor Verpleegkundigen te Nijmegen. Bij deze opleildingen werd uitgegaan van één geïntegreerd programma waarin die grondbegrippen, vaardigheden en attitudes ontwikkeld dienden te worden die de grondslag vormen van elke vorm van verplegen (De Hey, 1979). Uitgangspunt was daarbij dat verplegen een ondeelbaar beroep zou zijn. In de uitoefeningen daarvan (bijvoorbeeld in ziekenhuizen of psychiatrische instellingen) zouden slechts aksentverschillen zijn. Deze werden evenwel niet spectaculair geacht. Wel werd gesteld dat er duidelijke aksentverschillen in de funktieprofielen van verpleegkundigen zouden zijn. De scholing kreeg al naar gelang de sektor een aksent op een meer somatisch-technische, danwel agogisch-technische vaardigheden (De Jong, 1982). Thiadens formuleerde dit in 1971 als volgt: 
De accentuering wan de verpleegkundige $A$ ten aanzien wan de verpleegkandige $B$ en $Z$ mag alleen gehanteerd worden vanuit het instituut en niet vanuit de professie. Immers, de specifieke accentuering van de verpleegkundige $A, B$ of $Z$ geeft een uitholling van het beroepsbeeld te zien. ${ }^{19}$ ) (Thiadens ê.a., 1971; blz. 133)

In deze periode ( \pm 1970 tot heden) lopen dus twee ontwikkelingen naast elkaar. Enerzijds is er een professionaliseringsproces; anderzijds is er in de B-opleiding sprake van het verleggen van aksenten naar de meer agogisch gerichte benadering (sociotherapie), welke de indruk geeft dat de psychiatrische verpleging steeds meer afstand neemt van het verpleegkundig beroep. De nadruk op een meer agogische benadering kwam in 1975 tot uitdrukking bij de herziening van de B-opleiding door het witbreiden van het vakkenpakket met andragogie en persoonlijkheidsvorming. Het vak verpleegkunde was tot 1986 in de B-opleiding opgedeeld in somatische en psychiatrische verpleegkunde. Beide vakken waren verplicht. In de A-opleiding was psychiatrische verpleegkunde een fakultatief eksamenvak. De dagopleidingen gaan uit van verpleegkunde als eén vak.

In essentie bestaat het verschil tussen de dagopleidingen en de in-service opleidingen daaruit dat er in het eerste geval sprake is van beroepsopleidingen en in het tweede geval van funktie-opleidingen.

Vermaas (1980) ageerde tegen deze nieuwe ontwikkelingen in de verpleging, die er volgens hem toe zouden leiden dat het vakgebied psychiatrische verpleegkunde zou verdwijnen. Zijn voorspelling is uitgekomen. Bij de laatste herziening van de B-opleiding in 1986 is dit vak namelijk niet meer opgenomen in het opleidingsleerplan. Psychiatrische verpleegkunde wordt merkwaardig genoeg alleen nog onderwezen in de A-opleiding (Giebing, 1986). Wel kent de B-opleiding als thema onderdeel van het vak verpleegkunde de zogenaamde specifieke verpleegkunde. Onder die noemer wordt dan aangetroffen wat eerder als psychiatrische verpleegkunde aangeduid werd.

De drang naar eenheid in het verpleegkundig beroep, welke vorm krijgt in de schoolopleidingen lijkt daarmee de diskussie rond de identiteit van de psychiatrisch verpleegkundige eerder te versterken dan op te lossen.

10) Z stat voor zwakzinnigenzorg. Deze opleiding is sinds 1978 (met terugwerkende kracht) erkend als verpleegkundige opleiding. Om de eenheid in het verpleegkundige beroep te benadrukken werd ook het aparte insigne voor de A-en B-verpleging afgeschaft. Alle verpleegkundigen (A, B,

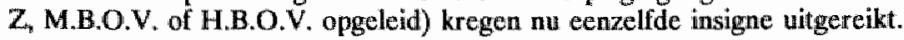




\subsection{De zorg voor de chronische psychiatrische patient}

Tot 1904 was de vrijwillige opname in een gesticht ommogelijk. Een Rechterlijke Machtiging of een In Bewaring Stelling, waarmee de patiënten opgenomen werden, maakte het nodig om de afdelingen zorgvuldig op slot te houden, teneinde ontsnapping van de patiënten te voorkomen (Bakker - Van der Kooij, 1984). In 1914 werden voor het eerst de zogenaamde 'open afdelingen' ingevoerd (Dane, 1968). Sindsdien konden de patiënten onderverdeeld worden in twee kategorieën: zij die op gesloten afdelingen verpleegd werden en zij die op open afdelingen verpleegd werden. Geleidelijk aan ging men inzien dat behandeling en verpleging van psychiatrische patiènten zeer nauw met elkaar verbonden waren (Esser, 1956). De voorkeur ontstond om patiëntengroepen te formeren naar aard en ernst van medische en verpleegkundige problemen, en niet langer op basis van de wijze van opneming, te weten gedwongen of vrijwillig (Cohen Stuart, 1966).

Uiteindelijk leidden deze inzichten tot het verplegen van patiënten met gelijksoortige zorgvragen op dezelfde afdelingen. Het gevolg was daarvan weer dat men ging differentiëren en meer zicht kreeg op de populatie die in de inrichtingen verbleef. Zo ontstond de afsplitsing van de zorg voor zwakzinnigen en (deels) van de zorg voor ouderen die lijden aan dementie. Voor het psychiatrisch centrum bleef over de behandeling van psycho-sociale problemen en de verpleging van patiënten die al lange tijd in de inrichtingen verbleven. Er vond een indeling plaats in de zogenaamde shortstay en longstay-psychiatrie (Van Andel, 1980).

Het langdurig verblijf vam bepaalde groepen patiënten in de inrichtingen zag men steeds meer als een gevolg van het ontbreken van de juiste behandelingsmethoden in het verleden. Het aantal langdurig opgenomen patiënten zou vanzelf afnemen door het gebruik van de moderne behandelingsmethoden, zoals die ook in de shortstay aangewend werden. Een beperkte groep die toch permanent begeleiding nodig zou hebben, diende in kleinschalige woonvoorzieningen gehuisvest te worden. $\mathrm{Na}$ verloop van tijd zouden de grootschalige psychiatrische inrichtingen dan vervangen kunnen worden door kleine behandelcentra. Althans zo waren de beleidsvisies in de jaren zeventig. Uitgangspunt daarbij was de gedachte dat de institutionalisering van de hulpverlening, in de vorm van psychiatrische inrichtingen, een mogelijk faktor was die de zorgbehoefte zou stimuleren (Barton, 1966; Ciompi, 1980). De woonfunktie van de psychiatrische centra zou, voor zover toch nodig, op geheel andere wijze worm moeten krijgen (De Haen, 1981). De uitwerking van die visies leidde er uiteinndelijk toe, dat men zich meer en meer ging afvragen wie die chronische psychiatrische patiënten waren; of abstracter geformuleerd: "Wat is chroniciteit eigenlijk?" (Goldman, 1981).

Het begrip chroniciteit/chronische patiënt wordt in verschillende betekenissen gebruikt. Wat men eronder verstaat is veelal afhankelijk van de reden waarom die 
groep personen omschrijving behoeft (Giel, 1984). Dit verklaart dat sommige auteurs stellen dat het een meerduidig begrip is, dat meer verwarring dan helderheid brengt (Gersons, 1984; Holman, 1985). Deze verwarring is deels terug te voeren tot het gelijk stellen van chroniciteit aan opnameduur en frekwentie van opname. De diskussie spitst zich dan toe op de duur van de opname: hoelang is langdurig en na hoeveel tijd raakt iemand chronisch? Anders gezegd: in welke mate neemt de kans op ontslag af, naarmate iemand langer opgenomen is (Offerhaus, 1983).

In de literatuur over de chronische psychiatrische patiënt ligt de nadruk op twee problemen: enerzijds het beleidsprobleem, waar en hoe de chronische patiënten een plaats in de maatschappij te geven; anderzijds de verklaringsproblemen omtrent oorzaken van chroniciteit. Wat dit laatste betreft zijn er in grote lijnen twee stromingen te benoemen: de verklaring van chroniciteit vanuit omgevingsfaktoren na opname en die vanuit persoonsgebonden faktoren, welke reeds voor opname in de inrichting aanwezig zijn en aanleiding zijn tot de opname zelf (Van den Hout, 1985).

Voor beide benaderingen zijn argumenten aan te dragen. Ciompi (1980) heeft in een overzichtsartikel over chroniciteit deze argumenten afgewogen. Hij konkludeert dat chroniciteit het beste beschouwd kan worden als een hospitalisatie-artefakt. Er zou sprake zijn van psychosociale problemen, die leiden tot een acute hulpvraag. Het falen van de hulpverlening in het oplossen van die problemen leidt dan tot chroniciteit. Barton (1966) was, geïnspireerd door het werk van Goffman, een van de aanhangers van deze benadering van chroniciteit. Wing en Braun (1970) plaatsten een aantal kanttekeningen bij de hospitalisatiethese van Barton. Wing bleef zich tegen deze, volgens hem eenzijdige benadering, verzetten. Eind zeventiger jaren konstateerde Wing dat, ondanks het nieuwe beleid (de-institutionalisering) alle veranderingen niet leidden tot een afname van het aantal chronische patiënten (Wing, 1978).

Ook in Nederland heeft de de-institutionalisering niet geleid tot afname van het aantal chronische patiënten. Het aantal neemt de laatste jaren zelfs toe (N.c.G.v., 1987). Haveman (1984) spreekt daarom van trans-institutionalisering. De chronische patiënten zijn er nog steeds, doch nu ondergebracht in andere voorzieningen. Dit betekent niet, dat er geen veranderingen plaatsvonden in de aard van de behandeling. Het is immers juist de woonfunktie die op andere wijze vorm heeft gekregen (Delimon, 1980). Daar waar het begrip chronische patiënt vervangen wordt door 'bewoner' impliceert dit, dat deze mensen niet 'in behandeling' zijn, doch 'in zorg'. Anders gezegd: het gaat niet om een therapeutisch model, maar om een invaliditeitsmodel (De Jong, 1984). In deze benadering gaat men niet zozeer uit van de vraag wat de oorzaken van chroniciteit zijn, doch van de aktuele hulpvraag: de behoefte aan een beschermd woonmilieu van de patiënt. Vooral Wing en Braun (1970) hebben zich sterk gemaakt voor deze benadering die als het ware een integratie beoogt van de klinische en de sociale inzichten in de problematiek van de chronische patiënt. De 
oorzaken van chroniciteit worden volgens Wing niet verklaard als of ziekte of gevolg van langdurige opname, doch eerder uit een kombinatie van beide faktoren. Bij chroniciteit gaat het dan om sociale handicaps in de zin van:

(...) the state of an individual who is unable to perform socially up tot the standards expected by himself or herself, by people important to him or her, or by society in general.

(Wing \& Morris, 1981; blz. 4)

In bovenstaande beschrijving van het definitieprobleem van de chronische psychiatrische patiënt, staan twee benaderingen centraal: de ziektethese en de hospitalisatiethese. In het eerste geval gaat het om het beschouwen van chroniciteit als ziekte, in het tweede geval gaat het om de hospitalisatie-processen, zoals beschreven door Goffman (1961) en Barton (1966). Laatst genoemde processen zouden leiden tot hospitalisatie-effekten, met betrekking tot de relatie tussen het milieu van de inrichting en het gedrag van de patiënt (Wennink, 1986). Een derde benadering die een integratie vormt van deze twee thesen is de handicapthese, die aansluit bij de theorie van Wing. Daarbij gaat het niet zozeer om de oorzaken van chroniciteit, doch om het aktuele gedrag van de patiënten. Voor verpleegkundigen is met name deze benadering van belang. Immers de aktuele hulpvraag en niet de oorzaken van chroniciteit bepaalt de taken van de verpleegkundigen.

\subsection{De verpleegkundige als begeleider van de chronische patiënt}

Psychiatrisch verpleegkundigen zijn van oudsher de begeleiders van psychiatrische patiënten in de inrichtingen, ook van de chronische patiënten. Zij worden daarmee gezien als een van de faktoren van het inrichtingsmilieu die van invloed zijn op het ontstaan van hospitalisatie-effekten.

In 1973 wordt door de Visiekommissie van psychiatrisch centrum St.Bavo het Tweede Visierapport uitgebracht onder de titel "De chronische patiënt". In het kader van de zorg voor chronische patiënten wordt ferm kritiek geleverd op de verpleegkundige discipline. De nadruk ligt daarbij op het kwallitatieve tekort van de verpleging. Gekonstateerd wordt dat de opleiding tekortschiet. De hele gang van zaken in de opleiding wordt als anti-therapeutisch bestempeld:

Men leert er zogenaamde interessante psychiatrische en psychologische wederwaardigheden. Diagnoses die (...) in de psychiatrische inrichting van weinig waarde zijn.

(St. Bavo, 1973; b»z.163) 
De houding die men aanleert in de opleiding is te veel verzorgend en te weinig begeleidend. Let wel, we schrijwen 1973. Sindsdien is 0.a. door de herziening van de $\mathrm{B}$-opleiding in 1975 meer nadruk gelegd op persoonlijkheidsvorming en agogische technieken. Profijt daarvan hebben met name verpleegkundigen die op behandelafdelingen en therapeutische gemeenschappen werken. Voor verpleegkundigen die bij chronische patienten werken gaat het namelik om ander zaken. Een paradoxale komplikatie voor verpleegkundigen is dat zij geacht worden om een deel van de vertrouwde taken af te stoten; ze moeten afleren wat ze gewend waren te doen. Holman en Wennink (1986) spreken in dit verband over de vier $A$ 's in het begeleiderswerk. Het gaat daarbij om 'attitude-verandering', 'afwachten', 'accepteren' en "afleren". Bij attitude-verandering gaat het om het verwerven van een attitude die past bij de doelstelling van het wonen. Afwachten slaat op het voor lief nemen om niets te doen, en af te wachten tot de initiatieven van de bewoners zelf komen. Accepteren heeft betrekking op de acceptatie van de normen en waarden van de bewoners, wastbij onderhandeling de basis is voor beinvloeding van het gedrag van de bewoner. Het belangrijkste voor de verpleegkundige is de vierde 'A' van afleren. Deze staat namelijk voor het afleren van datgene wat geleerd is in de opleiding: mensen die in de problemen zijn gekomen, efficiënt, snel en vriendelijk weer op het rechte spoor te zetten. De auteurs stellen dan ook dat verpleegkundigen moeten emanciperen van verpleegkundige naar begeleider. Onder begeleiden verstaan zij, in navolging wan Dröes:

- dat er sprake is van een deels persoonlijke, deels professionele relatie tussen begeleider en bewoner;

- dat er geen algemeen geldende termijndoelen zijn;

- dat niet systematisch gebruik gemaakt wordt van principes uit de groepstherapie, de saciotherapie of van verzorgende of verpleegkundige principes. (Drö́es, 1982; blz. 1181).

Het zijn vooral de twee laatste punten uit de omschrijwing van begeleiden waarmee de verpleegkunde in moeilijkheden raakt. In de tijd waarin verpleegkunde gezien wordt als een methodisch hulpverleningsproces, blijkt het voor de verpleging van de chronische psychiatrische patiënt, volgens sommigen althans, niet gewenst om doelen. en tijdslimieten te stellen en gebruik te maken van deze systematische principes. Behandeldoelen zouden geen uitgangspunt kunnen zijn voor de begeleiding in beschermende woonvormen (Holman, 1984).

Wat nu te doen met een uitspraak over verplegen en methodisch werken als de volgende: 
The nursing process is the core and essence of nutsing; it is central to all nursing actions; applicable in any setting, within ary frame of teference, any concept, theory, or philosophy.

(Yura \& Walsh, 1978; blz. 1).

Ook andere auteurs zijn die mening toegedaan. Zo benadrukken Keane (1981) en Stockwell (1985) dat zowel de algemene als de psychiatrische verpleging gebaat zijn met een methodische aanpak. Dezelfde mening wordt ook aangetroffen in een leerboek voor het toepassen van het verpleegkundig proces in de psychiatrische verpleegkunde (Ward, 1987).

De visie van Holman en Wennink op de rol van de verpleegkundige bij de begeleiding van chronische patiënten levert voor de verpleegkunde een dilemma op. De verpleging kan daarmee twee kanten uit: of zij erkent dat chronische psychiatrische patiënten niet gebaat zijn met verpleegkundigen als hulpverleners, òf zij erkent dat niet op alle terreinen van de verpleging een methodische aanpak essentieel is. Altschul (1978) opteert duidelijk voor de laatste aanpak. Zij stelt dat het van belang is om er niet zonder meer van uit te gaan dat het verpleegkundige proces in de psychiatrische verpleging altijd zinvol is toe te passen. Ook Houtepen (1986) wijst op de beperkingen van de toepassingsmogelijkheden van het systematisch verpleegkundige handelen wanneer het gaat om verpleegproblemen van psychosociale aard.

De meningen over de noodzaak tot methodisch werken in de psychiatrische verpleging zijn derhalve verdeeld. Daarbij dient niet over het hoofd gezien te worden dat de opvattingen over begeleiden, zoals door Holman \& Wennink (1986) beschreven, met name bedoeld zijn voor beschermende woonvormen. Dus daar waar 'wonen' en niet behandelen op de eerste plaats komt als doelstelling van de afdeling. De verpleegkundige die voor wat betreft het methodisch werken al te zuiver in de leer is verkeert op die afdelingen in een moeilijk parket. Nu niet vanwege het kwalitatieve tekort, zoals begin jaren zeventig, doch vanwege een 'kwalitatief teveet'. Begeleiders staan overgekwalificeerd in een zorgsysteem, dat ernaar streeft een zo-normaal-mogelijk-woonmilieu te zijn (Holman \& Wennink, 1986).

Bij de begeleiding van chronische patiënten ontstaat dus een doorbraak in de traditie waarmee de taken van de verpleegkundige tot stand kwamen. Was eerst sprake van uitbreiding van deze taken, afgeleid van de doeltoevoegingen van het psychiatrisch centrum, en het verleggen van aksenten waar door de opleidingen op ingespeeld werd, nu wordt gevraagd om deels af te leren wat in de opleidingen geleerd werd, en te emanciperen van verpleegkundige naar begeleider. 


\subsection{Vraagstellingen}

Uit de literatuurverkenning wordt duidelijk op welke manier ontwikkelingen in de geestelijke gezondheidzorg van inwloed zijn op het beroep wan psychiatrisch verpleegkundige. Vooral de taken van verpleegkundigen in de psychiatrische instellingen lijken onder invloed van die ontwikkelingen te veranderen. Een vraag daaromtrent blijft vooralsnog onbeantwoord: welke konkrete middelen wenden zij aan om het begeleidingsproces vorm te geven? Anders gesteld: waaruit bestaan de taken van psychiatrisch verpleegkundigen in de praktijk van alledag bij de zorg voor de chronische patiënt.

Het gevolg van de verandering in de taken van de verpleegkundige is een diskussie over de beroepsidentiteit van de psychiatrische verpleging. Dit leidt tot vragen omtrent de positie van psychiatrisch verpleegkundigen, zowel binnen de eigen beroepsgroep, als binnen het tegenwoordige multidisciplinaire team in de psychiatrische instelling.

Daar de spil in deze ontwilkelingen de veranderende visie op de zorg voor de chronische psychiatrische patiënt is, rijst de vraag naar de visie van psychiatrisch verpleegkundigen op de problematiek wan de chronische patiënt. Ter verkenning van de centrale probleemstelling die gericht is op de taakopvattingen van psychiatrisch verpleegkundigen, zullen eerst de hiervoor genoemde aandachtspunten nader vanuit de praktijk verkend worden.

\section{Samenvatting}

Uit een verkenning van de literatuur blijkt dat de psychiatrisch verpleegkundige beroepsgroep sinds jaar en dag een bijzondere plaats inneemt in het totaal van verpleegkundige beroepen. Uit de ontwikkeling van de taken van psychiatrisch verpleegkundigen wordt duidelijk dat er in de loop der tijd steeds nieuwe taken toegevoegd zijn. Tevens kunnen die taken gezien worden als een afgeleide van de funktie van de psychiatrische instellingen. Zo leidt het onderscheiden van behandel en verblijfspsychiatrie tot een tweedeling in de psychiatrische verpleegkunde. Enerzijds ontwikkelt de psychiatrisch verpleegkundige zich tot (socio-) therapeut; anderzijds tot begeleider. Beide rollen tasten de verpleegkundige identiteit aan. Met name de begeleidersrol van chronische psychiatrische patiënten lijkt in strijd met aktuele ontwikkelingen van de verpleegkunde: het methodisch werken. Dit neemt niet weg dat 'chroniciteit' met betrekking tot de psychiatrische patiënt gezien kan worden als een verpleegprobleem, waarbij psychiatrisch verpleegkundigen een taak in de begeleiding hebben. Hoe die taak in de dagelijkse praktijk gestalte krijgt wordt uit de literatuur niet duidelijk. Een verkennend onderzoek daarnaar is gewenst. In het volgende hoofdstuk wordt verslag gedaan van een dergelijke praktijkverkenning. 


\section{INTERVIEWS MET PSYCHIATRISCH VERPLEEGKUNDIGEN}

\section{Inleiding}

In dit hoofdstuk wordt verslag gedaan van een praktijkverkenning aan de hand van interviews, die gehouden werden met 52 verpleegkundigen uit vijf psychiatrische instellingen. Doelstelling daarvan was het verkrijgen van informatie over het beroep van psychiatrisch verpleegkundige. De literatuur over het beroep van psychiatrisch verpleegkundige, zoals beschreven in het vorige hoofdstuk, liet namelijk een aantal vragen onbeantwoord. De aandachtsgebieden zoals geformuleerd in het vorige hoofdstuk dienden bij de interviews als leidraad. Deze zijn weergegeven in de volgende vraagstellingen:

A. Welke taken verrichten psychiatrisch verpleegkundigen in de praktijk van alledag?

B. Hoe ervaren psychiatrisch verpleegkundigen hun positie als lid van het multidisciplinaire team binnen psychiatrische instellingen?

C. Welke plaats nemen psychiatrisch verpleegkundigen, naar hun mening, in binnen de verpleegkundige beroepsgroep?

D. Welke opvattingen hebben psychiatrisch verpleegkundigen over chronische patiënten?

\subsection{Werkwijze}

Voor het verkrijgen van antwoorden op de vraagstelling is gebruik gemaakt van semigestruktureerde interviews. De vragen daarvoor werden opgesteld rondom de vraagstellingen en werden zowel direkt als undirekt gesteld. Naast de vragen werd ook een casus aan de deelnemers voorgelegd. Deze diende ter aanvulling van de antwoorden op de open vragen. Tevens heeft een casus het voordeel dat iedereen naar aanleiding van eenzelfde situatie dient te reageren ").

De op tape opgenomen gesprekken werden beluisterd en woorzien van respondenten vraagnummer uitgewerkt op systeemkaarten. Per vraag is vervolgens nagegaan welk type informatie deze opleverde in relatie tot de oorspronkelijke vraagstellingen. Zo gaf bijvoorbeeld een vraag naar de ontwikkelingen in de psychiatrie, informatie over de huidige situatie ("toen was het zo..., nu is het zo....").".

1) In Bijlage A zijn de vragen van de interviews, alsmede de casus opgenomen. Ook wordt in de bijlage een verantwoording gegeven van de samenstelling van de steekproef voor de interviews. 
Voor het ordenen van het materiaal werd gebruik gemaakt van de door Spradley (1980) omschreven methode walarbij per uitspraak gezocht dient te worden naar een gemeenschappelijke noemer die dan een kategorie ter ordening van het materiaal aangeeft.

Om de persoonlijke invloed van de onderzoeker zo veel mogelijk te beperken zijn bij de verwerking van de interviews meer personen betrokken. Het beluisteren en uitwerken op systeemkaarten gebeurde door de onderzoeker zelf. De casus werd door lemand anders beluisterd en uitgewerkt. Het vaststellen van kategorieën aan de hand van de uitspraken vond in overleg plaats. Daarbij zijn de items ook ter beoordeling voorgelegd aan iemand die in het geheel niet bekend was met het terrein van onderzoek. Daarna zijn de uitwerkingen samen doorgenomen met iemand die juist wel deskundig is op dit gebied. Op deze wijze is in overleg vastgesteld of de kategorieên inderdaad passend zijn en of de indeling van een respondent (indien dat van toepassing was) bij een bepaalde kategorie korrekt gebeurde ${ }^{2}$ ).

\subsection{Onderzoekspopulatie}

Bij een oriënterende dataverzameling wordt bij het samenstellen van de steekproef gestreefd naar diversiteit en niet naar representativiteit. Daarom werden verpleegkundigen uit diverse psychiatrische centra benaderd. Per instelling werden verpleegkundigen aangezocht die werkzaam waren in de direkte patiëntenzorg bij chronische psychiatrische patiënten.

De interviews hebben plaatsgevonden in vijf psychiatrische centra. Bij de keuze voor de instellingen werd rekening gehouden met een spreiding naar kenmerken zoals ligging, grootte en levensbeschouwing. De deelnemende instellingen varieerden. Zowel protestantse als rooms-katholieke en algemene (vanouds katholieke) instellingen namen deel. Het aantal bedden per instelling varieerde van ongeveer 300 tot ruim 800. Ook het oprichtingsjaar varieerde van midden vorige eeuw tot slechts enkele decennia geleden. De instellingen lagen ruim verspreid door heel Nederland.

Het aantal respondenten per instelling varieerde van 8 tot 13, al naar gelang de grootte van de instelling.

Het betrof 36 mannen en 16 vrouwen met een gemiddelde leeftijd van resp.: 35 en 32 jaar. De jongste deelnemer was 24 jaar; de oudste 58 jaar. Van de deelnemers

2) Voor de verwerking van de casus is dank verschuldigd aan drs. A. van der Schaft, die een groot deel van de analyses ervan uitgevoerd heeft. Mevr. M. Tilly heeft, als leek op het gebied van de psychiatrische verpleging, het materiaal in eerste instantie geskoord. Dr. R. Bambang Oetomo heeft, als deskundige op het gebied van de psychiatrie, het materiaal nogmaals samen met mij doorgenomen. 
hadden er 32 een funktie als sub- of afdelingshoofd.

Nagenoeg de helft van de deelnemers had langer dan vijf jaar ervaring met het verplegen van chronische patiënten. Deze ervaring varieerde van 1 jaar tot 23 jaar. Op twee H.B.O.V.-ers na hadden alle respondenten een diploma Verpleegkunde-B. Naast de B-opleiding hadden 11 respondenten ook een A-opleiding gevolgd. De kaderopleiding werd door 18 respondenten afgerond. De helft, 26 verpleegkundigen hadden deelgenomen aan andere opleidingen, zoals bijwoorbeeld inrichtingswerk of interne bijscholingen ${ }^{3}$ ).

De steekproef voldeed aan de eis van kwalitatieve spreiding. Zowel leeftijd (en ervaring), als opleidingen en funkties waren gevarieerd vertegenwoordigd. Dit gold ook voor de vertegenwoordiging van de afdelingen. Verpleegkundigen werkzaam op diverse afdelingen, zoals verblijfsafdelingen, afdelingen voor interne resocialisatie en sociowoningen of daarop gelijkende afdelingen zoals hostels namen deel aan de interviews.

\subsection{Taken van psychiatrisch verpleegkundigen}

De eerste vraag uit de interviews luidde: "Beschrijf eens een werkdag". Dit leverde een veelheid aan informatie op over de werkzaamheden van psychiatrisch verpleegkundigen. De handelingen ten behoeve van de direkte patiëntenzorg zijn in grote lijnen als volgt samen te vatten:

* Het toezien op en, waar nodig, assisteren bij de lichamelijke verzorging van de bewoners. Dit hield bijvoorbeeld in het wekken van de mensen, helpen bij wassen en aankleden en het geven van medicijnen, het onderhouden van eigen kamers en de gemeenschappelijke ruimten. Verpleegkundigen helpen bij het 'totale voedingsgebeuren'. Dit bestaat uit het helpen met tafeldekken, eten delen (mee-eten in sommige instellingen); het helpen met boodschappen doen, koken of zelf koken voor bewoners. Nagenoeg iedereen vermeldde het gezamenlijk koffiedrinken met patiënten.

* Daarnaast werden aktiviteiten genoemd die gericht waren op aktiviteiten van de bewoners, zoals het erop toezien dat bewoners naar therapieën gingen en het ondernemen van gezamenlijke aktiviteiten. Belangrijk daarbij was vooral de begeleiding in het sociaal verkeer tussen de bewoners onderling.

3) De gegevens over de respondenten zijn in Bijlage A vitwoeriger weergegewen, in de vorm van tabellen. 
De ordening van de werkzaamheden nadr gelijksoortige aktiviteiten leverde een aantal kategorieën op, variërend van de zorg rond de maaltijden tot de organisatie van de zorgverlening (zie Figuar 2.1.).

\section{* Maaltijden}

De taak rond de maaltijden kan variëren van het stimuleren van bewoners tot corvee taken, tot het koken voor hen, of het helpen daarbij.

\section{- Persoonlijke verzorging}

Dit varieert van het toezien op de verzorging tot het helpen met baden en douchen.

\section{* Kleding}

Toezien op de was. Dit will zeggen de was doen, of het helpen hierbij.

\section{* Huishoudelijke taken afdeling}

Dit varieert van het zelf poetsen van de w.c. tot het toezien op het onderhoud van de afdeling door bewoners.

\section{- Medicijnen}

De verpleegkundige deelt de medicijnen uit, of ziet toe op het gebruik ervan wanneer bewoners ze in eigen beheer hebben.

\section{* Begeleiding sociaal verkeer}

Hierbij gaat het om zaken als het stimuleren van bewoners tot aktiviteiten, zelf deelnemen aan die aktiviteiten, opvangen van bewoners en het scheppen wan een leefklimaat op de afdeling.

\section{* Organisatie zorgverlening}

Dit is een taak gericht op het scheppen van voorwaarden om de zorgverlening op afdelingsniveau te kunnen realiseren. $\mathrm{Er}$ is sprake van overdracht van informatie aan kollega's, maken wan werkafspraken en het opstellen van beleids- en behandelplannen.

Figut 2.1. Werkzaamheden van psychiatrisch verpleegkundigen op longstay-afdelingen

In zoverre deze aktiviteiten gericht zijn op de direkte zorgverlening is een verdeling aan te brengen van enerzijds 'geheel zelf doen door de verpleging' en anderzijds 'geheel zelf doen door de bewoner'. Tussen deze twee uitersten zijn allerlei varianten mogelijk. In feite is er sprake van een continuum in de zorgverlening (zie Figuur 2.2.). 


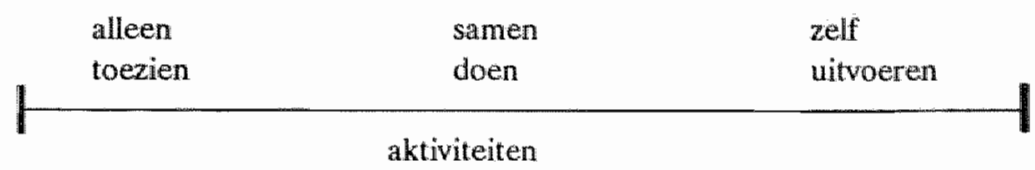

Figut 2.2. Zorgwerlening in een continuum

Een beperking van de verkregen informatie over de werkzaamheden bestaat daaruit dat men vooral de 'tastbare' aktiviteiten noemt. Om die beperking tegen te gaan is ook gevraagd over welke vaardigheden men moet beschikken om het werk te doen. Voor deze benadering werd gekozen, omdat, naar aangenomen werd, vaardigheden betrekking hebben op handelingen die verpleegkundigen verrichten tijdens hun werk. Vaardigheden worden veelal geformuleerd onder het gebruik van 'kunnen'. Bijvoorbeeld: iets kunnen uitleggen. Dit werd dan beschreven als: iets uitleggen als aktiviteit. Op deze wijze werden uit de vraag naar de vaardigheden een aantal aktiviteiten afgeleid. Deze vulden de hierboven genoemde aktiviteiten aan, en gaven daarom een kompleter beeld van de taken van psychiatrisch verpleegkundigen. Dat gaf de mogelijkheid om een driedeling aan te brengen in de werkzaamheden van de psychiatrisch verpleegkundigen. De taken werden aldus ingedeeld in team-aktiviteiten, organisatie van de zorgverlening en direkte zorgverlening (zie Figuur 2.3.).

Een vergelijking met de indeling uit Figuur 2.1. toont dat de rubriek team-aktiviteiten nieuw is. De organisatie van de zorgverlening komt in beide indelingen voor. De eerste vijf kategorieën uit Figuur 2.1. maken deel uit van de direkte zorgverlening. De driedeling uit Figuur 2.3. kan derhalve beschouwd worden als een ruimere indeling van de werkzaamheden van de psychiatrisch verpleegkundige, waarbij de eerder vermelde aktiviteiten gezien worden als een nadere invulling van de direkte zorgvertening.

Ter aanvulling van de informatie op de vragen werd een casus aan de respondenten voorgelegd. Daarbij werd onder andere gevraagd om aan te geven wat de taak van de verpleegkundige was ten aanzien van de in de casus beschreven patieñ ${ }^{4}$ ).

4) Het ging daarbij om een man van middelbare leeftijd, die ma een aantal heropmames goed funktioneerde in de instelling. Als bijzonderheid gold dat hij al jaren dezelfde kleding droeg en dat hij beslist niet overgeplaatst wilde worden naar de sociowoningen. 


\section{* Tean-aktiwitelten:}

Dit betrett zaken als het onderling samenwerken van verpleegkundigen, elkar feedback geven, rekening houden met anderen, in een team kunnen werken.

- Aktiviteiten die betrekking hebben op de organisatie zorgverlening: Methodisch kunnen werken; goed kunnen organiseren; koördineren, rapporteren.

- Aktiviteiten m.b.t. direkte zorgverlening: Het omgaan met bewoners; het bieden van struktuur, gezelligheid, sfeer kunnen scheppen, doorbreken van spanningen, winnen van vertrouwen, aangatan wan relaties, konsekwent handellen, soepel met situaties om kunnen gaan, de leiding kunnen zo nodig direktief kunnen optreden.

Figuur 2.3. Driedeling taken psychiatrisch verpleegkundigen

Eenduidig was men zeker niet. Men gaf tegengestelde opvattingen weer, zoals de patiënt zijn gang laten gaan als deze daar gelukkig mee was, of op direktieve wijze overplaatsen naar sociowoningen. Als taken van de psychiatrisch verpleegkundigen bij de begeleiding van de patiënt uit de casus werden genoemd:

- het verzamelen van informatie over de patiënt;

- het koördineren van de zorgverlening;

- stimuleren van de patiënt in zijn persoonlijke verzorging;

- stimuleren van kontakten met de familie;

- een vertrouwensrelatie opbouwen;

- aktiviteiten stimuleren of afremmen;

- direktief of non-direktief optreden.

Ook deze aktiviteiten zijn onder te brengen in de driedeling die in Figuur 2.2. weergegeven is; respektievelijk bij organisatie van de zorgverlening (punt 1 en 2) en bij direkte zorgverlening (punt $3 \mathrm{t} / \mathrm{m} 7$ ).

De taken met betrekking tot de direkte zorgverlening, zoals die vermeld werden bij de casus, zijn van geheel andere aard dan de taken die bij de beschrijving van de werkdag geïmventariseerd zijn. Zij korresponderen wel meer met de direkte zorgverlening zoals die naar aanleiding van de vaardigheden beschreven zijn. In zekere zin gaat het bij de beschrijving van de werkdag om de begeleiding bij alledaagse zaken. De uitwerking van de casus en de vaardigheden wijzen meer op de intentie van het handelen van de verpleegkundigen. Bij de beschrijving van een werkdag ging het 
meer om de middelen die gebruikt werden (alledaagse zaken) om het begeleidingsproces gestalte te geven.

Een vergelijking van de hiervoor beschreven taken met de taken die in hoofdstuk 1 vermeld zijn laat een opvallende gelijkenis met de drie aspekten van Kramer zien (zie hfdst.1.).

Het eerste aspekt heeft betrekking op het op de juiste wijze verzorgen van een patiènt die dat zelf niet voldoende kan. Dit is te vergelijken met de begeleiding bij alledaagse aktiviteiten.

Het tweede aspekt heeft betrekking op het behulpzaam zijn van de arts. Dit kwam nu niet naar voren bij de taken, doch is wellicht te wijten aan het feit dat de omschrijving van Kramer gedateerd is. Zijn boek is ruim twintig jaar geleden voor het eerst uitgegeven. De team-aktiviteiten vormen daarom mogelijk de hedendaagse variant daarvan.

Het derde aspekt, de verpleegkundig-therapeutische aspekten met betrekking tot de beïnvloeding en begeleiding spoort met de taken zoals die afgeleid zijn uit de vaardigheden en de casus.

Ook de opsomming van taken van Schuring e.a. (zie hfdst.1.) vertoont veel overeenkomstige aktiviteiten met de informatie uit de interviews. De omschrijvingen van de N.Z.R. en van Kerstens (zie hfdst.1.) zijn op een abstrakter niveau geformuleerd. De taken passen daar echter goed in.

De omschrijving van de taken van de psychiatrisch verpleegkundigen komt redelijk overeen met de taken zoals die in de literatuur beschreven zijn.

Kramer maakt daarbij feitelijk een onderverdeling van de op de direkte zorgverlening gerichte taken. Dezelfde onderverdeling wordt ook afgeleid van de informatie uit de interviews. Het gaat daarbij in wezen om wat door Van Bergen en Hollands (1978) werd omschreven als het instrumenteel technische aspekt en het agogische aspekt van het verpleegkundig handelen ${ }^{5}$ ). Het instrumenteel-technische is bedoeld als het 'tekortenoplossend verhelpend handelen'. Belangrijk is daarbij de opmerking van de auteurs dat beide aspekten onlosmakelijk met elkaar verbonden zijn. Dit komt met name tot uitdrukking in het feit dat er een continuum is van enerzijds geheel overnemen van aktiviteiten (instrumenteel) tot het aan de patiënt overlaten van de aktiviteiten en zonodig begeleiden daarbij (agogisch). Ook komt dit tot uitdrukking in het feit dat de alledaagse aktiviteiten als middel gezien kunnen worden voor het bewerkstelligen van het begeleidingsproces.

5) Instrumenteel technisch dient daarbij wel in ruime zin opgevat te worden. Het betreft niet het louter technisch bezig zijn, doch het instrumenteel handelen dat gericht is op de alledaagse zorgverlening. 
Aan de hand van de informatie uit de interviews is de taak van de psychiatrisch verpleegkundigen bij de begeleiding yan chronische patiënten als volgt te omschrijven:

Het participeren in een leefmilieu van bewoners waarbij, indien nodig, gedrag bijgestuurd wordt en/of aktiviteiten van de bewoners overgenomen worden; en het scheppen van een struktuur waarin bovengenoemde mogelijk is.

De betekenis van het vooronderzoek bestond met name uit de inventarisatie van konkrete aktiviteiten. Deze aktiviteiten bleken te dienen als middel om de doelstellingen van de taakstelling te realiseren. Dit is te omschrijven als:

Het door middel van agogische vaardigheden begeleiden van chronische psychiatrische patiènten met gebruikmaking van alledaagse aktiviteiten.

Begeleiden is daarbij de intentie van het handelen. De alledaagse aktiviteiten zijn het middel daartoe. Agogisch handelen verwijst naar de aangewende techniek om middel en intentie op elkaar af te stemmen.

De alledaagse aktiviteiten blijken een belangrijke plaats in te nemen bij de taken van psychiatrisch verpleegkundigen. Dit wordt door Cosijns (1982) gezien als zowel de sterke als de zwakke kant van de psychiatrische verpleging. De sterke kant is de mogelijkheid om via alledaagse zaken op spontane wijze de patiënt te benaderen. De zwakke kant bestaat daaruit dat het hanteren van alledaagse zaken zo vanzelfsprekend is, dat men zich daarmee als psychiatrisch verpleegkundige nauwelijks weet te profileren binnen het multidisciplinaire team als een eigen deskundigheid.

\subsection{Positie van de psychiatrisch verpleegkundige binnen de organisatie van de psychiatrische centra}

Aan de respondenten werd gevraagd wat hun positie als psychiatrisch verpleegkundige binnen de instelling was. Hoewel deze vraag bedoeld was om informatie over de positie ten opzichte van de andere disciplines te verkrijgen, ging men daar veelal anders op in. In de antwoorden lag enerzijds de nadruk op de zelfstandigheid op afdelingsniveau, anderzijds op de matige betrokkenheid op beleidsniveau. Ook gaf men aan de uitvoerder te zijn van zaken die op beleidsniveau beslist werden. Op afdelingsniveau was sprake van overleg op basis van gelijkwaardigheid met de overige disciplines. Gesteld werd dat die disciplines als konsulent geraadpleegd werden, waarbij het ook kon gaan om ondersteuning van de verpleging zelf. Ook werd gewag 
gemaakt van een ondergeschikte positie, waarbij de verpleegkundige niet serieus genomen werd, terwijl naar hun zeggen de verpleegkundige de belangrijkste figuur uit de organisatie was. Verpleegkundigen waren huns inziens namelijk het meest betrokken bij de patiënt en namen ten aanzien van de patiënt een centrale plaats, in de organisatie in, zoals men zei.

De positie werd aldus verschillend ervaren en varieerde wan ondergeschikt en uitvoerend tot autonoom en centraal. Het spreekt voor zich dat de funktie (al dan niet leidinggevend) van invloed was op de ervaren positie. Dit gold evenwel niet voor de 'centrale positie'. Die werd zowel door leidinggevenden als niet-leidinggevenden genoemd. In zekere zin is dat ook begrijpelijk, aangezien de 'centrale positie' niet verwijst naar een plaats in de hiërarchie van de organisatie, doch naar de plaats tussen de andere disciplines. Aangezien de vraag daar op betrekking bedoelde te hebben, werd ook gevraagd om de taakafbakening met de andere disciplines aan te geven. Nagenoeg de helft van de 52 respondenten gaf aan dat verpleegkundigen nauwer kontakt met de patiënt hebben, dan andere disciplines. De andere disciplines hebben daarentegen, volgens de respondenten, gerichtere kontakten met de patiënt. Ook werd genoemd dat andere disciplines het begeleidingsproces meer op afstand bewaken.

De taken van de overige disciplines vertoonden overlap met die van de verpleging. Hierbij kon onderscheid aangebracht worden naar de drie meest genoemde disciplines: psychiater, psycholoog en maatschappelijk werker. Bij deze drie disciplines werd zowel gesproken over overlap, als over duidelijke afbakening. Ten aanzien van de psychiater bleek de taakafbakening het duidelijkst.

Ook naar aanleiding van de casus werd gevraagd om naast de taken van de verpleegkundige de taken van de andere disciplines aan te geven. In de antwoorden werd minder overlap tussen de verpleging en de andere disciplines genoemd dan bij de open vragen. Van alle disciplines werden specifieke taken aangegeven. Vermeld werden vooral maatschappelijk werker, psychiater en psycholoog.

Van maatschappelijk werkers werd het valakst gezegd dat die als taak hadden het uitzoeken van de sociale achtergronden buiten de instelling. De psycholoog zag men het meeste voor diagnostiek en behandeling. De psychiater noemde men in verband met individuele therapie en medikatie, alsmede diagnostiek. Van de aktiviteitenbegeleiders werd gezegd dat die er waren om te zorgen voor een aktiviteitenprogramma. In het algemeen zag men de andere disciplines als aanvulling van de verpleegkundige visie in het multidisciplinaire team.

Het verschil in antwoorden op de open vragen en op de vragen bij de casus is mogelijk gelijk aan het verschil tussen theorie en praktijk. Men is bekend met de specifieke aandachtsgebieden van diverse disciplines, en noemt die bij een 'papieren patiënt'. In 
de feitelijke praktijk blijken rollen en funkties te verschillen van de meningen daarover.

De taakafbakening, zoals die ervaren werd, varieerde van afgebakend tot onduidelijk en niet-afgebakend. De meerderheid van de respondenten (31 van de 52) vond de taken van de psychiatrisch verpleegkundige niet afgebakend. Op zich ligt dat ook voor de hand, gezien het gegeven dat de andere disciplines in feite taken uitvoeren die voorheen door verpleegkundigen gedaan werden. Daarnaast is er sprake van een algehele branchevervaging waarbij de grenzen tussen het takenpakket van de verschillende disciplines vervagen (Schuring e.a, 1984, deel II). De onduidelijkheid in de talakafbakening is aldus niet specifiek voor de verpleging en de overige disciplines. Het is een algemeen kenmerk van het hedendaagse psychiatrisch centrum als gevolg van de horizontale werkspecialisatie (Van Ommen, 1988).

\subsection{Positie van de psychiatrisch verpleegkundige binnen de verpleegkundige beroepsgroep}

Naar aanleiding van de vraag of een verpleegkundige opleiding voorwaarde is om op een longstay-afdeling te werken, werd door de helft van de respondenten vermeld, dat men dat niet echt noodzakelijk achtte. Op de vraag waar men dan het vak zou leren, gaf men als antwoord dat dit of in de praktijk geleerd werd, of dat men het 'gewoon moest hebben'. Dit laatste refereerde dan aan persoonlijke eigenschappen, al dan niet meegekregen 'van huis uit'. De andere helft vond een verpleegkundige opleiding wel aangewezen, namelijk vooral voor de kennis van ziektebeelden, de psychopathologie, voedingsleer en andere theoretische achtergronden.

Leidinggevenden hadden vaker een uitgesproken mening over de noodzaak tot het hebben van een opleiding dan niet-leidinggevenden. Leidinggevenden beantwoordden de vraag daaromtrent met 'neen' of met 'ja'. Niet-leidinggevenden hielden het vaker op een middenpositie 'ja/neen'.

In het algemeen blijkt dat de respondenten een weinig eenduidige mening hebben over hun werk als onderdeel van het verpleegkundige beroep. Ongeveer de helft van de respondenten vond dat hun werk eigenlijk geen verplegen was. Hierbij dient opgemerkt te worden dat men verplegen zag als datgene wat door verpleegkundigen in algemene ziekenhuizen gedaan werd. Nagenoeg unaniem waren de respondenten van mening dat het werken in de psychiatrie dermate verschilde van het werken in een algemeen ziekenhuis, dat het daarmee nauwelijks te vergelijken was. Overigens werd ook het werk in de acute psychiatrie als duidelijk anders gezien, dan het werk in de longstay. 


\subsection{Chroniciteit}

Gevraagd werd om de chronische psychiatrische patiënt te beschrijven aan de hand van de vraag: "Wat zijn dat voor mensen?". Een op die wijze geformuleerde vraag leverde problemen op, omdat de problematiek van de chronische psychiatrische patiënt te verscheiden was. Rekening houdend met bovenstaande kanttekeningen heeft men toch het een en ander genoemd over de patiënten waarmee men werkte. De antwoorden werden gebundeld tot een aantal rubrieken. Hierbij is gezocht naar gelijksoortige opmerkingen. Op deze wijze ontstonden 7 kategorieën, die overigens elkaar niet uitsluiten, noch van gelijke orde zijn.

De antwoorden variëren van abnormaal gedrag tot woonproblematiek (zie Figuur 2.4).

De meningen van psychiatrisch verpleegkundigen over chronische patiënten bleken niet wezenlijk te verschillen van de omschrijvingen die in de literatuur aangetroffen werden. Zo vatte Haveman (1987) de antwoorden van vier geneesheer direkteuren van psychiatrische centra op de vraag om chronische patiënten te definiëren als volgt samen:

- $\quad$ iemand die met een defect was genezen;

- $\quad$ personen op wie alle mogelijkheden van rehabilitatie zijn vastgelopen, maar zekerheid hierover bestaat nooit;

- chronische patiënten zijn aanwijzingen van het onvermogen van behandeling; en

- patiënten die lang en frequent zijn opgenomen.

(Haveman, 1987; blz. 11)

Ook de in hoofdstuk 1 beschreven 'thesen' over chroniciteit zijn in de antwoorden vertegenwoordigd. De hospitalisatiethese werd zelfs bij naam genoemd. De ziektethese werd eveneens aangetroffen. De nadruk lag op wat Wing en Morris (1981) sociale handicaps noemen, namelijk abnormaal gedrag, afhankelijkheid, onvermogen tot kontakten onderhouden en de daarmee samenhangende woonproblematiek.

\subsection{Algemene bevindingen}

Naast de interviews werden ter oriëntatie ook gesprekken gevoerd met funktionarissen uit andere instellingen, met funktionarissen bij de verpleegkundige hoofdinspektie, met onderzoekers uit andere instituten en met funktionarissen van de Nationale Ziekenhuisraad. In deze gesprekken werd regelmatig in verschillende versie aangegeven: "Werken in de longstay moet je niet te lang doen, anders ga je er zelf aan onderuit, of je raakt net zo gehospitaliseerd als de patiënten. Je moet kunnen werken in een situatie waarin je geen eindresultaten kunt verwachten." 


\section{* Abnomman gedrag (24)}

Het zijn mensen die zich anders dan normaal gedragen, bijvoorbeeld in de worm van het wragen van veel aandacht, "lastig zijn', of terughoudendheid of uitingen van onmachtsgevoelens en argwaan, alsmede faalangst en dwangmatige gedragingen.

\section{Ahankelijkheid (24)}

Het betreft hier uitspraken over de behoefte dan well noodzaak aan struktuur en begeleiding ook al is een zekere mate van zelfredzaamheid nog aanwezig.

\section{* Hospitalisatie (19)}

Het begrip "gehospitaliseerd" werd in meerdere varianten gebruikt. Er werd gesproken over hospitalisatie-effekten en hospitalisatie-syndroom. Ook werd aangegeven dat het feit dat de patiënten chronisch zijn een gevolg was wan het onvermogen van de psychiatrie uit de tijd waarin ze opgenomen zijn.

\section{* Onvermogen in kontakten (21)}

Het onvermogen tot het leggen en onderhouden van sociale kontakten werd op diverse wijzen benadrukt. Het betreft zowel het ontbreken aan behoefte aan kontakt met anderen als het onvermogen om met anderen in kontakt te treden.

\section{* Diagnostisch (21)}

Naast het gebruiken van psychiatrische ziektebeelden worden ook andere begrippen gebruikt die aan het medisch (psychiatrisch) denken refereren, zoals bijvoorbeeld: toestandsbeeld, onbehandelbaar en ziekte.

\section{* Intelligentie (12)}

Diverse malen werd genoemd dat chroniciteit verband zou houden met een geringe intelligentile.

\section{* Woonproblematiek (11)}

Het wonen werd centraal gesteld, bijvoorbeeld vanwege de onmogelijkheid om mensen te behandelen. Ook hier was een relatie met de onzelfstandigheid aangegeven.

Figutu 2.4. Kategorieèn chroniciteit ${ }^{6}$ )

6) Het getal tussen haakjes geeft aan hoe vaak een uitspraak genoemd werd welke bij de betreffende rubriek hoort. Het totale aantal was groter dan het aantal respondenten, ondat men verschillende dingen noemde. 
Deze reakties tonen veel overeenkomst met het verschijnsel burnout. Aangezien het vooronderzoek onder andere bedoeld was om zicht te krijgen op faktoren die mogelijk van invloed zijn op de taken van psychiatrisch verpleegkundigen, leek een madere bestudering van burnout gewenst.

\section{Konklusie}

De taken van psychiatrisch verpleegkundigen op longstay-afdelingen bestaan volgens de geinterviewde psychiatrisch verpleegkundigen uit team-aktiviteiten, organisatie van de zorgverlening en direkte patiëntenzorg. De direkte patiëntenzorg is onder te verdelen in de alledaagse aktiviteiten en de begeleiding in agogische zin.

De taak werd omschreven als: het participeren in het leefmilieu van de bewoner waarbij, indien nodig hun gedrag bijgestuurd wordt en/of aktiviteiten overgenomen worden en het scheppen van een struktuur waarin dit mogelijk was. Alledaagse zaken, zoals persoonlijke verzorging en de zorg voor de direkte omgeving vormen daarvan belangrijke aandachtsvelden.

Voor wat betreft de taken die gericht zijn op de direkte patiëntenzorg werd een continuum aangegeven variërend van alleen toezien tot geheel overnemen van aktiviteiten. Dit betekent dat taken kunnen variëren in de aard van de aktiviteiten en in de mate waarin men aktiviteiten van patiënten wil overnemen.

De identifikatie met de beroepsgroep was ambivalent te noemen. Psychiatrisch verplegen werd slechts door de helft van de 52 respondenten als verplegen beschouwd. Ook de positie in de instelling ten opzichte van de andere disciplines werd verschillend ervaren. Van belang voor verder onderzoek leek vooral de identifikatie met verplegen. Immers formeel zijn psychiatrisch verpleegkundigen per definitie verpleegkundige.

De visie op de chronische patiënt was niet éenduidig. Patiënten werclen zowel in termen van ziekte als hospitalisatie gezien. De gevarieerde visies kwamen wel overeen met de diverse aspekten die in de literatuur over chronische patiënten aangetroffen worden.

Zijdelings viel de aandacht op het belang van het zogenaamde burnout-fenomeen voor het verder onderzoek. In het volgende hoofdstuk zal daar nader op ingegaan worden. 



\section{HET ONDERZOEKSMODEL}

\section{Inleiding}

In dit hoofdstuk zal, uitgaande van de probleemstelling, nagegaan worden welke verschijnselen in het hoofdonderzoek bestudeerd worden. Tevens wordt aangegeven hoe die verschijnselen verwacht worden samen te hangen. De verwachte verbanden zullen in een onderzoeksmodel, dat dient als leidraad voor de analyses van het hoofdonderzoek, weergegeven worden.

\subsection{Het algemene onderzoeksmodel}

De probleemstelling van dit onderzoek, zoals weergegeven in de inleiding, luidt als volgt:

A. Welke opvattingen hebben psychiatrisch verpleegkundigen omtrent hun taken ten behoeve van psychiatrische patiënten?

B. Hoe zijn eventuele verschillen in taakopvattingen van psychiatrisch verpleegkundigen te verklaren?

Etzioni (1969) beschrijft reeds in 1969 dat met name verpleegkundigen in psychiatrische instellingen geneigd zijn om hun gedrag te richten naar datgene wat de samenleving buiten de instelling van hen verwacht. Zo wordt de taakstelling beïnvloed door datgene wat maatschappelijk als positief gehonoreerd wordt (Mok, 1973). Recente publikaties attenderen eveneens op deze invloed van maatschappelijke opvattingen op het funktioneren van verpleegkundigen (N.R.V., 1983).

In hoofdstuk 1 werd er op gewezen dat veranderde opvattingen over de zorg van psychiatrische patiënten geleid hebben tot wijzigingen in de taken van psychiatrisch verpleegkundigen. De achterliggende gedachte hierbij was de zogenaamde antihospitalisatiethese. Deze veronderstelt dat de visie op de problematiek van de chronische patiënt verband houdt met de taakopvattingen van psychiatrische verpleegkundigen.

In samenhang met de vernieuwde visie op de zorg voor chronische patiënten is de rol van de verpleegkundige gewijzigd.

De identiteit van het beroep van psychiatrisch verpleegkundige werd daardoor aangetast. Het aksent in de behandeling van psychiatrische patiënten verschoof namelijk van verzorging naar begeleiding. Met name de (agogisch-) begeleidende taken leidden tot vragen omtrent de beroepsidentiteit van psychiatrisch verpleegkundigen (zie hoofdstuk 1). 
Aangezien een wijziging in de taken van psychiatrisch verpleegkundigen leidde tot diskussies omtrent de beroepsidentiteit wordt verondersteld dat er samenhang bestaat tussen de beroepsidentifikatie en de taakopvattingen van psychiatrisch verpleegkundigen.

Tijdens de bezoeken aan de psychiatrische centra werd gewezen op problemen die verband hielden met het werken als psychiatrisch verpleegkundige. De aandacht werd vooral gevestigd op een verschijnsel dat men aanduidde als 'gehospitaliseerde verpleegkundigen'. Bedoeld werd daarmee dat verpleegkundigen die geruime tijd hun vak uitoefenen min of meer immuun raken voor de problemen van patiënten en alleen nog maar routinematig de hoogst noodzakelijke zorg verrichten. Gelijksoortige symptomen worden in de literatuur aangetroffen als het burnout-syndroom (Keirse, 1987a). In het onderzoek zal daarom nagegaan worden of burnout samenhang vertoont met taakopvattingen van psychiatrisch verpleegkundigen.

Naast visies van psychiatrisch verpleegkundigen op de problematiek van de clironische patiënt, de beroepsidentifikatie en de mate waarin er sprake is van burnout, is een aantal meer objektieve kenmerken te benoemen die eveneens van invloed kunnen zijn op de taakopvattingen. Daarbij kan gedacht worden aan kenmerken zoals: leeftijd, ervaring, geslacht, funktie en opleidingen.

Hoewel de veranderingen in de psychiatrische centra in grote lijnen eenzelfde patroon weergeven, namelijk het ontstaan wan sektoren en een sociaal wetenschappelijk benadering (naast een medische) van de problematiek van de psychiatrische patiënten, is denkbaar dat de mate waarin die veranderingen plaats vinden verschilt tussen de instellingen. Tijdens bezoeken aan psychiatrische centra ontstond namelijk de indruk dat er verschillen bestaan tussen de instellingen onderling die wellicht het beste te omschrijven zijn als verschillen in instellingskultuur. Het wordt daardoor niet uitgesloten geacht dat takopvattingen van psychiatrisch verpleegkundigen verschillen tussen psychiatrische centra.

Uitgaande van bovenstaande overwegingen is een onderzoeksmodel samengesteld (zie Figuur 3.1.). De afhankelijke variabele in het model is de takopvatting van psychiatrisch verpleegkundigen. De onafhankelijke variabelen bestaan uit twee groepen. Een groep omvat min of meer objektieve kenmerken, waarvan het in sociaal-wetenschappelijk onderzoek gebruikelijk is dat ze als onafhankelijk variabele beschouwd worden. Het gaat daarbij om de persoonskenmerken en het werk: de instelling en de sektor waar men werkzaam is. De tweede groep omvat variabelen die niet per definitie als onafhankelijke variabelen gelden, doch die in dit onderzoek op deze wijze geïnterpreteerd zullen worden. Het betreft visies van verpleegkundigen en burnout. 


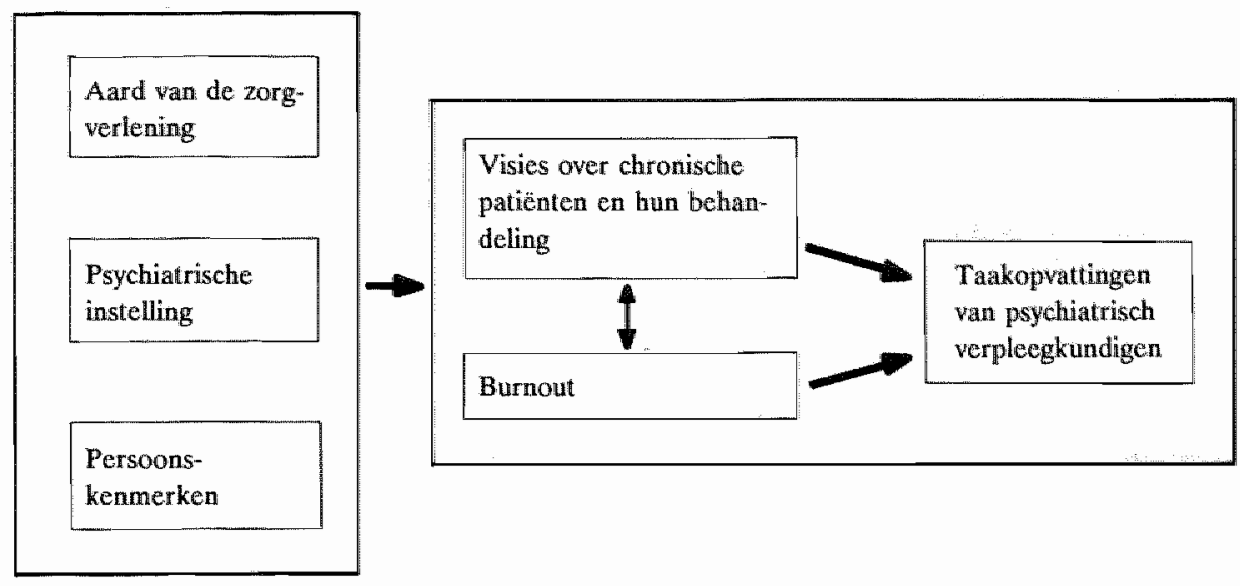

Figutur 3.1. Nominale onderzoeksmodel

\subsection{Taakopvattingen}

Bij dit onderzoek gaat de aandacht wit naar wat psychiatrisch verpleegkundigen vinden dat zij doen; dus de eigen perceptie van de taken. Gekozen is dus voor een. onderzoek naar meningen van psychiatrisch verpleegkundigen over hun werk. Het aksent ligt daarbij op de aktiviteiten die verpleegkundigen zeggen te verrichten. Het gaat niet om de formele taakkenmerken, zoals in onderzoek naar taakkenmerken. veelal gebruikelijk is (Algera, 1984). Bij een dergelijke benadering gaat het om zaken als de autonomie of de gevarieerdheid van het werk (zie o.a. Hackman \& Oldham, 1975). Ook gaat het in dit onderzoek niet om het bestuderen van gedrag of de kapaciteiten van verpleegkundigen. Hoewel een dergelijke benadering zeker relevant zou zijn bij onderzoek naar de taken van psychiatrisch verpleegkundigen, ligt het meer voor de hand om eerst de nadruk te leggen op onderzoek naar de inhoud van de taken. Informatie daarover is wel beschikbaar, doch veelal gebaseerd op eigen meningen van auteurs of omschreven als wat die taken zouden moeten zijn (zie hfdst.1). Het gaat in dit onderzoek daarom om: de aktiviteiten die door psychiatrisch verpleegkundigen verricht worden. In Hoofdstuk 2 werd een onderverdeling. gemaakt in team-aktiviteiten, organisatie van de zorgverlening en de direkte zorgverlening. De direkte zorgverlening werd onderverdeeld in twee aspekten, namelijk de zorg voor de alledaagse aktiviteiten en de meer agogisch begeleidende aktiviteiten. Het onderzoek is gericht op patiëntgebonden aktiviteiten. Aktiviteiten met betrekking tot begeleiding van leerlingen, team-aktiviteiten en organisatie blijven daarom buiten beschouwing. Dat geldt ook voor datgene wat zich op een meer algemeen niveau afspeelt, zoals: het opbouwen van relaties; het winnen van vertrouwen ${ }_{s}$ of het 
scheppen van een bepaalde sfeer op de afdeling. De nadruk ligt derhalve niet op de interitice van het handelen doch op zaken zoals:

- $\quad$ zorg voor de maalijden
- $\quad$ persoonlijke verzorging
- $\quad$ medicijoudetijke taken op de afdeling
- $\quad$ begeleiding bij social verkeer

Het onderzoek is gericht op opvattingen. Het gaat namelijk om uitspraken van psychiatrisch verpleegkundigen over hun werk. In het algemeen zijn uitspraken onder te verdelen in drie typen (Philipsen, 1988). Zo kunnen psychiatrisch verpleegkundigen aangeven dat zij patiënten vaak behulpzaam zijn bij het oplossen van relationele problemen (objektieve / kognitieve uitspraak). Een ander type uitspraak is bijwoorbeeld: "lk vind dat ik patiënten vaker bij relationele problemen behoor te begeleiden" (evaluatieve / normatieve uitspraak). Naast opvattingen over wat men doet en wat men vindt dat men behoort te doen, is ook een opvatting over de beleving daarvan te onderscheiden: "Het begeleiden van patiënten bij relationele problemen vindt ik leuk werk",of "Dit soort werk vind ik uitputtend" (subjektieve / affektieve uitspraak).

In het eerste geval gaat het om het oordeel van bijwoorbeeld de mate waarin iets voorkomt. Het evaluatieve daarentegen geeft aan hoe men dit beoordeelt, bijvoorbeeld of men het meer of minder behoort te doen. In andere bewoordingen zou gesproken kunnen worden over de feitelijkheid en de wenselijkheid. Dat wil zeggen: hoe vaak verricht men een bepaalde aktiviteit, en hoe vaak zou men dat naar eigen mening behoren te doen. Deze twee benaderingen, de feitelijkheid en de wenselijkheid, vormen de afhankelijke variabele van het onderzoek. De affektieve benadering komt in het onderzoek met name tot uitdrukking als een onafhankelijke variabele, namelijk burnout.

De affektieve uitspraken verwijzen naar de beleving van het werk. $\mathrm{Zij}$ geven het raakvlak met de in het onderzoek opgenomen meting daarvan als het burnout-syndroom aan.

Aangezien bij het onderzoek gebruik gemaakt wordt van een enquête, is de opgave van de respondenten per definitie een gepercipieerde feitelijkheid. Men geeft de ervaren feitelijkheid weer. Strikt genomen is het onderzoek daarmee beperkt tot takopvattingen Dit is evenwel een konsekwentie van de gekozen onderzoeksmethode. De ervaren feitelijkheid zal derhalve als feitelijkheid beschouwd worden. Alleen daar waar dit tot misverstanden zou kunnen leiden, wordt aangegeven om welk type uitspraak het gaat. Zonder nadere aanduiding betreft het de (ervaren) feitelijkheid, dus de mate waarin men aangeeft de aktiviteiten te verrichten. 


\subsection{Opvattingen over chroniciteit en beroepsidentifikatie}

\section{Visie op Chroniciteit}

In hoofdstuk 1 werd vermeld dat veranderingen in de taken van psychiatrisch verpleegkundigen samenhangen met de ontwikkelingen in de geestelijke gezondheidszorg. Van belang bij die ontwikkeling is vooral de opvatting over chroniciteit, die uitmondde in de anti-hospitalisatiegedachte. Dit laatste wil zeggen dat men in de zorgverlening aan chronische psychiatrische patiënten de zelfstandigheid van deze mensen zoveel mogelijk dient te bevorderen. Het doel daarvan is het tegengaan van het afhankelijk worden van psychiatrische patiënten van de hulpverlening c.q. de hulpverleners. Verpleegkundigen worden in hun opleidingen gewezen op hun taak bij het tegengaan van hospitalisatie-effekten. Dat wil zeggen dat van verpleegkundigen wordt verwacht dat zij zo veel mogelijk aan patiënten zelf overlaten. Immers het overnemen van aktiviteiten wordt gezien als een van de redenen waarom psychiatrische patiënten afhankelijk (dreigen te) worden (Barton 1966; Offerhaus, 1983). Hun grondhouding dient daarom gebaseerd te zijn op het respekteren van de zelfstandigheid van de patiënt. De visie op de oorzaken van 'chroniciteit' hebben hun weerklank gevonden in de taken van psychiatrisch verpleegkundigen.

De veranderde visie op chroniciteit leidde tot wijzigingen in de taken van psychiatrisch verpleegkundigen. Uit interviews met psychiatrisch verpleegkundigen (zie hoofdstuk 2) bleek dat de beschrijving die zij gaven van chronische patiënten overeenkomt met de in de literatuur beschreven chroniciteitsopvattingen. Vooral het onderscheid in ziekte- en hospitalisatiethese is daarbij van belang. De ziektebenadering past namelijk in de traditionele rol van de psychiatrische verpleegkundige: zorgen vóór de patiënt. De hospitalisatie-benadering verlangt een begeleidende rol van de verpleegkundige: stimuleren en aktiveren van patiënten.

Verwacht wordt dat de visie van psychiatrisch verpleegkundigen op chroniciteit samenhangt met hun taakopvattingen.

\section{Beroepsidentifikatie}

Zoals hiervoor reeds vermeld werd past het zorgen vór de patiënt in het traditionele beeld van verplegen. Het agogisch begeleidende handelen past meer bij een therapeutische beroepsrol. Het gaat dan om begeleiding in plaats van verpleging. De ontwikkeling van de psychiatrische centra is analoog hieraan: van zorggericht naar begeleidingsgericht. In hoofdstuk 1 werd gewezen op de parallel tussen de ontwikkeling van de psychiatrische centra en de taken van verpleegkundigen die er werken. Dit geeft aan dat daar waar psychiatrisch verpleegkundigen hun rol meer als een therapeutische beroepsrol zien, er mogelijk ook sprake is van een meer op begeleidingsgerichte invulling van hun taken. De therapeutenrol past namelijk bij het 
agogisch begeleidend aktief zijn. De rol van verpleegkundige past meer bij het zorgen voor alledaagse aktiviteiten. In die zin wordt verwacht dat verschillen in beroepsidentifikatie samenhangen met verschillen in taakopvattingen.

\subsection{Burnout}

Burnout is een verschijnsel dat vooral in verband gebracht wordt met de dienstverlenende beroepen, zoals in het onderwijs, maatschappelijk werk en de gezondheidszorg. Beoefenaars van die beroepen vormen een zekere risiko-groep. Doordat zij 'met mensen werken' lopen zij het gevaar emotioneel uitgeput of opgebrand te raken. In de literatuur worden verschillende definities en operationaliseringen van burnout naast elkaar gebruikt. Toch is er ten aanzien van drie aspekten sprake van consensus:

- burnout vindt plaats op individueel niveau;

- burnout is: "an internal psychological experience involving feelings, attitudes, motives, and expectations"

- burnout is een negatieve ervaring voor de persoon: "in that it concerns problems, distress, discomfort, disfunction, and/or negative consequences" (Maslach, 1982).

Maslach \& Jackson hebben het begrip verder uitgewerkt met de nadruk op de psychische kant van het verschijnsel. Zij stellen:

Bumout is a syndrome of emotional exhaustion and cynicism that occurs frequently among individuals who do 'people-work' of some kind.

(Maslach \& Jackson, 1981; blz. 228).

Alvorens in te gaan op de gevolgen van burnout zal aandacht besteed worden aan de oorzaken ervan. Maslach (1978) geeft aan dat het optreden van burnout gezien moet worden als een onvermogen om op een adekwate wijze om te gaan met chronische emotionele stress van het werk. Dit onvermogen wordt niet alleen de persoon in kwestie toegeschreven, doch kan het beste begrepen worden in termen van sociale en situationele bronnen (Maslach \& Jackson, 1982).

De arbeidssituatie geldt als een belangrijke bron van burnout. Alles wat leidt tot arbeidsstress kan leiden tot burnout, wanneer men niet adekwaat met die stress om weet te gaan. Rolkonflikten en/of een te grote case-load zijn hiervan voorbeelden. Het hebben van te hoge verwachtingen omtrent de vooruitgang bij patiënten en het zich te zeer identificeren met de problemen van die ander gelden eveneens als oorzaken van burnout. 
Hoewel burnout ontstaat als gevolg van het werken met mensen, heeft het verschijnsel ook effekt op de wijze waarop men zijn werk uitvoert. In de psychiatrische verpleging is naast de (te) grote werkdruk vooral de identifikatie met de problemen van patiënten van belang, wanneer die leidt tot een (te) grote betrokkenheid bij de patiënten ontstaat een voedingsbodem voor burnout (Maslach, 1978). Het vinden van een juist evenwicht tussen afstand en betrokkenheid is een van de moeilijke opgaven waar psychiatrisch verpleegkundigen mee gekonfronteerd worden (De Lange \& Borgesius, 1988). De ongang met psychiatrische patiënten kan, bij het niet juist hanteren van het probleem van de afstand en betrokkenheid, leiden tot burnout. De betrokkenheid slaat dan om in afstandelijkheid. Eenmaal onderhevig aan burnout, leidt dit verschijnsel tot een andere benadering van het werk. De kwaliteit van de zorgverlening kan door burnout onder het personeel aangetast worden (Cherniss, 1980). Het werk verwordt namelijk tot routine en kontakten met patiënten worden tot een minimum beperkt. Men is dan niet meer ontvankelijk voor de problemen van de patiënten en vermijdt de emotionele betrokkenheid (Keirse, 1987a).

Aan de taken van psychiatrisch verpleegkundigen in de direkte patiëntenzorg werden twee aspekten onderscheiden (zie hoofdstuk 2): de alledaagse aktiviteiten gericht op de persoonlijke zorg van de patiënt en de agogisch-begeleidende aktiviteiten. Deze laatste aktiviteiten zijn gericht op het ondersteunen van de patiënt in psycho-sociale problemen. Hoewel beide aspekten nauw met elkaar verweven zijn is het denkbaar dat bij optredende burnout juist die psycho-sociale begeleiding afneemt. Immers de dagelijkse zorg, het behulpzaam zijn bij zaken als tafels dekken, kleding wassen en dergelijke, leent zich voor een routinematige aanpak. Aandacht voor psycho-sociale problemen vereist een zekere mate van (emotionele) betrokkenheid en laat zich niet met routine-antwoorden afdoen. Daarnaast is de omgang met de patiënt een basisvoorwaarde voor psycho-sociale begeleiding. Kontakten met patiënten dienen dus niet vermeden te worden, doch juist bevorderd.

Gediplomeerde verpleegkundigen werken in een positie die het vermijden van kontakten met de patiënt mogelijk maakt. Zij kunnen de noodzakelijke zorgverlening aan leerlingen overlaten en zelf 'vluchten" in kantoorwerk en overlegtaken. Burnout hoeft daarom niet noodzakelijkerwijs tot ontslag te leiden, aangezien er in de werksituatie voldoende mogelijkheden bestaan om de betrokkenheid met de patiënt te vermijden. In die zin wordt verondersteld dat er een verband bestaat tussen burnout en de (feitelijke) taakopvattingen van psychiatrisch verpleegkundigen. In het onderzoek zal daarom burnout beschouwd worden als een verschijnsel dat de taakopvattingen beïnvloedt. 


\subsection{Aard van de zorgverlening}

In de vorige paragrafen werd reeds gebruik gemaakt van de begrippen shortstay en longstay. Deze sektoren bestaan uit een aantal afdelingen die onderling verschillen. De shortstay-afdelingen hebben gemeenschappelijk dat de patiënten er opgenomen worden voor kortdurende (tot twee jaar) behandeling. In de longstay-afdelingen verblijven patiënten die langdurig opgenomen zijn in de psychiatrische instelling: de clironische psychiatrische patiënten.

De sektoren verschillen niet alleen in het type patiënten dat er verblijft doch ook in de samenstelling van de teams die er werken en in de overlegstrukturen (Van Ommen, 1988).

Met name door het verschil in doelstelling van de sektoren (behandelen of beschermd woonmilieu bieden) wordt verwacht dat de taakopvattingen van verpleegkundigen er verschillen.

\subsection{Persoonskenmerken}

Uit de analyses van de interviews (zie hfdst.2) is gebleken dat leidinggevende een meer uitgesproken mening hebben over het al dan niet noodzakelijk zijn van het gevolgd hebben van een verpleegkundigen opleiding, dan niet-leidinggevenden. Daarnaast mag in het algemeen aangenomen worden dat taken gerelateerd zijn aan funktie. Het is dus van belang de taakopvattingen te vergelijken tussen leidinggevenden en niet-leidinggevenden.

Uit een eerder uitgevoerde analyse van de relatie tussen funktie, geslacht en leeftijd van psychiatrisch verpleegkundigen (Dassen, e.a., 1987/88) is gebleken dat er verband bestaat tussen geslacht en funktie. Eveneens bleken er verschillen in gemiddelde leeftijd tussen mannelijke en vrouwelijke psychiatrisch verpleegkundigen, werkzaam in diverse sektoren. Het kontroleren van de onderzoeksbevindingen voor geslacht is aldus gewenst.

Hoewel funktie en ervaring (en leeftijd) wellicht samenhangen, zullen niet alle verpleegkundigen met een lange ervaring een leidinggevende positie innemen. Ervaring en zal derbalve eveneens als persoonskenmerk bij het onderzoek betrokken worden.

Van andere orde is de opleiding. In hoofdstuk 1 werd reeds besproken dat de opleiding inrichtingswerk een gebruikelijke vervolgopleiding voor psychiatrisch verpleegkundigen is.

De opleiding inrichtingswerk is gericht op werkers die zich op enigerlei wijze bezig houden met kliënten binnen residentiële hulpverlenings- en/of verblijfsituaties. Speciaal wanneer het de 24-uurs verblijfsituatie betreft. Het kan dus gaan om psychiatrische instellingen, internaten, kindertehuizen, gevangenissen. Kortom overal, waar mensen in instituten verblijven. 
De aktiviteiten van inrichtingswerkers bestaan uit het doelgericht samen met (of juist niet) de kliënten vaststellen van huisregels, maken wan afspraken, plannen van aktiviteiten, het reguleren (of juist niet) van interakties tussen kliënten.

Het verschil met de B-opleiding heeft dus vooral betrekking op het gericht zijn op groepen. Bij de B-opleiding gaat het om meer individueel gericht zijn, bijwoorbeeld: letten op de stemming, het geheugen, de motoriek etc. van de patiënt.

Gezien het verschil in benadering van beide opleidingen zal in het onderzoek een vergelijking tussen verpleegkundigen met en zonder een opleiding inrichtingswerk opgenomen worden.

\subsection{Psychiatrische centra}

Aangezien de veranderingen in de psychiatrische centra, zoals bijvoorbeeld het ontstaan van de sektoren, een ingrijpend proces van organisatieverandering zijn, is denkbaar dat de ontwikkeling in de zorgverlening niet in alle instellingen parallel lopen. Van oudsher zijn de psychiatrische instellingen gesloten gemeenschappen die tamelijk geïsoleerd van de maatschappij funktioneerden. Verschillen in instellingskultuur konden daardoor lange tijd stand houden ${ }^{1}$ ).

Een belangrijk kenmerk van de psychiatrische instellingen is in dit verband het gegeven dat het overgrote deel van het personeel dat in de direkte patiëntenzorg werkzaam is, door de instellingen zelf opgeleid wordt via in-service opleidingen. Deze opleiding vormt een belangrijk instrument bij het proces van het zich eigen maken van het waardensysteem, de normen en het gedragspatroon dat vereist is in de betreffende organisatie. Dit proces, dat aangeduid wordt als socialisatie, vindt ook plaats tijdens andere (beroeps-) opleidingen. In de situatie van de B-opleiding is er echter sprake van een formele socialisatie waarbij de organisatie een belangrijke invloed uitoefent. Mintzberg (1983) spreekt in dit verband, waarbij het gaat om een organisatie die de eigen leden kan socialiseren voor eigen belangen, van indoctrinatie die vooral bepaald wordt door de kultuur van de organisatie, waarbij diegenen die zich daar niet in kunnen vinden en zich dus niet laten socialiseren niet lang deel uit zullen maken van de organisatie (Hofstede, 1986).

Deze struktuur maakt het mogelijk om een zekere 'instellingskultuur' te reproduceren via de vorming van de leerlingen.

In het onderzoek zal daarom nagegaan worden of taakopvattingen van psychiatrisch verpleegkundigen verband houden met de psychiatrische instelling waar zij werkzaam zijn.

1) Hoewel er onderscheid aan te brengen is tussen instellingsklimaat en instellingskultuur (Hofstede, 1986) zal deze nuance hier verder buiten beschouwing gelaten worden. 


\section{Samenvatting}

In dit hoofdstuk werd een onderzoeksmodel gepresenteerd, dat zal dienen als leidraad woor de analyses. In Figuar 3.2. is dit onderzoeksmodel nogmaals weergegeven, doch nu met de meer uitgewerkte begrippen die in het hoofdonderzoek opgenomen zullen worden. De nadere operationalisering van deze begrippen zal in de volgende hoofdstukken besproken worden.

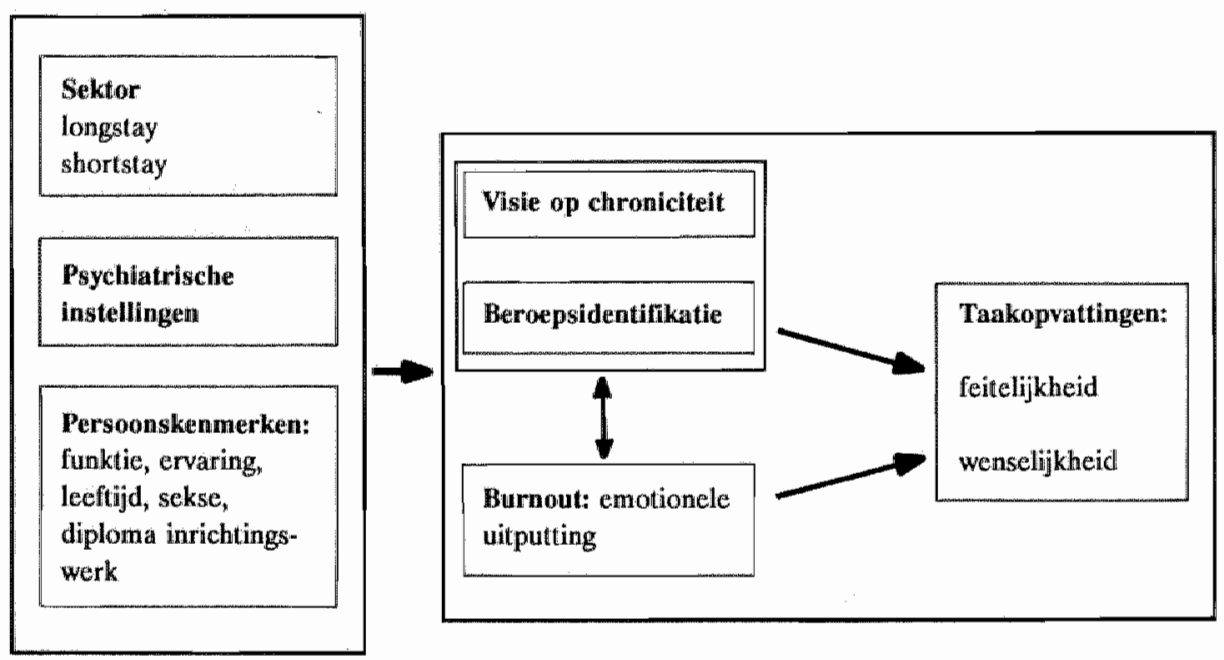

Figur 3.2. Het uitgewerkte onderzoeksmodel

De te verklaren variabele omvat de taakopvattingen van psychiatrisch verpleegkundigen, welke gericht zijn op de aktiviteiten met betrekking tot de direkte patiëntenzorg. Verondersteld wordt dat verschillen in taakopvattingen samenhangen met de visie op chroniciteit, beroepsidentifikatie en burnout. Aangezien er aanwijzingen zijn dat, zowel de laatst genoemde verschijnselen als de taakopvattingen afhankelijk kunnen zijn van de psychiatrische instelling waar verpleegkundigen werkzaam zijn, is ook de instelling als een verklarende faktor in het onderzoeksmodel opgenomen. Ditzelfde geldt voor de aard van de zorgverlening, dat wil zeggen of men al dan niet werkzaam is bij chronische psychiatrische patiënten. Daarnaast zullen de meningen van psychiatrisch verpleegkundigen gekontroleerd worden voor eventuele invloeden van persoonskenmerken, zoals o.a. leeftijd, geslacht en het al dan niet door verpleegkundigen gevolgd hebben van de opleiding inrichtingswerk. 


\section{HET HOOFDONDERZOEK}

\section{Inleiding}

De centrale probleemstelling, zoals genoemd in de inleiding, kan met behulp van de informatie uit de voorgaande hoofdstukken uitgewerkt worden tot een aantal vraagw stellingen. Deze luiden als volgt:

I. Wat zijn de taakopvattingen van psychiatrisch verpleegkundigen?

II. Welke samenhang bestaat er tussen de taakopvattingen van psychiatrisch verpleegkundigen en persoonskenmerken?

III. Welke samenhang bestaat er tussen de taakopvattingen en de visie op chroniciteit?

IV. Welke samenhang bestaat er tussen de taakopvattingen en beroepsidentifikatie?

$\mathrm{V}$. Welke samenhang bestaat er tussen de takopvattingen en burnout?

VI. Welke samenhang bestaat er tussen de takopvattingen en de aard van de zorgverlening?

VII. Welke samenhang bestaat er tussen de taakopvattingen en de instellingen?

Voor het beantwoorden van deze vraagstellingen wordt gebruik gemaakt van een schriftelijke enquête onder verpleegkundigen die werkzaam zijn in psychiatrische instellingen. In dit hoofdstuk wordt ingegaan op de selektie van de respondenten, en zal de wijze van dataverzameling toegelicht worden. Tot slot worden enkele algemene kenmerken van de respondenten besproken.

\subsection{Onderzoekspopulatie}

Het spreekt voor zich dat de onderzoekspopulatie bestaat uit psychiatrisch verpleegkundigen. Afgebakend is de doelgroep daarmee allerminst. De vraag luidt nu namelijk: wat wordt verstaan onder psychiatrisch verpleegkundigen? Zijn dit verpleegkundigen met een B-diploma? Of zijn dit alle verpleegkundigen die werkzaam zijn in psychiatrische instellingen?

Het bezitten van een B-opleiding is geen strikte voorwaarde om te werken in de psychiatrische verpleging. Zeker na de invoering van de dagopleidingen is dit niet meer een vanzelfsprekendheid. Daarnaast werken er ook verpleegkundigen met een $\mathrm{Z}$ - of A-diploma of ziekenverzorgenden in psychiatrische instellingen. Het is daarom beter om de doelgroep te beschrijven als: iedereen die als verplegende werkzaam is in 
een psychiatrisch centrum. Onder verplegenden zullen dan alleen gediplomeerden worden verstaan.

Een volgende afbakening betreft de afdelingen. Alleen verplegenden die werken op afdelingen die behoren tot de shortstay- en de longstay-psychiatrie worden benaderd. Geriatrische afdelingen blijven buiten beschouwing, aangezien op die afdelingen meer nadruk ligt op lichamelijke verzorging en dit ook van invloed is op de samenstelling van de verpleegteams. Op deze afdelingen werken namelijk relatief veel ziekenverzorgenden.

\subsection{De steekproef}

In 1986 bedroeg het aantal verpleegkundigen (inclusief verzorgend en opvoedkundig personeel) 8822 (N.Z.I., 1987). Gegevens, uitgesplitst naar sektoren zijn niet beschikbaar. Tijdens het vooronderzoek zijn deze gegevens wel verzameld. De verhouding shortstay : longstay : geriatrie was bij de vijf aan het vooronderzoek deelnemende instellingen $26: 44: 30$. Uitgaande van deze verhouding bestaat de doelgroep uit ongeveer 6200 personen, waarvan er \pm 3900 op longstay-afdelingen werken en \pm 2300 op shortstay-afdelingen. Voor 43 psychiatrische centra verdeeld over het land is dat gemiddeld \pm 145 per instelling.

Uitgaande van het aantal variabelen die het onderzoek zal bevatten wordt, met het oog op de te verrichten statistische analyses, gestreefd naar een steekproefgrootte van acht à negen honderd respondenten. Het verdelen van deze respondenten over alle instellingen stuit op praktische en onderzoekstechnische bezwaren. Het aantal per instelling zou al gauw te klein zijn om instellingen onderling te vergelijken. Het ligt daarom meer voor de hand om een aantal instellingen te selekteren. Om het streefgetal te halen zal deelname van 5 tot 6 instellingen voldoende zijn.

\subsection{Werkwijze}

Voor het verzamelen van de gegevens is gebruik gemaakt van een schriftelijke enquête. Deze techniek heeft het voordeel dat met betrekkelijk weinig middelen (tijd en mankracht) veel respondenten benaderd kunnen worden. Daarbij is deze methode zeker geschikt wanneer het gaat om het meten van de perceptie van de eigen taken (Mintzberg, 1973). Een van de bezwaren van deze techniek is het risico van een lage respons. De gehanteerde procedure was daarom gericht op het bevorderen van de respons. Om die reden werd de enquête uitgevoerd in de vorm van een boekje op A5 formaat (Zie: Nederhof, 1981). Alle respondenten ontvingen de vragenlijst in een op naam gestelde envelop, vergezeld van een op naam gesteld begeleidend schrijven, dat persoonlijk ondertekend was door de onderzoeker.

Eerst werd het onderzoek besproken tijdens een vergadering met de afdelingshoof- 
den. In een later stadium werden alle afdelingen bezocht en werd uitleg gegeven over het onderzoek aan de aanwezige verpleegkundigen. De enquêtes werden dan uitgedeeld. De werpleegkundigen die op dat moment niet aanwezig waren, ontvingen de vragenlijst via het afdelingshoofd. Na twee weken werden de vragenlijsten per afdeling weer opgehaald.

Deze werkwijze heeft als voordeel dat het persoonlijk kontakt met de onderzoeker geoptimaliseerd wordt, hetgeen mogelijk een gunstig effekt op de respons heeft. Die methode werd eerder met sukses toegepast tijdens een doctoraalstudie in een psychiatrische instelling (Van der Schaft, 1987).

\subsection{Instrumentontwikkeling}

Voor de in het onderzoek te meten begrippen bleken geen meetinstrumenten voorhanden. Dit betekende dat in hoofdzaak gebruik gemaakt diende te worden van zelf te konstrueren schalen. Alleen voor burnout kon gebruik gemaakt worden van een bestaand instrument, namelijk de Maslach Burnout Inventory Scale.

Behalve de burnoutschaal werden alle schalen samengesteld aan de hand van gegevens uit de interviews. Voor het bepalen van de afzonderlijke items werden uitspraken uit de interviews gebruikt. Per dimensie is een aantal citaten overgenomen. Zo nodig werd de formulering aangepast teneinde korrespondentie met de antwoordkategorie te verkrijgen.

Voor het testen van de schalen op interne konsistentie en op de bruikbaarheid van de formuleringen werd de lijst voorgelegd aan vier lesgroepen van de Katholieke Hogere School voor Verpleegkundigen te Nijmegen, bestaande uit verpleegkundigen werkzaam in psychiatrische centra die een kaderopleiding volgden. Het betrof 48 mannen en 21 vrouwen met een gemiddelde leeftijd van 30 jaar (s.d. 3.5). Uit de opgave van de woonplaatsen bleek dat het vooral werknemers betrof van psychiatrische instellingen uit het midden, zuiden en oosten van het land.

Het invullen van de vragenlijsten gebeurde klassikaal in aanwezigheid van de onderzoeker. Dit gaf de mogelijkheid om onduidelijkheden in de formulering direkt te bespreken. Zowel de mondelinge opmerkingen als de schriftelijke reakties bevatten waardevolle suggesties ter verbetering van de formulering van de items.

De keuze van de items voor de definitieve versie van de schalen werd bepaald met behulp van principale komponentenanalyse. Daarna werd de interne konsistentie berekend aan de hand van de Cronbachs alpha koëfficiënt.

\subsection{Deelnemende instellingen}

De instellingen werden geselekteerd op kenmerken als geografische ligging, grootte en oprichtingsjaar. Alle benaderde instellingen waren bereid om mee te werken. 
Overigens dient vermeld te worden dat het kontakt met de instellingen in drie van de zes gevallen niet uitging van de onderzoeker. Vanuit de instelling werd kontakt opgenomen met de onderzoeker met de vraag of er een samenwerking mogelijk was met de vakgroep verplegingswetenschap van de Rijksuniversiteit Limburg, bijvoorbeeld in de vorm van stageplaatsen. Bij een oriënterend gesprek daarover werd dan het onderhavige onderzoek aangeboden.

In totaal hebben zes psychiatrische instellingen aan het hoofdonderzoek deelgenomen. Eén van deze instellingen had ook deelgenomen aan het vooronderzoek, in de overige vijf gevallen ging het om nieuwe instellingen. In totaal hebben er aldus tien verschillende psychiatrische centra in het onderzoek geparticipeerd. De grootte van de zes aan het hoofdonderzoek deelnemende instellingen varieert van kleine, middelgrote tot zeer grote instellingen. Ook naar levensbeschouwelijke achtergrond zijn deze instellingen gevarieerd. Zowel algemene en (van oorsprong) katholieke en protestantse instellingen namen deel aan het onderzoek. De oudste deelnemende instelling dateert uit de vorige eeuw, de jongste is enkele decennia oud. Nagenoeg alle instellingen hebben dependances in andere plaatsen. In totaal werden uiteindelijk twintig lokaties, verspreid door heel Nederland, bezocht.

\subsection{Respons}

Alle verplegenden werkzaam op afdelingen welke behoren tot de longstay en shortstay werden in de zes deelnemende psychiatrische centra benaderd voor deelname aan het onderzoek. In totaal betrof dit 1148 personen. Er werden 898 enquêtes terug ontvangen. Dit komt neer op een respons van $78 \%$ (zie Tabel 4.1.).

Exacte gegevens over de aard van de non-respons zijn niet bekend. Volgens opgave van sommige afdelingshoofden had de non-respons vooral betrekking op ziekte, vakantie en enkele weigeringen. Uit een vergelijking van de respons per afdeling bleek dat de non-respons vooral toe te schrijven was aan de lage deelname van een beperkt aantal afdelingen. Het totaal aantal deelnemende afdelingen bedroeg ruim honderd. Bij 33 afdelingen was de respons $100 \%$. Bij 19 afdelingen was dat tussen de 80 en $100 \%$. Slechts vijftien afdelingen gaven een respons van $50 \%$ of minder.

In én instelling was de respons van de verpleegkundigen op de longstay-afdelingen beduidend lager dan elders, mamelijk $51 \%$. In de andere instellingen was dat $80 \%$ of meer. De reden voor die lage respons is niet bekend. Wel is bekend dat de respons tussen de afdelingen onderling in die instelling niet veel fluktueerde. Er is daar dus sprake van een algemene lage respons in de longstay-sektor. 
Respons naar sektor en instelling

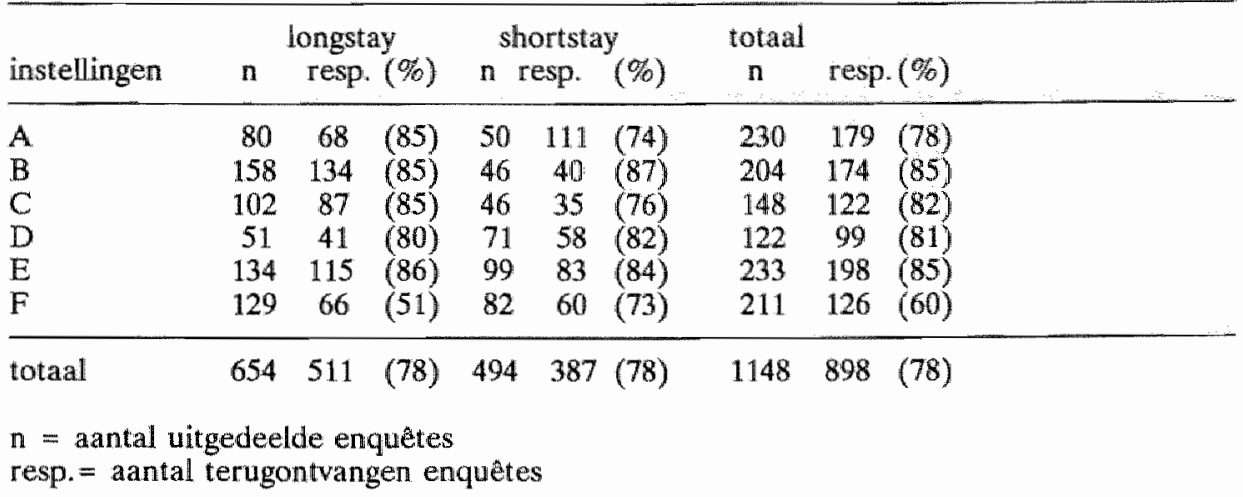

\section{Indeling in long- en shortstay}

De indeling van de steekproef in longstay en shortstay is met name nodig om de bevindingen die betrekking hebben op verpleegkundigen die bij chronische patiënten werken te kunnen vergelijken met een referentiegroep.

Een aantal respondenten maakt wel deel uit van de hierboven genoemde sektoren, maar werkt op tamelijk specifieke afdelingen. Zo blijkt dat $5 \%$ van de respondenten werkzaam is op afdelingen voor krisisinterventie. Op dit soort afdelingen gaat het om intensievere behandeling en bewaking. Het kan daarbij zowel om chronische patiënten gaan, als om mensen die niet tot die kategorie gerekend worden, doch daar omwille van tijdelijk noodzakelijke intensieve verpleging verblijven. In sommige psychiatrische instellingen spreekt men daarom niet over krisisafdelingen, maar over afdelingen voor intensive-care.

De aard van de zorgverlening op deze afdelingen verschilt dusdanig van de algemene shortstay en longstay-afdelingen, dat het niet zonder meer mogelijk is de krisisafdelingen bij dit onderzoek te betrekken. Ditzelfde geldt ook voor de sociowoningen. Van de deelnemers aan het onderzoek werkt $10 \%$ op deze afdelingen. Sociowoningen zijn eigenlijk geen afdelingen, maar woningen buiten het terrein van de instelling waar chronische psychiatrische patiënten in kleine groepen samenwonen. In vergelijking met verblijfsafdelingen zijn bewoners van sociowoningen zelfstandiger. Dit houdt in dat zij meer werkzaamheden (bijv. van huishoudelijke aard) zelf verrichten (Peeters, 1988). Een bijkomende faktor is dat het werk op de sociowoningen niet alleen inhoudelijk, doch ook organisatorisch verschilt. De taak van de psychiatrisch verpleegkundigen krijgt daardoor op een geheel andere wijze vorm (Bleeker, 1987). Het betrekken wan de sociowoningen en de krisisafdelingen bij dit onderzoek betekent dat niet die aandacht besteed kan worden aan deze vorm van zorgverlening, die daarvoor 
nodig is. Het verdient daarom de voorkeur om afzonderlijk aandacht aan deze afdelingen te besteden.

Naast de genoemde twee afdelingstypen zijn er ook een aantal verpleegkundigen werkzaam op afdelingen voor socio- en psychotherapie, afdelingen voor dagbehandeling en afdelingen met het aksent op lichamelijke zorgverlening. Ook de respondenten van die afdelingen worden niet gerekend tot de steekproef, zoals deze bedoeld is voor dit onderzoek.

Resumerend komt bovenstaande erop neer dat, van de 1148 uitgedeelde enquêtes er 898 terugontvangen zijn, doch dat van die 898 er 697 gebruikt zullen worden voor de analyses zoals deze nodig zijn voor het beantwoorden van de probleemstelling van het onderhavig onderzoek.

De krisisafdelingen, de sociowoningen en een aantal andere specifieke afdelingstypen worden buiten beschouwing gelaten, teneinde de te vergelijken groepen zo homogeen mogelijk samen te stellen.

\subsection{Achtergrondkenmerken van de respondenten}

De demografische gegevens van de respondenten worden behandeld in zoverre deze relevant geacht worden voor de analyses. Het betreft geslacht, leeftijd, funktie, ervaring, en opleidingen.

\section{Geslacht}

De steekproefverdeling naar mannen en vrouwen komt nagenoeg overeen met landelijke cijfers. Volgens opgave van het C.B.S. (1985) bedroeg op 31-12-1984 het aantal mannen in de psychiatrische verpleging $47 \%$. Tijdens het vooronderzoek, dat plaats vond in 1986, werd in de gegevens, verzameld van vijf instellingen, $53 \%$ mannen aangetroffen.

Het nagenoeg gelijke aandeel van mannen en vrouwen geldt niet voor alle deelnemende instellingen. In twee instellingen werkt $60 \%$ vrouwen; in eén instelling is dit $40 \%$. In de andere drie is dit nagenoeg $50 \%$. Als er in een instelling een oververtegenwoordiging van vrouwen is, komt dit merendeels voor rekening van de longstaysektor. Overigens werken in alle zes de instellingen relatief meer mannen in de shortstay, dan in de longstay-sektor. 


\section{Leefiijd}

De gemiddelde leeftijd van de respondenten is 33 jaar. Voor mannen is dat 34 en voor vrouwen 31 jaar. Dit verschil is statistisch signifikant $(t=6,3 \quad p<0.001 \mathrm{df}=688$ ) en komt overeen met eerder beschreven leeftijdswerschillen tussen mannelijke en vrouwelijke psychiatrisch verpleegkundigen (Dassen, e.a., 1987/88).

In het algemeen geldt dat vrouwen vanaf 25 jaar het arbeidsproces beginnen te verlaten, terwijl mannen dan nog in toenemende mate eraan deel gaan nemen (C.B.S., 1987). Dit patroon geldt ook voor de psychiatrische verpleging. Er is namelijk een oververtegenwoordiging van mannen in de middelste leeftijdsgroep (zie Tabel 4.2.). Dit geldt voor alle zes de deelnemende instellingen.

Tabel 4.2. Percentage respondenten naar geslacht en leeftijdsgroep (1988)

\begin{tabular}{lcccc}
\hline & $20-30$ & $30-40$ & $40+$ & total \\
\hline mannen & 25 & $\mathbf{5 9}$ & 15 & $100 \%=343$ \\
vrouwen & $\mathbf{5 2}$ & 35 & 13 & $100 \%=347$ \\
\hline totaal & 39 & 47 & 14 & $100 \%=690$ \\
chi $^{2}=55.39 \mathrm{p}<0.01$ & & &
\end{tabular}

Verpleegkundigen die in de longstay-sektor werken zijn gemiddeld iets ouder dan hun kollega's in de shortstay. Alleen voor de vrouwen geldt, dat dit verschil in leeftijd statistisch signifikant is (zie Tabel 4.3.).

Tabel 4.3. Gemiddelde leeftijd respondenten (1988)

\begin{tabular}{lllllll}
\hline & \multicolumn{2}{l}{$\begin{array}{l}\text { mannen } \\
\text { gem. (s.d.) }\end{array}$} & $\begin{array}{l}\text { vrouwen } \\
\text { gem. (s.d.) }\end{array}$ & $\begin{array}{l}\text { totaal **) } \\
\text { gem. (s.d.) }\end{array}$ \\
\hline shortstay & 34 & $(6.1)$ & 30 & $(6.6)$ & 32 & $(6.6)$ \\
longstay & 35 & $(7.3)$ & 32 & $(7.1)$ & 33 & $(7.4)$ \\
\hline totaal & 34 & $(6.7)$ & 31 & $(6.9)$ & 33 & $(7.0)$ \\
$*$ *) sign: $\mathrm{t}=2.37$ & $\mathrm{p}<0.05$ & $* *$ &
\end{tabular}


Tussen de instellingen onderling zijn er verschillen in de gemiddelde leeftijd wan de aldaar werkende verpleegkundigen. De gemiddelde leeftijd van verpleegkundigen in de shortstay-sektor verschilt signifikant tussen de instellingen ( $F=2.45$ $p<0.05$ ). Voor de longstay-sektor zijn er geen werschillen in gemiddelde leeftijd tussem de instellingen onderling.

\section{Funktie}

Er is onderscheid gemaakt in vier funktiegroepen. Alle verpleegkundigen die geen leidinggevende funktie vervullen worden aangeduid als 'teamverpleegkundigen'. Waarnemend- afdelings- of unithoofden en hoofden worden resp. waarnemend hoofd en afdelingshoofd genoemd. Daarnaast zijn er afdelingshoofden die hoofd zijn van een aantal afdelingen. Deze zullen aangeduid worden als koördinerende afdelingshoofden.

Verpleegkundigen die als praktijkbegeleider of vaste nachtdienst, of op andere uitvoerende funkties werkzaam zijn, zijn ingedeeld als teamlid.

De gemiddelde leeftijd neemt toe met de hoogte van de funktie, hetgeen voor de hand ligt. Eveneens conform de verwachting is de afname van het aantal vrouwen naarmate de funktie hoger is (zie Tabel 4.4.). Dit patroon geldt voor alle zes de deelnemende instellingen.

Tabel 4.4. Funktie naar aantallen, gemiddelde leeftijd

en aantal mannen in procenten per sektor (1988)

\begin{tabular}{lrrrrrrr}
\hline & \multicolumn{3}{c}{ longstay } & \multicolumn{3}{c}{$\begin{array}{c}\text { shortstay } \\
\text { nem.lft } \% \text { man }\end{array}$} & n gem.lft \%man \\
\hline teamlid & 270 & 32 & 35 & 255 & 30 & 50 \\
watarnemend hoofd & 22 & 33 & 73 & 30 & 33 & 63 \\
afdelingshoofd & 56 & 38 & 71 & 37 & 38 & 81 \\
koordinerend hoofd & 8 & 43 & 88 & 12 & 43 & 75 \\
\hline totaal & 356 & 33 & 44 & 334 & 32 & 56
\end{tabular}

\section{Ervaring in de verpleging}

Men gaf op gemiddeld 7.5 jaar ervaring in de psychiatrische verpleging te hebben. De duur van de werkervaring van de verpleegkundigen verschilt tussen de instellingen. Voor de shortstay afdelingen is de totale ervaring gemiddeld 7.1 jaar $(F=2.38$ $\mathrm{p}<0.05$ ). Ook de gemiddelde ervaring op de longstay afdelingen verschilt tussen de instellingen. De totale ervaring is er gemiddeld 7.9 jaar $(F=3.27 p<0.01)$. 
Mannen hebben gemiddeld 8.9 jaar ervaring. Voor vrouwen is dat 6.1 jaar (zie Tabel 4.5). Het verschil wan bijna drie jaar ervaring in total tussen mannen en vrouwen is statistisch signifikant $(t=6.3 p<0.001)$

Tabel 4.5. Aantal jaren ervaring naar afdeling $(1988 ; n=690)$

\begin{tabular}{lcccccc}
\hline & $\begin{array}{c}\text { mannen } \\
\text { gem. (s.d.) }\end{array}$ & \multicolumn{2}{c}{$\begin{array}{c}\text { vrouwen } \\
\text { gem. (s.d.) }\end{array}$} & \multicolumn{2}{c}{$\begin{array}{c}\text { totaal } \\
\text { gem. (s.d.) }\end{array}$} \\
\hline shortstay & 8.3 & $(6.4)$ & 5.6 & $(5.1)$ & 7.1 & $(5.9)$ \\
longstay & 9.7 & $(6.9)$ & 6.5 & $(5.0)$ & 7.9 & $(6.1)$ \\
\hline totaal & 8.9 & $(6.6)$ & 6.1 & $(5.1)$ & 7.5 & $(6.1)$
\end{tabular}

\section{Opleidingen}

Tachtig procent van de respondenten heeft een B-opleiding gevolgd. Ruim een kwart van die tachtig procent, oftewel twintig procent van alle verpleegkundigen die aan het onderzoek deelgenomen hebben beschikt over zowel een diploma verpleegkunde $\mathbf{A}$ als B.

Acht procent van de deelnemers heeft een M.B.O.V. opleiding gevolgd, en vijf procent bezit een diploma van de H.B.O.V.

Een kleine groep $(7 \%)$ bezit geen van de hiervoor genoemde opleidingen, maar wel een diploma ziekenverzorging of een diploma verpleegkunde- $Z$ of alleen een Adiploma.

Verder komen alle denkbare kombinaties van basisopleidingen voor, zoals bijv. ziekenverzorging plus één van de verpleegkunde diploma's, of een diploma van een dagopleiding plus een diploma van een in-service opleiding.

Naast basisopleidingen hebben de respondenten ook andere opleidingen gevolgd. Het meeste gaat het daarbij om de kaderopleiding (en andere managementopleidingen) of de opleiding inrichtingswerk.

Van de deelnemers heeft $24 \%$ een kaderopleiding en $13 \%$ een andere verpleegkundige vervolgopleiding zoals, docentenopleiding, praktijkbegeleiding, alsook verpleegkundige specialismen gevolgd.

De opleiding inrichtingswerk is gevolgd door $11 \%$ van de deeinemers. Voor andere opleidingen, zoals psychotherapie, maatschappelijk werk, pedagogische akademie en m.o. pedagogiek, geldt dat bij elkaar 13\% van de deelnemers die gevolgd heeft. 


\subsection{Selektie van variabelen woor het onderzoek}

Voor de analyses zullen alleen funktie, ervaring, geslacht en het al dan niet gevolgd hebben van een opleiding inrichtingswerk gebruikt worden. De verantwoording daarvan werd in hoofdstuk 3 gegeven. In het kort zal dit nogmaals toegelicht worden, en aan de hand van de bevindingen op haalbaarheid ingeschat.

Funktie is van belang, aangezien werwacht mag worden dat taakopvattingen verband houden met de funktie die men bekleedt. Ofschoon het aantal jaren dat men werkzaam is samenhangt met de funktie $(r=0.53)$, geldt niet voor iedereen met een rume ervaring dat hij of zij op een leidinggevende funktie werkzaam is. Leeftijd blijft buiten beschouwing aangezien het verband tussen jaren ervaring en leeftijd tamelijk hoog is $(r=0.80)$. Uit de analyses van de persoonskenmerken blijkt dat er verbanden zijn tusgen geslacht en gemiddelde leeftijd en funktie. Het is aldus zinvol om geslacht in het onderzoek te betrekken, dat wil zeggen de bevindingen te kontroleren voor het mogelijke effekt van geslacht.

De opleiding inrichtingswerk is een sociaal-agogische opleiding die een aantal psychiatrisch verpleegkundigen gevolgd hebben na hun B-opleiding. In tegenstelling tot de verpleegkunde opleidingen is deze opleiding niet afgeleid van het medisch model. Het is daarom van belang om na te gaan of verpleegkundigen die deze opleiding gevolgd hebben verschillen in taakopvattingen van kollega's die niet in het bezit zijn van een diploma inrichtingswerk.

Verder zal bij de analyses nagegaan worden of er verschillen zijn naar de aard van de zorgverlening, dat wil zeggen de sektor waarin men werkzaam is.

\section{Samenvatting}

In dit hoofdstuk is de opzet van het hoofdonderzoek besproken. Dit onderzoek bestaat uit een schriftelijke enquête onder psychiatrisch verpleegkundigen, werkzaam in zes psychiatrische instellingen.

In totaal is door 898 verpleegkundigen wit zes instellingen deelgenomen aan het onderzoek. De respons bedraagt (in totaal) 78\%. Niet alle deelnemers werken op longstay of shortstay afdelingen, zoals die bedoeld zijn voor dit onderzoek. Dit betekent dat uiteindelijk 697 enquêtes gebruikt zullen worden voor de analyses.

Uit de analyses van de persoonskenmerken blijkt dat er verschillen zijn naar geslacht, leeftijd en opleidingen tussen de respondenten uit de twee sektoren. Mannen zijn iets ouder dan vrouwen, en verpleegkundigen werkzaam op longstay-afdelingen zijn gemiddeld ouder dan verpleegkundigen die in shortstay-afdelingen werken. Ook zijn er verschillen in persoonskenmerken tussen verpleegkundigen die in de deelnemende instellingen werkzaam zijn. Voor de analyses zal van de achtergrondkenmerken alleen funktie, geslacht, aantal jaren ervaring en het bezitten van een diploma inrichtingswerk als verklarende variabele beschouwd worden. 


\section{TAAKOPVATTINGEN}

\section{Inleiding}

In dit hoofdstuk worden de taken van psychiatrisch verpleegkundigen behandeld. Het gaat daarbij om de (ervaren) feitelijkheid en de wenselijkheid ten aanzien van een aantal aktiviteiten die psychiatrisch verpleegkundigen verrichten. Aan bod komen zowel de relatieve tijdsbesteding en de voldoening van de aktiviteiten als de frekwenties.

Uiteraard zal uitgelegd worden hoe de taken gemeten zijn en hoe deze onderverdeeld zijn in een aantal subgroepen. Tenslotte wordt nagegaan of er verbanden zijn tussen achtergrondkenmerken van de respondenten en de taakopvattingen.

\subsection{Tijdsbesteding}

Aan de respondenten werd gevraagd een ordening naar tijdsbesteding aan te geven. Uit die ordening blijkt dat men de minste tijd besteedt aan begeleiding bij het huishouden. Aan kontakten met kollega's en/of andere disciplines daarentegen zegt men de meeste tijd te besteden; nog meer dan aan gezamenlijke aktiviteiten met patiënten, of het voeren van begeleidende gesprekken (zie Tabel 5.I.).

Tabel 5.1. Gemiddlelde relatieve tijdsbesteding $(n=697)$

\begin{tabular}{lcccccc}
\hline & longstay & shortstay & \multicolumn{2}{c}{ t.*) } & \multicolumn{2}{c}{ totaal (s.d) } \\
\hline kontakten met kollega's en/of andere disciplines & 3.5 & 4.1 & & 5.19 & 3.8 & $(1.5)$ \\
gezamenlijke aktiviteiten met patiënten & 3.5 & 3.7 & & n.s. & 3.6 & $(2.0)$ \\
begeleidende gesprekken & 3.2 & 3.9 & 4.93 & 3.5 & $(1.8)$ \\
begeleiding bij persoonlijke verzorging & 4.1 & 2.7 & 9.36 & 3.4 & $(2.1)$ \\
informatie verstrekken en verkrijgen (m.b.t. pat.) & 3.0 & 3.9 & 7.27 & 3.4 & $(1.7)$ \\
betgeleiding bij huishouden & 2.9 & 2.0 & 7.36 & 2.5 & $(1.8)$ \\
\hline
\end{tabular}

*) t-waarde, signifikant bij $p<0.001$

De relatieve tijdsbesteding verschilt tussen de sektoren. In de shortstay besteedt men de meeste tijd aan kontakten met kollega's en informatie uitwisselen over patiënten. In de longstay wordt de meeste tijd besteed aan persoonlijke verzorging van patiënten. In beide sektoren wordt de minste tijd besteed aan begeleiding bij het huishouden. 
In een onderzoek onder leerling-verpleegkundigen werd nagegaan welke prioriteiten leerlingen gaven aan aktiviteiten (Van der Hoop, 1973). Het voeren van gesprekken had de hoogste prioriteit. Aktiviteiten met betrekking tot 'lichamelijke verzorging en persoonlijke verzorging" hadden de laagste prioriteit. Dit patroon komt niet overeen met de ordening van de aktiviteiten naar tijdsbesteding uit Tabel 5.1. In de volgende paragraaf zal nagegaan worden of dit patroon wel tot uitdrukking komt bij het verschil in feitelijkheid en wenselijkheid met betrekking tot de taken van psychiatrisch verpleegkundigen.

\subsection{Het meten van de taakopvattingen}

\section{Konstruktie van de meetschaal}

Zoals uit de vorige paragraaf bleek werd bij het onderzoek naar de taken uitgegaan van een indeling in zes kategorieën van aktiviteiten. Voor het bepalen van de vragen voor de enquête werd een selektie gemaakt uit de aktiviteiten die de verpleegkundigen tijdens de interviews noemden. Per aktiviteit is door de respondenten aangegeven hoe vaak deze verricht wordt en hoe vaak men vindt dat de aktiviteit verricht moet worden. Bijvoorbeeld:

Hoe vaak helpt u patiënten bij het wassen en aankledlen? n.v.t. / nooit / zelden / soms / waak / erg vaak

Hoe vaak vindt $u$ dat $u$ dit moet doen? n.v.t. / nooit / zelden / soms / vaak / erg vaak

Op de onderzoeksgegevens is een faktoranalyse (principale komponentenanalyse) toegepast op beide metingen: de feitelijke en de wenselijke taakopvattingen ${ }^{1}$ ). Een indeling in vijf faktoren geeft voor beide metingen exakt dezelfde groepen weer. Daarbij is sprake van én sterke faktor (eigenwaarde feitelijk 8.9; wenselijk 10.2) en een duidelijke tweede faktor (eigenwaarde feitelijk 4.7; wenselijk 4.3). De eerste faktor omvat aktiviteiten met betrekking tot persoonlijke zorg, de tweede omvat items over begeleidende gesprekken. Aangezien de overige faktoren (eigenwaarden tussen 2.6 en 1.3) inhoudelijk betekenisvol zijn, is besloten om in eerste instantie de taken te bestuderen aan de hand van vijf faktoren. De bij het uittesten van de lijst bekende faktoren: kontakten met kollega's en/of andere disciplines, en informatie verstrekken en verkrijgen met betrekking tot de patiënt, blijken bij de definitieve indeling één faktor te vormen. Het gaat nu dus om vijf faktoren:

1) De faktortabel met de bijbehorende gegevens over de faktoranalyse is opgenomen in Bijlage C. 


$\begin{array}{ll}\text { - } & \text { persoonlijke zorg; } \\ \text { - } & \text { begeleidende gesprekken; } \\ \text { - } & \text { begeleiding bij huishouden; } \\ \text { - } & \text { gezamenlijke aktiviteiten; } \\ \text { - } \quad \text { informeren \& koördineren. }\end{array}$

Niet alle vragen maken deel uit van deze faktoren. Enkele vragen zijn buiten beschouwing gelaten, omdat alle respondenten nagenoeg betzelfde antwoord gaven. Bijvoorbeeld met patiënten naar film of feest gaan ( $2 \%$ van de respondenten als vaak of erg vaak aangegeven), of koffie drinken met patiënten (80\% vaak en erg vaak). Andere vragen zijn kennelijk van andere orde en zijn daardoor buiten de faktoren gebleven. Dit geldt bijvoorbeeld voor een vraag over medicijnen toedienen en een vraag over het bijhouden van financiën voor patiënten. Dit wil niet zeggen dat deze aktiviteiten van minder belang zouden zijn. Het aantal items dat in de enquête opgenomen werd met betrekking tot deze aktiviteiten was in ieder geval te gering om een faktor te kunnen vormen. Dat heeft wellicht te maken met het feit dat (bijvoorbeeld wat betreft medicijnen toedienen) wel door de geïnterviewden op die aktiviteiten gewezen werd, doch niet aan de hand van diverse uitspraken.

\section{Frekwenties van de aktiviteiten in feitelijkheid en wenselijkheid}

Alvorens nader ingegaan wordt op de konstruktie van de aktiviteitenschalen, zal eerst de frekwentie in feitelijkheid en wenselijkheid besproken worden. Daarbij wordt gebruikt gemaakt van de indeling in de vijf faktoren. Per faktor wordt van alle aktiviteiten aangegeven hoeveel respondenten deze vaak danwel weinig verrichten en in welke mate zij deze naar hun zeggen minder danwel vaker behoren te doen.

Begeleidende gesprekken is de meest voor de hand liggende benaming voor de eerste faktor. Alle vragen hebben betrekking op het voeren van gesprekken met patiênten. De strekking van de vragen verschilt van informatie inwinnen tot het geven van informatie en het houden van vertrouwelijke gesprekken.

Ruim zestig procent van de respondenten geeft (gemiddeld) aan dat zij waak of erg vaak begeleidende gesprekken voeren. Al deze gesprekken zou men bij voorkeur vaker houden; dat wil zeggen dat het aantal respondenten dat vindt dat zij deze aktiviteiten vaker zouden moeten verrichten groter is dan het aantal dat van mening is dat de aktiviteiten minder vaak gedaan zou moeten worden (zie Tabel 5.2.). 
Tabel 5.2. Begeleidende gesprekken in procenten $(n=697)$

\begin{tabular}{|c|c|c|c|c|c|c|}
\hline & & $\begin{array}{l}\text { nooit } \\
\text { zelden }\end{array}$ & soms & $\begin{array}{l}\text { vaak } \\
\text { erg vaak }\end{array}$ & minder & vaker \\
\hline 1. & praten met pat.ondat er iets is & 2 & 21 & 78 & 6 & 13 \\
\hline 2. & praten over wensen van pat. & 4. & 30 & 66 & 7 & 20 \\
\hline 3. & belaing aktiv.uitleggen & 8 & 27 & 65 & 13 & 18 \\
\hline 4. & praten over gevoelens en emoties & 5 & 32 & 64 & 4 & 21 \\
\hline 5. & praten over akt. van pat. & 6 & 31 & 63 & 7 & 16 \\
\hline 6. & praten over spanning \& moeilijkh. & 6 & 34 & 61 & 7 & 18 \\
\hline 7. & vertrouw gesprek met patiënten & 5 & 38 & 56 & 6 & 20 \\
\hline 8. & pat. stimul over pers. probl. prat & 7 & 45 & 48 & 4 & 17 \\
\hline \multirow[t]{2}{*}{9.} & informeren naar daginvulling pat. & 14 & 41 & 45 & 4 & 30 \\
\hline & gemiddeld & 6 & 33 & 61 & 6 & 19 \\
\hline
\end{tabular}

Het agogisch handelen is per definitie een wezenlijke komponent van het beroep van psychiatrisch verpleegkundige. In hoofdstuk twee is beschreven dat dit de werkvorm is die aangewend wordt voor het begeleiden van patienten; bijvoorbeeld wat betreft het stimuleren van patiënten om voor zichzelf te zorgen. De begeleidende taak van de psychiatrisch verpleegkundige hangt samen met de veranderde opvattingen over de zorgverlening aan de chronische patiënt (zie hfdst. 1.). Het is juist deze taak die de psychiatrische verpleging onderscheidt van bijwoorbeeld de verpleging in de algemene ziekenhuizen. In die lijn is te verwachten dat de profilering van de psychiatrische verpleging vooral gericht is op het aksentueren van de agogisch begeleidende taken. De bevindingen uit Tabel 5.2 . bevestigen dit beeld.

De benaming persoonlijke zorg lijkt het beste van toepassing op de volgende faktor. Aangetekend dient daarbij wel te worden, dat het gaat om persoonlijke zorg in ruime zin. Het betreft items over lichamelijke verzorging, kleding, slapen, maar ook over maaltijden en de zorg daaromtrent.

Gemiddeld wordt door $41 \%$ van de respondenten aangegeven dat zij aktiviteiten met betrekking tot persoonlijke zorg vaak of erg vaak doen (zie Tabel 5.3.). Tussen de aktiviteiten onderling zijn er echter grote verschillen in frekwentie. Zo zegt $71 \%$ van de respondenten er vaak op toe te zien dat patiënten naar aktiviteiten gaan. Slechts $17 \%$ van de respondenten bepaalt wat voor kleding de patiënten dragen. Voor deze aktiviteiten geldt dat het percentage dat deze minder vaak wil verrichten beduidend groter is dan het aantal respondenten dat de aktiviteiten vaker wil doen. Dit is overeenkomstig de eerder beschreven anti-hospitalisatiegedachte, waaruit afgeleid is dat persoonlijke zorg bij voorkeur minder door verpleegkundigen gedaan zou dienen te worden. Hierbij dient wel aangetekend te worden dat de meerderheid van de respondenten geen verandering in frekwentie van persoonlijke zorg aktiviteiten wenselijk acht. 
Tabel 5.3. Persoonlijke zorg in procenten $(1988 ; \mathrm{n}=697)$

\begin{tabular}{|c|c|c|c|c|c|c|}
\hline & & $\begin{array}{l}\text { nooit } \\
\text { zelden }\end{array}$ & soms & $\begin{array}{l}\text { vaak } \\
\text { erg vaak }\end{array}$ & minder & vaker \\
\hline 1. & toezien dat pat.naar akt. gaan & 15 & 14 & 71 & 45 & 2 \\
\hline 2. & begl. wakker worden en opstaan & 18 & 20 & 62 & 40 & 2 \\
\hline 3. & toezien niet te vroeg gaan slapen & 21 & 25 & 54 & 31 & 6 \\
\hline 4. & begl broodmaalijjden & 31 & 26 & 42 & 23 & 9 \\
\hline 5. & helpen op/afruimen tafel & 27 & 33 & 39 & 40 & 3 \\
\hline 6. & begeleiden bij afwas & 32 & 31 & 38 & 32 & 4 \\
\hline 7. & begl. wassen en aankleden & 35 & 29 & 36 & 21 & 5 \\
\hline 8. & begl. baden en douchen & 32 & 32 & 36 & 17 & 11 \\
\hline 9. & begeleiden pat.naar aktivit. & 36 & 33 & 32 & 24 & 10 \\
\hline 10. & begl. opmaken en verschonen bed & 41 & 34 & 26 & 24 & 6 \\
\hline 11. & bepalen kleding patiënten & 51 & 32 & 17 & 27 & 6 \\
\hline & gemido & 31 & 28 & 41 & 29 & 6 \\
\hline
\end{tabular}

De derde faktor kreeg de benaming koördinatie $\&$ informatie. Het betreft vragen die betrekking hebben op het regelen van zaken vór de patiënt en het onderhouden van kontakten met derden over de patiënt.

Tabel 5.4. Informatie \& koördinatie aktiviteiten in procenten $(n=697)$

\begin{tabular}{lllllll}
\hline & & $\begin{array}{l}\text { nooit } \\
\text { zeliden }\end{array}$ & soms & $\begin{array}{l}\text { vaak } \\
\text { erg vaak }\end{array}$ & minder & vaker \\
\cline { 1 - 5 } 1. & kontakten andere disciplines & 9 & 25 & 66 & 8 & 11 \\
2. & zorgverl. koörd. voor patiënten & 12 & 24 & 63 & 10 & 17 \\
3. & kontakten familieleden & 15 & 47 & 38 & 4 & 33 \\
4. & gesprekken met familie & 21 & 52 & 27 & 4 & 38 \\
5. & familie inform.over patiënten & 28 & 45 & 27 & 6 & 26 \\
6. & kontakten externe instant. discipl. & 42 & 40 & 18 & 3 & 31 \\
\hline & gemiddeld & 21 & 39 & 40 & 35 & 26
\end{tabular}

Van deze aktiviteiten zegt gemiddeld $40 \%$ van de respondenten dat zij ze vaak of erg vaak verrichten. De frekwentie tussen de aktiviteiten onderling verschilt (zie Tabel 5.4.). Het aantal respondenten dat de aktiviteiten vaker zegt te willen doen is groter dan het aantal dat de aktiviteiten minder vaak wil doen. Ook hier geldt, evenals bij de vorige aktiviteiten, dat de meerderheid geen behoefte aangeeft tot wijziging van de frekwentie. 
Begeleiding huishouden omvat enkele vragen die betrekking hebben op aktiviteiten van huishoudelijke aard die geen dagelijks karakter hebben en zo mogelijk ook door bijvoorbeeld de huishoudelijke dienst gedaan zouden kunnen worden. Het gaat om schoonhouden van kamers tot het kopen van levensmiddelen.

Tabel 5.5. Begeleiding huishouden in procenten $(n=697)$

\begin{tabular}{llccccc}
\hline & & $\begin{array}{c}\text { nooit } \\
\text { zelden }\end{array}$ & soms & $\begin{array}{c}\text { vaak } \\
\text { erg vaak }\end{array}$ & minder & vaker \\
\hline 1. & begl. onderhoud gemeensch. ruimten & 38 & 30 & 32 & 18 & 17 \\
2. & begl. onderhoud kamers & 35 & 35 & 30 & 19 & 19 \\
3. & begl. verzorgen wassen kleding & 42 & 35 & 23 & 18 & 15 \\
4. & kopen levensmidd.voor maaltijden & 77 & 13 & 10 & 4 & 22 \\
\hline & gemiddeld & 48 & 48 & 24 & 15 & 18
\end{tabular}

Gemiddeld zegt $24 \%$ van de respondenten vaak begeleiding bij huishouden te geven. Alleen levensmiddelen kopen voor maaltijden zou men meer willen doen. Wat betreft zaken die het schoonmaken betreffen, is het aantal respondenten dat die minder zouden willen doen min of meer gelijk aan het aantal dat die aktiviteiten vaker zou willen doen (zie Tabel 5.5.).

Gezamenlijk aktiviteiten variëren van wandelen met patiënten tot het begeleiden bij het doen van boodschappen voor privé gebruik van patiënten. Het gemeenschappelijke element is het gezamenlijk met de patiënt dingen doen. Expressief gedrag vormt naast het agogisch handelen een deel van de taken van psychiatrisch verpleegkundigen (Van Eeden, 1982). Bedoeld wordt daarmee het samen dingen doen, zonder dat een hoger doel (begeleiding) voorop staat.

Tabel 5.6. Gezamenlijke aktiviteiten in procenten $(n=697)$

\begin{tabular}{lllcccr}
\hline & & $\begin{array}{l}\text { nooit } \\
\text { zelden }\end{array}$ & soms & $\begin{array}{c}\text { vaak } \\
\text { erg vaak }\end{array}$ & minder & vaker \\
\hline 1. & wandelen met patiënten & 29 & 48 & 25 & 4 & 38 \\
2. & gezelschapspel. met patiënt. & 27 & 48 & 25 & 4 & 38 \\
3. $\quad$ met pat. naar stad of dorp gaan & 39 & 44 & 17 & 3 & 7 \\
4. $\quad$ boodschappen voor prive gebruik & 44 & 43 & 13 & 6 & 25 \\
\hline & 35 & 46 & 20 & 4 & 27
\end{tabular}


Gemiddeld zegt $20 \%$ van de respondenten de gezamenlijke aktiviteiten vaak te verrichten. Het aantal respondenten dat deze aktiviteiten vaker wil doen is groter dan het aantal dat de aktiviteiten minder vaak zou willen doen. De meerderheid houdt het evenwel op de frekwentie waarin de aktiviteiten gedaan worden (zie Tabel 5.6.).

\section{Algemene opmerkingen bij de aktiviteiten}

Hoewel voor alle aktiviteiten geldt dat de meeste respondenten deze in gelijke mate doen als zij vinden dat zij die behoren te doen, is het algemene patroon: minder aan persoonlijke zorg en meer aan begeleidende gesprekken en gezamenlijke aktiviteiten doen. Vergelijkbaar met dit patroon is een onderzoek naar taakopvattingen van verpleegkundigen in algemene ziekenhuizen. Uit dat onderzoek bleek dat verpleegkundigen minder aan lichamelijke zorg van patiënten wilden doen en meer aan psycho-sociale begeleiding. Het meest wilde men af van het huishoudelijk werk (De Vries-Griever, 1987). Uit beide onderzoeken (dat van De Vries-Griever en het onderhavige) blijkt dat verpleegkundigen minder aan persoonlijke zorg zouden willen doen, zij het dat persoonlijke zorg in het ziekenhuis neerkomt op lichamelijke zorgverlening en in de psychiatrische instellingen op alledaagse aktiviteiten in ruimere zin.

Een andere parallel betreft de wens om meer aan psycho-sociale begeleiding te doen. Psychiatrisch verpleegkundigen willen meer aan begeleidende gesprekken doen, hetgeen gerekend kan worden tot psycho-sociale begeleiding.

Anders ligt het met huishoudelijk werk. Psychiatrisch verpleegkundigen willen dit, althans gemiddeld, niet minder doen. Het ontbreken van overeenkomst met het onderzoek van De Vries-Griever en dit onderzoek aksentueert het verschil tussen de verpleging in het algemeen ziekenhuis en in de psychiatrische instelling. Huishoudelijk werk is voor de psychiatrisch verpleegkundige geen doel op zich, doch een middel om te participeren in het woonmilieu van de patiënten. In algemene ziekenhuizen is huishoudelijk werk niet meer dan dat. Het wordt ongetwijfeld niet samen met de patiënten verricht.

De resultaten van het onderzoek van De Vries-Griever zijn opmerkelijk, ondat eruit blijkt dat verpleegkundigen in algemene ziekenhuizen een deel van wat juist als kenmerk van hun taken gezien wordt, de lichamelijke verzorging, liever minder willen doen. Voor de psychiatrisch verpleging geldt deze konstatering ook, maar heeft wellicht een andere betekenis. Het verrichten van aktiviteiten op het vlak van persoonlijke zorg dient immers, uitgaande van de anti-hospitalisatiegedachte, zoveel mogelijk beperkt te worden. Anders gesteld: de antwoorden van de psychiatrisch verpleegkundigen dienen gezien te worden in het licht van een bepaaldle beroepshouding die van hen verwacht wordt. 
Daarbij kan dan wel een kanttekening geplaatst worden omtrent de vraag of het niet toevallig gewoon goed witkomt dat in het kader van de anti-hospitalisatiegedachte 'minder leuke dingen' ook niet gedaan hoeven worden. Daar staat evenwel tegenover dat datgene wat de beroepswoldoening bepaalt, samenhangt met datgene wat maatschappelijk werwacht wordt dat men zou moeten doen (Mok, 1973). Van psychiatrisch verpleegkundigen wordt nou eenmaal verwacht dat zij het aksent leggen op begeleiding in agogische zin; en dat zij de patiënt zoveel mogelijk vrij laten in zijn alledaagse doen (zie hoofdstuk 1 ).

\section{Betrouwbaarheid van de meetschaal}

De interne konsistentie van de faktoren is bepaald via het berekenen van de Cronbachs alfa koëfficiënt. De meeste alfa's zijn hoger dan 0.80 (zie Tabel 5.7.). Bij persoonlijke zorg is dat zelfs 0.91 . Bij het konstrueren van schalen is homogeniteit daarvan een vereiste. Een lage alfa-waarde is dan niet gewenst. De alfa's van de faktoren zijin bij de aktiviteitenschalen aan de (te) hoge kant. Dit zou kunnen wijzen op de aanwezigheid van een antwoordtendentie. Alvorens daar verder op in te gaan zal eerst de samenhang tussen de faktoren behandeld worden.

Tabel 5.7. Schaalwaarden aktiviteiten

\begin{tabular}{lccccccc}
\hline & \multicolumn{3}{c}{ feitelijk } & \multicolumn{3}{r}{ wenselijk } & \multicolumn{2}{c}{ Pearson } \\
& gem. & (s.d.) & alfa & gem. & (s.d.) & alfa & r. $^{*}$ ) \\
\hline persoonlijke zorg & 3.1 & $(.81)$ & .91 & 2.8 & $(.80)$ & .91 & .77 \\
begeleiding huishouden & 2.5 & $(.82)$ & .71 & 2.6 & $(.87)$ & .77 & .74 \\
begeleidende gesprekken & 3.6 & $(.57)$ & .89 & 3.8 & $(.58)$ & .89 & .77 \\
gezamenlijke aktiviteiten & 2.8 & $(.77)$ & .80 & 3.2 & $(.88)$ & .86 & .77 \\
koördinatie \& informatie & 3.2 & $(.67)$ & .81 & 3.5 & $(.64)$ & .82 & .88 \\
\hline
\end{tabular}

*) Korrelaties tussen feitelijkheid en wenselijkheid

De subschalen onderling vertonen samenhang, hetgeen voor de hand ligt, er is namelijk sprake van dimensies van één taakgebied, die in de praktijk niet volledig te scheiden zijn. Wel is het mogelijk om in meer theoretische zin onderscheid aan te brengen tussen groepen van gelijksoortige aktiviteiten. Dit blijkt ook uit de samenhang tussen de subschalen onderling (zie Tabel 5.8.).

Zowel voor de meting van de feitelijke taken als de wenselijke taken bestaat er samenhang tussen de subschalen persoonlijke zorg en begeleiding huishouden met gezamenlijke aktiviteiten bij een Pearson koëfficiënt van $>0.50$. Tussen de overige subschalen is eveneens samenhang, doch in mindere mate. Dit bevestigt dat, zoals 
reeds gesteld, sprake is van dimensies die wel te onderscheiden zijn, doch niet geheel van elkaar te scheiden. De taken zijn niet onafhankelijk van elkaar.

Tabel 5.8. Samenhang tussen de subschalen *)

\begin{tabular}{llllll}
\hline feitelijk & $\begin{array}{l}\text { pers. } \\
\text { zorg }\end{array}$ & $\begin{array}{l}\text { huish. } \\
\text { begl. }\end{array}$ & $\begin{array}{l}\text { begl. } \\
\text { gespr. }\end{array}$ & $\begin{array}{l}\text { geza. } \\
\text { akt. }\end{array}$ & $\begin{array}{l}\text { koörd. } \\
\text { info. }\end{array}$ \\
\hline persoonlijke zorg & & 0.52 & 0.28 & 0.62 & 0.27 \\
huishoud. begeleiding & 0.46 & & 0.42 & 0.57 & 0.27 \\
begeleidende gesprek. & 0.16 & 0.39 & & 0.49 & 0.39 \\
gezamenlijke aktivit. & 0.59 & 0.51 & 0.41 & & 0.34 \\
koördinatie \& inform. & 0.24 & 0.22 & 0.33 & 0.23 & \\
\hline
\end{tabular}

*) Alle korrelaties zijn signifikant bij $p \leq 0.01$

De samenhang tussen de subschalen kan echter ook een andere oorzaak hebben. Eir zou sprake kunnen zijn van een antwoordtendentie, namelijk de neiging van alle aktiviteiten aan te geven dat men deze vak, danwel weinig doet. De Cronbach alfawaarden zijn aan de hoge kant, hetgeen eveneens wijst in de richting van een antwoordtendentie. Ter kontrole zijn daarom ook de alfa's wan de hele schaal berekend. Deze zijn voor de meting van de feitelijkheid 0.90 en voor de meting van de wenselijkheid 0.91. Deze hoge waarden wijzen inderdaad in de richting van de aanwezigheid van een antwoordtendentie. Daarom dient rekening gehouden te worden met de aanwezigheid van een storende faktor, die de validiteit van het instrument bedreigt. De aanwezigheid van zo'n storende faktor leidt tot effekten bij de afhankelijke variabele, die dan ten onrechte toegeschreven worden aan de verklarende variabelen (Nederhof, 1981). Er is dus sprake van een serieus probleem, waarvoor een oplossing gevonden moet worden. Die oplossing is mogelijk door de skores op de faktoren te kombineren met de opgave van de relatieve tijdsbesteding per aktiviteitengroep. Op die wijze ontstaat dan een gewogen taakopvatting, bestaande uit de tijdsbesteding en de frekwentie van de aktiviteiten. Daartoe is het wel van belang dat beide metingen niet exakt hetzelfde meten. Ter kontrolle daarwoor zijn daarom de onderlinge korrelaties tussen de korresponderende aktiviteiten berekend (zie Tabel 5.9.). 
Tabel 5.9. Pearson korrelaties relatieve tijdsbesteding en faktoren fieiteligke tak kopvatingen ")

persoonlijke zorg

begeleiding huishouden

beigeleidende gesprekken

gezamenlijke aktiviteiten

informatie \& koördinatie
.59

.35

.35

.37

$.21^{*}$ )

*) $p<0.001$ **) deze schaal is gekombineerd met "informatie verstrekken en verkrijgen' wan de relatieve tijdsbesteding

Deze korrelaties zijn, hoewel soms signifikant, niet dermate hoog dat verondersteld moet worden dat precies hetzelfde gemeten is.

Om de antwoordtendenties te korrigeren, kunnen de antwoorden op de items over de tijdsbesteding en de faktoren gekombineerd worden. Dit houdt in dat een respondent alleen een skore "hoog' krijgt toegewezen, wanneer deze bij beide metingen een overeenkomstig antwoord in die richting geeft. Voor het bepalen van de grens tussen hoge en lage skores is uitgegaan van de mediaan. Skores kleiner of gelijk aan de mediaan worden als laag, en skores groter dan de mediaan als hoog gewaardeerd. Op deze wijze ontstaat een kombinatie van de frekwenties en de relatieve tijdsbesteding van de aktiviteiten. In Figuur 5.1. wordt verduidelijkt hoe de skores opnieuw samengesteld zijn.

Figuur 5.1. Samenstelling skores gewogen taakopwattingen

A

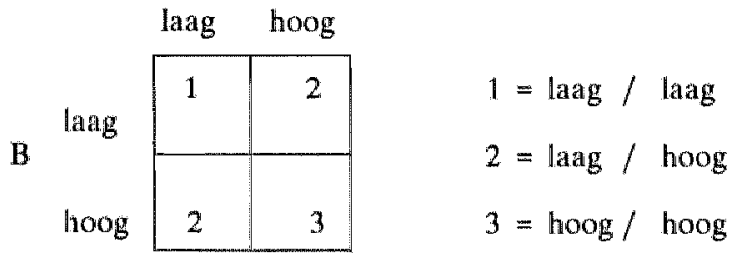

A. Skores op de relatieve tijdsbesteding

B. Skores uit de frelkwenties van de faktoren

Op deze wijze is een nieuwe antwoordschaal ontstaan, met skores variërend van 1 tot 3, resp. laag, laag/hoog, en hoog. Laag wil uiteraard zeggen dat de aktiviteit weinig gedaan wordt en hoog dat de aktiviteit veel gedaan wordt. 
Het onderling vergelijken van de samengestelde schalen is nu niet meer mogelijk, aangezien de konstruktie ervan uitgaat van de mediaanwaarden. Wel zijn de schalen geschikt om na te gaan wat de samenhang met andere variabelen is. In Tabel 5.10. wordt de verdeling van de aktiviteiten weergegeven.

Bij begeleiding persoonlijke zorg komen de relatieve tijdsbesteding en de skores op de afzonderlijke vragen het meeste overeen. De kategorie hoog/laag is hier namelijk relatief het kleinste. Voor begeleiding huishouden geldt het tegengestelde beeld: de groep hoog/laag is daar het grootste.

Tabel 5.10. Verdeling van de gewogen aktiviteiten volgens Figuar 5.1. in procenten

\begin{tabular}{llll}
\hline & laag & laag/hoog hoog \\
\hline persoonlijke zorg & 33 & 27 & 40 \\
koördinatie \& informatie & 29 & 42 & 28 \\
begeleiding huishouden & 23 & 40 & 38 \\
begeleidende gesprekken & 21 & 38 & 41 \\
gezamenlijke aktiviteiten & 19 & 36 & 45 \\
\hline
\end{tabular}

Aanleiding tot het samenstellen van de nieuwe schalen was onder andere de samenhang tussen de subschalen. In Tabel 5.11. wordt daarom de samenhang van de gewogen taakopvattingen weergegeven. Daaruit blijkt dat nu sprake is van negatieve samenhang tussen persoonlijke zorg met gezamenlijke aktiviteiten $(r=-.21$ ) en koördinatie \& informatie $(r=-.17)$.

Tabel 5.11. Samenhang tussen de gewogen taakopvattingen (Pearson korrelaties)

\begin{tabular}{lllll}
\hline & $\begin{array}{l}\text { pers. } \\
\text { zorg }\end{array}$ & $\begin{array}{l}\text { huish. } \\
\text { begl. }\end{array}$ & $\begin{array}{l}\text { begl. gespr. } \\
\text { geza. } \\
\text { akt. }\end{array}$ \\
\hline begeleiding huishouden & $.29^{*}$ & & & \\
begeleidende gesprekken & $.11^{*}$ & $.14^{*}$ & & \\
gezamenlijke aktiviteiten & $-.21^{*}$ & .02 & $.15^{*}$ & \\
koördinatie \& informatie & $-.17^{*}$ & $-.13^{*}$ & $-.15^{*}$ & .06 \\
\hline
\end{tabular}

*) Signifikant bij $p \leq 0.01$

\section{Konsekwenties van de antwoordtendentie voor de analyses}

Eén van de doelstellingen van dit onderzoek is het bestuderen van de wenselijkheid van het uitvoeren van de aktiviteiten. De gesignaleerde antwoordtendentie maakt een verdere bestudering daarvan echter niet goed mogelijk. Immers daartoe zouden beide metingen (wenselijkheid en feitelijkheid) van elkaar afgetrokken moeten worden. Een 
algemeen bezwaar daarbij is dat wenselijkheid en feitelijkheid veelal niet geheel los van elkaar staan. De feitelijkheid beïnvloedt de wenselijkheid (Thierry \& KoopmanIwema, 1984). Ook in het onderhavige onderzoek blijken feitelijkheid en wenselijkheid hoog te korreleren.

Een andere beperking is dat een deel van de oorspronkelijke waarden verloren gaat. Zo kan de verschilskore 1 op vier manieren tot stand komen. De betekenis daarvan is evenwel niet gelijk. Iets erg vaak doen doch waak willen doen is immers niet gelijk aan iets weinig doen en nooit willen doen. In beide situaties zal de verschilskore 1 zijn. Afgezien van deze technische bezwaren, die op zich niet onoverkomelijk zouden zijn, speelt de antwoordtendentie hier parten. De ervaren feitelijkheid is namelijk opnieuw gekonstrueerd, omdat er een antwoordtendentie bleek te bestaan. Bij het samenstellen van de nieuwe schaal is de oorspronkelijke (feitelijkheids-) meting betrokken. Diezelfde meting zou ook deel uitmaken van de verschilskore. Dit betekent dat eenzelfde variantie van beide metingen: de gewogen feitelijkheid en de samen te stellen verschilskores, deel uit zou maken. Het met elkaar vergelijken van de schalen is dan weinig zinvol te noemen. Daarbij geldt ook nog dat de oorspronkelijke meting van de feitelijkheidl en de wenselijkheid van de aktiviteiten tamelijk hoog blijken te korreleren (zie Tabel 5.7.).

De wenselijkheidsmeting dient derhalve beperkt te blijven tot de reeds behandelde verschillen tussen de eigenlijke items (zie Tabellen 5.2.t/m 5.6.). De taakopvattingen zijn voor het meer analytische deel van dit onderzoek daarom beperkt tot de (erwaren) feitelijkheid, waarbij gebruik gernaakt wordt van de gewogen taakopvatting.

\section{Definitieve bepaling van de taakopvattingen voor de verdere analyses}

Aan het begin van dit hoofdstuk werd reeds gerefereerd aan de indeling in taakaspekten van Kramer. Een vergelijking van die aspekten met de indeling van Van Bergen en Hollands werd in hoofdstuk 2 besproken. Het betrof een indeling in instrumenteel technisch, agogisch en koördinerende aspekt. Alvorens verder te gaan met de analyses van de taakopvattingen, zal nagegaan worden of deze indeling bevestigd kan worden middels faktoranalyse. Daartoe zijn de vijf gewogen taakopvattingen opgenomen in een principale komponentenanalyse op drie faktoren. De verwachte taakaspekten worden inderdaad aangetroffen (zie Tabel 5.12.).

Een reden van technische aard om deze faktoranalyse uit te voeren is de mogelijkheid om gebruik te maken van faktorskores als schaalwaarden. Faktorskores geven namelijk van elkaar onafhankelijke faktoren. Aangezien de drie te verklaren variabelen samenhang vertonen, is het gebruik van faktorskores gewenst bij de verdere analyses van de taakopvattingen. 
Tabel 5.12. Faktoranalyse gewogen takopvathingen

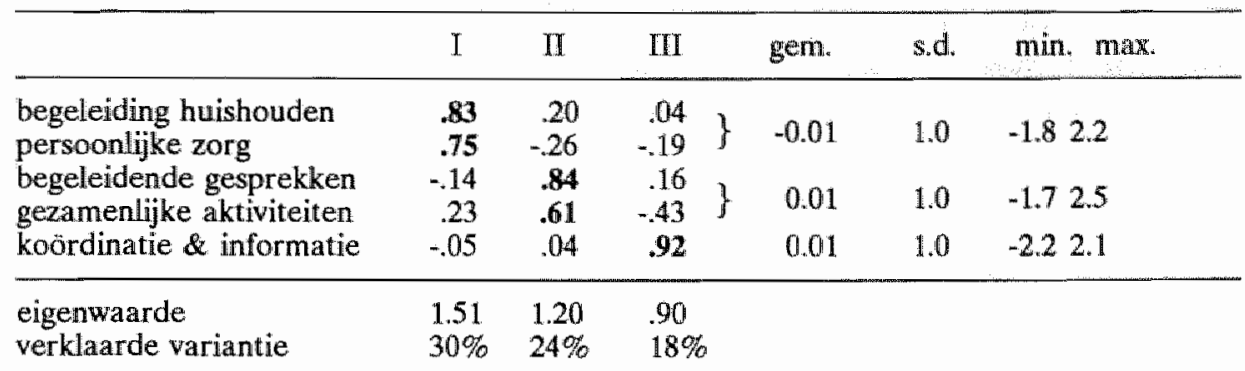

De eerste faktor bestaat uit begeleiding huishouden en persoonlijke verzonging. Dit heeft enige overeenkomst met het instrumenteel-technische aspekt, zoals dat bedoeld is door Van Bergen \& Hollands. Bij de definiëring van dit aspekt omschrijven de auteurs instrumenteel-technisch als :

(...) een technologie, gericht op een zo effektief en zo efficiënt mogelijk handelen met betrekking tot het beter maken of het behoeden voor zieker worden van de zieke mens.

(Van Bergen \& Hollands, 1978; blz. 71)

Volgens die omschrijving lijkt er geen sprake van overeenkomst met de eerste faktor. De overeenkomst blijkt wel uit de operationalisering van dit aspekt door de auteurs. Vergelijk daarbij bijvoorbeeld een van de items uit het meetinstrument voor het bepallen van de kwaliteit van de verpleegkundige zorg:

Een patiënt die dit niet zelf kan, moet geholpen worden om de nagels van $z$ 'n handen en voeten te verzorgen.

(Van Bergen, e.a. 1980; blz. 83)

Hoewel er een parallel getrokken kan worden met het instrumenteel-technische aspekt, lijkt de benaming persoonlijke zory ten behoeve van alledaagse aktiviteiten toch passender voor de eerste faktor. In het verloop van dit onderzoek zal dit aangeduid worden alls zorggerichtheid.

De tweede faktor bestaat uit begeleidende gesprekken en gezamenlijke aktiviteiten. In zekere zin is dit een kombinatie van de agogisch begeleidende en van de expressieve aktiviteiten van psychiatrisch verpleegkundigen. De overeenkomst met het agogische aspekt van Van Bergen \& Hollands (1978) is hierbij zonder meer duidelijk. In het onderzoek zal deze faktor aangeduid worden als begeleidingsgerichtheid. 
De derde faktor bestaat uit de oorspronkelijk (gewogen) informatie \& koördinatieschaal. Een vergelijking met de koördinatie van zorg, zoals uitgewerkt in het eerder aangehaalde meetinstrument, betreft daarvan uitsluitend de dimensie overleg, waarbij dit betrekking heeft op overleg met andere disciplines en met familie van de patiënt (Van Bergen, e.a., 1980). In het onderzoek zal deze faktor derhalve aangeduid worden als overleggerichtheild.

De taakopvattingen van psychiatrisch verpleegkundigen zijn teruggebracht tot drie faktoren: zorg- begeleidings- en overleggerichtheid. Uiteraard is dit onderscheid in drie typen taken overwegend wan theoretische aard, aangezien in werkelijkheid deze taken onlosmakelijk met elkaar verbonden zijn.

\subsection{Taakopvattingen naar persoonskenmerken}

De persoonskenmerken gelden als mogelijke determinanten van taakopvattingen. Bij de bestudering daarvan is een beperking aangebracht tot de funktie, het geslacht, ervaring en opleiding inrichtingswerk (zie hfdst. 3).

\section{Funktie}

Verondersteld wordt dat taakopvattingen verschillen tussen leidinggevenden en nietleidinggevenden. Uit de analyses blijkt inderdaad dat, bij een onderscheid naar vier hiërarchisch oplopende funktiegroepen, er sprake is van verbanden tussen het funktieniveau en de taken (zie Tabel 5.13.).

Tabel 5.13. Gemiddelde taakopvattingen naar funktie (1988)

\begin{tabular}{lcccc}
\hline & begeleid. $\left.{ }^{*}\right)$ & zorg.**) & overleg ${ }^{* * *}$ ) & $\mathrm{n}$ \\
\hline teamlid & .75 & .09 & -.19 & 523 \\
waarnemend hoofd & .12 & .10 & .23 & 52 \\
afdelingshoofd & -.34 & -.42 & .71 & 93 \\
koörd. afd. hoofd & -.41 & -.82 & 1.26 & 20 \\
\hline
\end{tabular}

*) $\left.\left.F=5.72 p<0.0011^{* *}\right) F=12.00 p<0.001^{* * *}\right) F=37.20 p<0.001$

Uit een recent onderzoek naar het beroep van psychiatrisch verpleegkundige is gebleken dat, ongeacht funktie, iedereen alles doet (Borgesius, e.a. 1988). Daarbij geldt evenwel een belangrijke nuancering, zo blijkt uit Tabel 5.13: iedereen doet alles, maar niet in gelijke mate!

Een veel gehoorde opmerking aan het adres van de verpleging in het algemeen is 
dat verpleegkundigen minder betrokken zijn bij de patiëntenzorg naarmate zij een hogere funktie bekleden. Ook deze wordt bevestigd door de onderzoeksresultaten. Doch ook hier is een nuancering met betrekking tot de psychiatrische verpleging op zijn plaats. Alle psychiatrisch verpleegkundigen, variërend van teamlid tot afdelingshoofd, zijn betrokken bij, dus hebben direkt kontakt met, patiënten.

\section{Ervaring}

Leidinggevenden hebben in het algemeen ook langduriger werkervaring dan niet leidinggevenden. In hoofdstuk werd reeds vermeld dat er een verband $(r=0.53)$ bestaat tussen funktie en jaren werkervaring. Dit verband is evenwel niet van dien aard dat aangenomen mag worden dat funktie en jaren ervaring precies hetzelfde meten. Toch blijkt ervaring in zekere zin hetzelfde patroon voor de takopvattingen weer te geven als funktie. Naarmate men langduriger ervaring heeft wordt namelijk minder aan begeleidingsgerichte en zorggerichte aktiviteiten gedaan, doch meer aan overleggerichte taken (zie Tabel 5.14.)

Tabel 5.14. Gemiddelde taakopvatting naar jaren ervaring

\begin{tabular}{lllll}
\hline jaren ervaring & \multicolumn{1}{c}{ begeleid.* } & zorg.**) & overleg.***) & n \\
\hline tot 5 jaar & .14 & .16 & -11 & 254 \\
5 tot 15 jaar & .01 & .12 & -.01 & 348 \\
15 jaar + & .41 & -.62 & .45 & 87 \\
\hline
\end{tabular}

*) $\left.\left.\mathrm{F}=9.41 \mathrm{p}<0.001^{* *}\right) \mathrm{F}=9.89 \mathrm{p}<0.001^{* * *}\right) \mathrm{F}=19.21 \mathrm{p}<0.001$

\section{Geslacht}

Onder andere vanwege de huishoudelijke en verzorgende aktiviteiten wordt de verpleging overwegend gezien als een vrouwenberoep (Bischoff, 1982). De psychiatrische verpleging bevestigt in feite dit beeld niet, aangezien daarin nagenoeg evenveel mannen als vrouwen werkzaam zijn. In de verdeling naar funkties worden de 'klassieke rolpatronen' wel bevestigd: mannen zijn relatief oververtegenwoordigd op leidinggevende funkties. Tijdens de oriëntatiefase van dit onderzoek werd aangetoond dat vrouwen oververtegenwoordigd zijn op de afdelingen waar meer sprake is van verzorgende werkzaamheden: de geriatrische afdelingen (Dassen e.a., 1987/88). De verdeling van het werk tussen mannen en vrouwen lijkt daardoor ook in de psychiatrische verpleging volgens traditionele rolpatronen sekse-specifiek te zijn.

De begeleidingsgerichte aktiviteiten verschillen niet tussen mannen en vrouwen. De overige aktiviteiten verschillen wel. Vrouwen doen meer zorggerichte aktiviteiten 
(gem. m. -0.13 , vr. $0.11 ; \mathrm{t}=3.04, \mathrm{p}<0.01$ ), en minder overleggerichte aktiviteiten (gem. m. 0.21 , vr. $-0.19 ; \mathfrak{t}=5.06, p<0.001)$.

Dit wijst op een bevestiging van het hiervoor gestelde beeld, dat vrouwen meer zorggerichte aktiviteiten zouden doen. Konklusies kunnen hier evenwel nog niet aan verbonden worden, aangezien de verschillen gekontroleerd dienen te worden voor funktie, ervaring en sektor. In hoofdstuk zeven zal daar nader op ingegaan worden.

\section{Opleiding inrichtingswerk}

Verwacht werd dat verpleegkundigen/inrichtingswerkers meer gericht zouden zijn op agogisch-begeleidende taken dan verpleegkundigen die geen diploma inrichtingswerk bezitten.

Verschillen tussen verpleegkundigen, die een opleiding inrichtingswerk gevolgd hebben, en kollega's zonder zo'n opleiding zijn er inderdaad voor de begeleidingsgerichte aktiviteiten. Verpleegkundigen met een diploma inrichtingswerk geven aan die aktiviteiten vaker te doen (gem. verpl. $-0.03, v+i . w .0 .25 ; t=2.17, p<0.05$ ). Voor de overige taken zijn er geen verschillen tussen beide groepen aantoonbaar in het onderzoek.

\subsection{Taakopvattingen naar sektor en instelling}

\section{Sektor}

Gezien de verschillen in de aard van de zorgverlening tussen de longstay en de shortstay-afdelingen wordt verwacht dat men met name in de longstay meer op zorg en in de shortstay meer op begeleiding gericht zal zijn. De analyses bevestigen deze verwachting. In de longstay afdelingen ligt de nadruk meer op zorggerichte aktiviteiten. In de shortstay ligt de nadruk meer op begeleidingsgerichte en overleggerichte aktiviteiten (zie Tabel 5.15.).

Tabel 5.15. Gemiddelde taakopvatting naar sektor

\begin{tabular}{lccc}
\hline & begeleid. & zorg. & overleg \\
\hline longstay & -0.28 & 0.21 & -0.17 \\
shortstay & 0.10 & -0.20 & 0.20 \\
\hline signifikant: $t=(p<0.001)$ & 7.11 & 5.20 & 4.84
\end{tabular}




\section{Psychiatrische centra}

Hoewel in alle aan het onderzoek deelnemende psychiatrische centra dezelfde kategorieën patiënten verpleegd worden, wil dit niet zonder meer zeggen dat men ook overal in gelijke mate gericht is op zorg, danwel begeleidende aktiviteiten. Dit blijkt althans uit een vergelijking van de taakopvattingen tussen de instellingen (zie Tabel 5.16.).

Tabel 5.16. Gemiddelde taakopvattingen naar instellingen

\begin{tabular}{|c|c|c|c|}
\hline instelling & zorg. & begeleid. & overleg \\
\hline A & -.21 & -.07 & .09 \\
\hline B & .35 & .01 & .16 \\
\hline C & .04 & -.34 & -.17 \\
\hline $\mathrm{D}$ & .08 & -.12 & .11 \\
\hline$E$ & -.13 & .33 & .10 \\
\hline$F$ & -.14 & .15 & -.30 \\
\hline $\begin{array}{l}\text { signifikant } t= \\
\text { *) } p<0.001\end{array}$ & $\begin{array}{l}\left.5.11^{*}\right) \\
.01\end{array}$ & $\left.5.78^{*}\right)$ & $3.60 * * 2)$ \\
\hline
\end{tabular}

Alle drie de taakopvattingen verschillen signifikant tussen de instellingen onderling. In instelling B, is men het meest zorggericht, doch niet het minst begeleidingsgericht. Het minst zorggericht zijn verpleegkundigen in instelling A Begeleidingsgericht is men het meeste in instelling $\mathrm{E}$ In instelling $\mathrm{F}$ is er het minst, en in instelling $\mathrm{B}$ het meest sprake van overleggerichtheid.

Een hoge zorggerichtheid hangt dus niet per definitie samen met een lage begeleidingsgerichtheid van verpleegkundigen.

\section{Konklusie}

De wenselijkheid ten aanzien van de taken van psychiatrisch verpleegkundigen laat een tendens zien zie overeenkomt met de anti-hospitalisatiegedachte, die ervan uitgaat dat verpleegkundigen zich minder dienen te richten op persoonlijke zorg en meer op begeleiding. Ook de relatieve voldoening van de aktiviteiten komt overeen met dit patroon: de agogische aktiviteiten geven de meeste voldoening; de persoonlijke zorg en de begeleiding bij het huishouden geven de minste voldoening.

Door de aanwezigheid van een antwoordtendentie is de konstruktie van de schalen om de aktiviteiten te meten beperkt. Alleen de (ervaren) feitelijkheid is geschikt voor de analyses van het onderzoek. Daarvoor is dan wel een kombinatie gemaakt 
van de relatieve tijdsbesteding en de frekwentie waarin de aktiviteiten verricht worden. Deze gewogen taakopvatting is uiteindelijk gereduceerd tot drie dimensies van de taken, die korresponderen met in de literatuur beschreven aspekten van de taken van verpleegkundigen.

De mate waarin de aktiviteiten verricht worden verschilt zowel naar funktie, ervaringsjaren, geslacht en het al dan niet bezitten van een diploma inrichtingswerk. Ook zijn er verschillen tussen de verpleegkundigen die op longstay-afdelingen werken en verpleegkundigen die op shortstay-afdelingen werken. Alle taken verschillen eveneens tussen de zes aan het onderzoek deelnemende psychiatrische centra.

Aangezien de taken alleen bivariaat getoetst zijn is het niet mogelijk om uit de verschillen tussen de achtergrondkenmerken konklusies te trekken. Daartoe is een multivariate toetsing noodzakelijk. Deze zal in hoofdstuk 7 behandeld worden. 


\section{CHRONICITEIT, IDENTIFIKATIE EN BURNOUT}

\section{Inleiding}

In dit hoofdstuk staan de begrippen 'chroniciteit" 'identifikatie' en 'burnout" centraal, waarbij respektievelijk aan de orde zal komen hoe deze begrippen gemeten zijn, wat de samenhang ervan met de persoonskenmerken is, alsmede wat de verbanden zijn met de sektoren en de psychiatrische instellingen.

\subsection{Visie op chroniciteit}

\section{Konstruktie van de Chroniciteit These Schaal (C.T.S.)}

In hoofdstuk 1 is vermeld dat aan de visie op chroniciteit drie benaderingen te onderscheiden zijn: de hospitalisatiethese; de ziektethese en de handicapthese. De hospitalisatiethese en de ziektethese vormen daarbij min of meer aan elkaar tegengestelde benaderingen, terwijl de handicapthese juist een integratie van die twee visies probeert te zijn. Aangezien juist de hospitalisatiethese en de ziektethese refereren aan de veranderde opvattingen in de geestelijke gezondheidszorg, is bij het meten van de visie op chroniciteit voor deze twee benaderingen gekozen.

Voor het samenstellen van de meetschaal over chroniciteit is gebruik gemaakt van gegevens uit de interviews. Uitspraken die betrekking hadden op hospitalisatie en ziekte werden daarbij zo letterlijk mogelijk gebruikt voor het opstellen van de items. De gekozen antwoordschaal is een 5 punts Likertschaaltype, lopend van: 'helemaal eens' tot 'helemaal oneens'. De veronderstelde subschalen zijn hospitalisatiethese en ziektethese. Het bestaan van deze twee subschalen werd inderdaad bevestigd door de faktoranalyse. De eerste faktor ziektethese bestaat uit vragen die, hetzij refereren aan het typeren van chronische psychiatrische patiënten als zijnde zieke mensen, hetzij refereren aan medische begrippen. Uit Tabel 6.1. blijkt dat het merendeel van de respondenten het vrijwel geheel eens is met de ziektethese als verklaring voor chroniciteit.

De tweede faktor hospitalisatiethese bestaat uit vragen die refereren aan de institutionalisering als veroorzaker -van het 'chronisch' worden van psychiatrische patiënten. Vooral over de antwoorden op de vragen die betrekking hebben op deze these verschillen verpleegkundigen van mening (zie Tabel 6.1.).

In de literatuur (zie o.a. Ciompi, 1980) worden beide opvattingen, hospitalisatie- en ziektethese wel als elkaars tegengestelde beschouwd. De negatieve samenhang tussen de faktoren is daarvan een bevestiging. De sterkte van het verband $(r=-0.24)$ geeft aan dat het geen volledig wederzijds uitsluitende opvattingen zijn. In feite gaat het 
Tabel 6.1. Frekwenties C.T.S. in procenten, en faktorladingen

(varimax rotatie)

\begin{tabular}{|c|c|c|c|c|c|c|}
\hline & & eens & $\mathrm{g} / \mathrm{m}$ & oneens & fakto & rlading \\
\hline & rese & & & & & \\
\hline 1. & $\begin{array}{l}\text { chron patienten worden be- } \\
\text { Lemmerd door zilekte }\end{array}$ & 86 & 4 & 10 & .75 & .05 \\
\hline 2. & chron. patiènten zijn & & & & & \\
\hline & zieke mensen & 80 & 6 & 13 & .77 & -.09 \\
\hline 3. & hun ziektebeeld is niet & & & & & \\
\hline 4. & $\begin{array}{l}\text { Inpaspalar in eem gezlin } \\
\text { ze zijn dusdanig ziek dat }\end{array}$ & 60 & 14 & 19 & .60 & -.18 \\
\hline 5. & $\begin{array}{l}\text { ze niet in maatsch. funkt. } \\
\text { de meesten wertonen duide- }\end{array}$ & 60 & 13 & 27 & .62 & -.24 \\
\hline & lijk psychiatrisch gedrag & 78 & 4 & 17 & 58 & -.06 \\
\hline 6. & $\begin{array}{l}\text { het zijn vooral (chronisch-) } \\
\text { psychotische mensen }\end{array}$ & 38 & 11 & 51 & .54 & .11 \\
\hline & alisatiethese & & & & & \\
\hline 1. & $\begin{array}{l}\text { hun gedrag heeft wooral te } \\
\text { maken met langdurige opname }\end{array}$ & 44 & 15 & 41 & .08 & .76 \\
\hline 2. & hospitalisatie-effekten zijn & & & & & \\
\hline 3. & $\begin{array}{l}\text { oorzaak van verblijf in p.i. } \\
\text { niet ziekte, maar de psychia- }\end{array}$ & 48 & 13 & 39 & -.05 & .74 \\
\hline 4. & $\begin{array}{l}\text { trie is schuld aan hun gedrag } \\
\text { ze zijn verlleerd om eigen ini- }\end{array}$ & 14 & 18 & 68 & -.24 & .70 \\
\hline & tiatieven te nemen & 68 & 10 & 22 & .16 & .66 \\
\hline 3. & $\begin{array}{l}\text { het zijn gewone mensen die } \\
\text { gehospitaliseerd zijn geraakt }\end{array}$ & 11 & 7 & 83 & .23 & .60 \\
\hline & arde & & & & $\begin{array}{l}3.2 \\
29 \%\end{array}$ & $\begin{array}{l}1.9 \\
18 \%\end{array}$ \\
\hline
\end{tabular}

Tabel 6.2. Schaalwaarden C.T.S. $\left.{ }^{*}\right)(1988 ; \mathrm{n}=697)$

\begin{tabular}{llllll}
\hline & alfa & gem. & s.d. & $\min / \max$ & items \\
\hline ziektethese & 0.72 & 21.3 & 3.6 & $6-30$ & 6 \\
hospitalisatiethese & 0.73 & 14.2 & 3.3 & $5-25$ & 5 \\
\hline
\end{tabular}

*) somskores 
om verschillende gezichtspunten die gerelateerd zijn aan een medische danwel een meer psycho-sociale benadering.

\section{Betrouwbaarheid C.T.S.}

De interne konsistentie van de ziektethese-schaal is 0.72 ; voor de hospitalisatiethese-schaal is dit 0.73 . Hieruit wordt gekonkludeerd dat er sprake is van voldoende homogene subschalen (zie Tabel 6.2.).

\section{C.T.S. naar persoonskenmerken}

Zowel funktie als het aantal jaren dat men werkzaam is en het feit of men al dan niet een opleiding inrichtingswerk gevolgd heeft, vertoont samenhang met opvattingen over de chroniciteit-thesen.

Teamleden zijn het meeste van mening dat chroniciteit gezien moet worden als een gevolg van de institutionalisering (zie Tabel 6.3). Koördinerende afdelingshoofden vinden dit het minst. Wat de ziektethese betreft zijn er geen signifikante verschillen tussen verpleegkundigen die in verschillende funkties werkzaam zijn.

Tabel 6.3.

C.T.S uitgesplitst naar funktie

\begin{tabular}{|c|c|c|c|c|c|}
\hline & \multicolumn{2}{|c|}{ ziektethese } & \multicolumn{2}{|c|}{ hospitalisatiethese *) } & $\mathrm{n}$ \\
\hline teamlid & 21.3 & (3.6) & 14.3 & (3.3) & 523 \\
\hline waarnemend hoofd & 21.3 & (3.6) & 13.6 & $(3.0)$ & 52 \\
\hline afdelingshoofd & 21.8 & (3.3) & 13.8 & (3.6) & 93 \\
\hline koörd. afdelingshoofd & 21.3 & $(2.9)$ & 12.5 & (3.4) & 20 \\
\hline totaal & 21.3 & (3.7) & 14.2 & (3.3) & 688 \\
\hline
\end{tabular}

*) $F=2.91 p<0.05$

Voor ervaring geldt een tegengestelde beeld, dat wil zeggen dat de ziektethese wel signifikante verschillen tussen de drie groepen vertoont, maar de hospitalisatiethese niet (Tabel 6.4.).

Verpleegkundigen die een opleiding inrichtingswerk gevolgd hebben zijn gemiddeld meer van mening dat chroniciteit gezien moet worden als een hospitalisatie-artefakt dan hun kollega's zonder zo'n opleiding (resp.: 15.0 en 13.9; $\mathrm{t}=2.46 \mathrm{p}<0.05$ ). Dit is conform de verwachting, aangezien de opleiding inrichtingswerk een sociaal-agogi- 
sche opleiding is, terwijl de verpleegkunde opleidingen sterk aanleunen tegen de medische benadering van ziekte. Het verschil in opvatting komt eveneens tot uitdrukking in de skores op de ziektethese-schaal. Verpleegkundigen met een diploma inrichtingswerk vinden minder dat chroniciteit gezien moet worden als gevolg van ziekte (resp.: 21.4 en $20.4 ; t=2.28$, $\mathrm{p}<0.05$ ).

Tabel 6.4.

C.T.S. uitgesplitst naar jaren ervaring

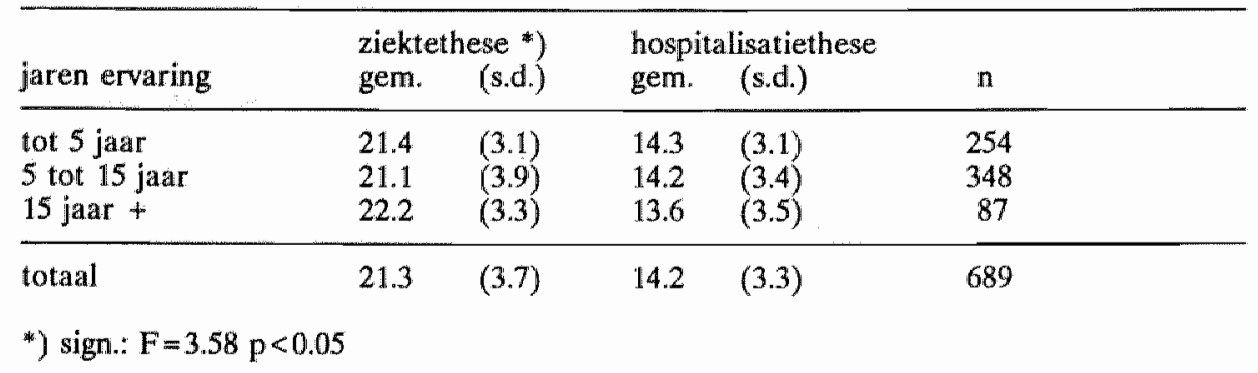

\section{C.T.S. naar sektor en instelling}

Over de hospitalisatiethese verschillen de verpleegkundigen in de longstay en de shortstay niet van mening. Dat geldt echter wel voor de ziektethese. Verpleegkundigen die in de shortstay-sektor werkzaam zijn vinden gemiddeld iets minder dat chroniciteit beschouwd moet worden als gevolg van ziekte, dan hun kollega's uit de longstay-sektor (gem. shst. 21.0, 1st. 21.6; $\mathrm{t}=2.13, \mathrm{p}<0.05$ ).

Ook tussen verpleegkundigen van de deelnemende instellingen is er verschil van mening over chroniciteit. Zowel voor de skores op de ziektethese-schaal als voor de skores op de hospitalisatiethese-schaal zijn er signifikante verschillen tussen de verpleegkundigen uit verschillende instellingen (zie Tabel 6.5).

Bij de hospitalisatiethese valt vooral de relatief lage skore van instelling D op. De verpleegkundigen uit die instelling maken deel uit van diegenen die het meest van mening zijn dat chroniciteit een gevolg is van ziekte, zij zijn eveneens het minst van mening dat chroniciteit een gevolg is van institutionalisering. 


\begin{tabular}{|c|c|c|c|c|}
\hline & \multicolumn{2}{|c|}{ ziektethese } & \multicolumn{2}{|c|}{$\begin{array}{l}\text { hospitalisatiethese. } \\
\text { gen. (s.d.) }\end{array}$} \\
\hline A & 21.6 & $(3,4)$ & 14.4 & (3.3) \\
\hline B & 21.1 & $(3.7)$ & 14.6 & $(3.4)$ \\
\hline $\mathrm{C}$ & 22.2 & $(3,0)$ & 14.0 & $(3.2)$ \\
\hline $\mathrm{D}$ & 22.3 & $(3.4)$ & 12.9 & $(3.0)$ \\
\hline$E$ & 20.5 & $(3.8)$ & 14.1 & $(3.5)$ \\
\hline$F$ & 20.5 & $(3.5)$ & 14.6 & $(3.3)$ \\
\hline totaal & 21.1 & $(3.7)$ & 14.3 & $(3,3)$ \\
\hline
\end{tabular}

\subsection{Beroepsidentifikatie}

\section{Konstruktie van de Verpleegkundige Identifikatie Schaal (V.I.S.)}

Uit de interviews bleek dat de beroepsidentifikatie niet eenduidig is. Zoals in hoofdstuk 1 besproken is spitst de diskussie rond de beroepsidentiteit van psychiatrisch verpleegkundigen zich toe op de vraag of zij primair verpleegkundige zijn danwel therapeut. Bij de meting van de identifikatie wordt derhalve uitgegaan van twee benaderingen namelijk identifikatie met verplegen en identifikatie met therapeuten. Ook de identifikatie schaal werd samengesteld aan de hand van uitspraken uilt de interviews. Het bestaan van de veronderstelde faktoren wordt inderdaad bevestigd met faktoranalyse. Alvorens deze nader te bespreken zal eerst aandacht besteed worden aan enkele antwoorden die men gaf op de uitspraken. Deze zijn in Tabel 6.6. opgenomen. Enkele uitspraken werden vanwege scheefheid van de verdeling van de antwoorden niet opgenomen of makkten geen deel uit van de bedoelde faktoren. Ze zijn echter zeer de moeite waard om hier weer te geven. Vandaar dat aan de tabel. ook een restgroep toegevoegd is. Gezien de diskussie over verplegen als een ondeelbaar beroep (zie hfdst. 1), zijn vooral de antwoorden op de vragen naar de overeenkomst met de ziekenhuisverpleging en de zwakzinnigenzorg van belang.

Ruim een kwart (27\%) van de respondenten is van mening dat hun werk veel overeenkomst met het werk van een $\mathrm{A}$-verpleegkundige heeft; $64 \%$ van de deelnemers aan de enquête is het daar niet mee eens. Ook de overeenkomst van de 'B-verpleging' met de 'Z-verpleging' wordt door de helft (50\%) van de respondenten verworpen. Meer dan een derde (37\%) vindt evenwel dat de 'B-verpleging' en de 'Z-verpleging' veel overeenkomst hebben. De mening over de overeenkomst met de A-verpleging verschilt niet tussen verpleegkundigen in de longstay en de shortstay. 


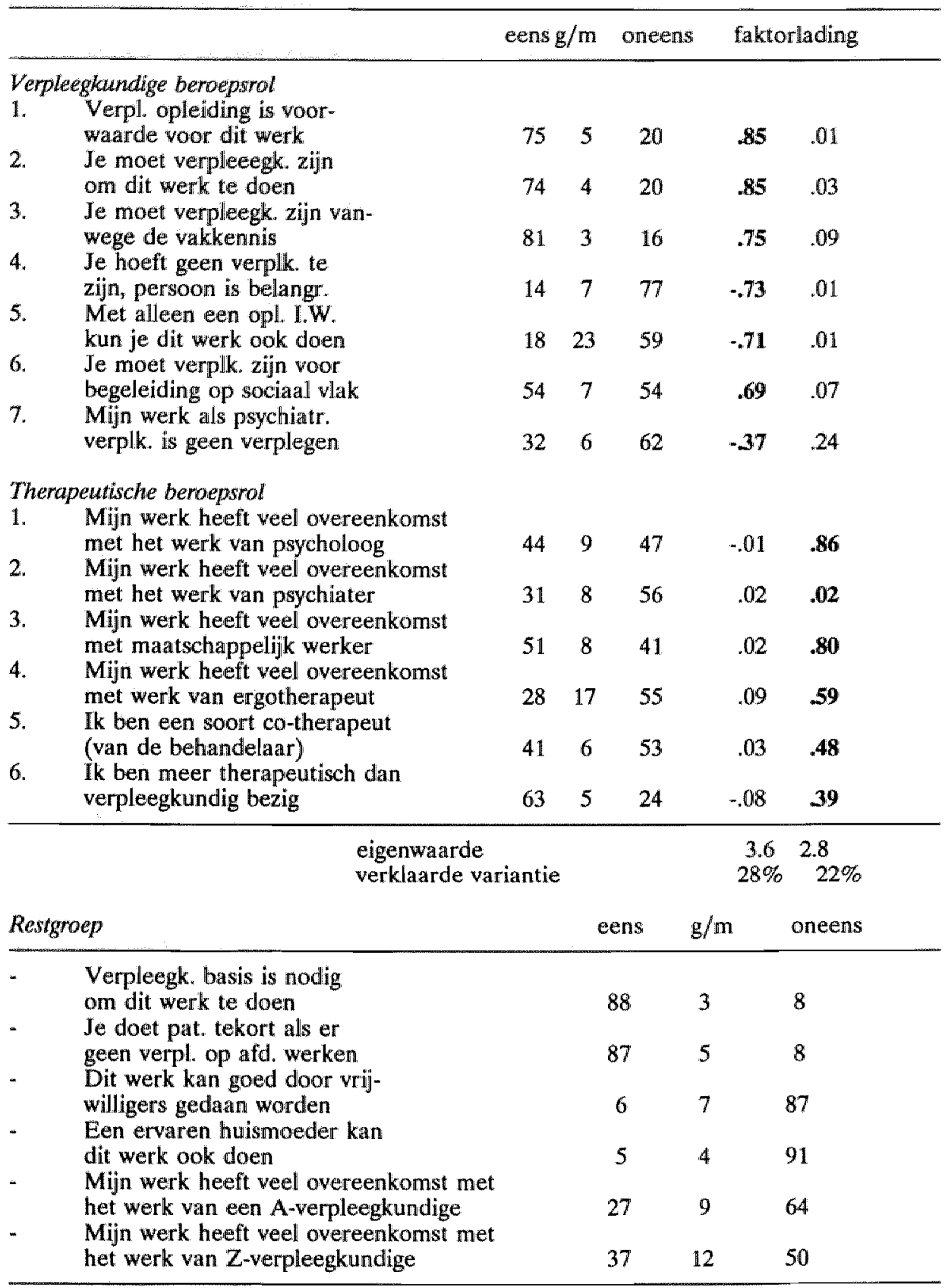


De mening over de gelijkenis met de Z-verpleging verschilt wel tussen verpleegkundigen in de shortstay en de longstay $\left(\mathrm{ch}^{2}=36.6 \mathrm{p}<0.01\right)$. Van de respondenten uit de longstay is $46 \%$ het eens en $40 \%$ oneens met de overeenkomst tussen $\mathrm{Z}$. verpleging en B-verpleging. Van de respondenten uit de shortstay is $29 \%$ het hiermee eens en $61 \%$ het oneens.

Tijdens de verkenning door middel van interviews werd door ongeveer de helft van de geïnterviewden gesteld dat het niet echt nodig was om verpleegkundige te zijn voor hun werk: het begeleiden van chronische patiënten (zie hfdst. 2). De gegevens uit de enquête laten een geheel ander beeld zien. Slechts 5\% van de respondenten vindt dat een 'ervaren huismoeder' hun werk ook zou kunnen doen. Een nagenoeg even klein aantal (6\%) respondenten vindt dat het werk goed door vrijwilligers gedaan kan worden. De overgrote meerderheid $(87 \%)$ van de respondenten vindt dat men patiënten tekort doet, als geen verpleegkundigen op de afdelingen werken.

Een ongeveer even grote groep ( $88 \%$ ) is van mening dat een verpleegkundige basis nodig is, vanwege de vakkennis. Dit komt overeen met het antwoord op de eerste zeven vragen van Tabel 6.6., waaruit blijkt dat zo'n drie kwart van de respondenten vindt dat je verpleegkundige moet zijn, of een verpleegkundige opleiding gevolgd moet hebben, om het werk te doen.

Resumerend betekent dit dat psychiatrisch verpleegkundigen van mening zijn dat zij een beroep uitoefenen, dat zich onderscheidt van het werken als verpleegkundige in algemene ziekenhuizen en zwakzinnigeninstellingen en dat niet door ongekwalificeerd personeel uitgeaefend kan worden. Men ziet psychiatrisch verplegen als een vak, waarvoor bepaalde vakkennis van belang is.

\section{Samenstelling subschalen: identifikatie verplegen/therapeuten}

Zoals reeds gesteld, werden met behulp van faktoranalyse twee subschalen samengesteld. Deze faktoren betreffen de identifikatie met verplegen en de identifikatie met therapeuten. (resp. vraag $1-7$ en vraag $8-13$ uit Tabel 6.6).

De op basis van de faktoren door middel van somskores samengestelde schalen vertonen geen samenhang $(r=0.01)$; hetgeen betekent dat identifikatie met verplegen niets zegt over identifikatie met therapeuten. De interne konsistentie van de schalen is voldoende, zoals blijkt uit Tabel 6.7. 
Tabel 6.7. Schaalwaarden V.I.S**)

\begin{tabular}{lccccc}
\hline & alfa & gem. & s.d. & min-max & items \\
\hline identifikatie verpllegen & 0.82 & 25.5 & 5.3 & $7-35$ & 7 \\
identifikatie therapeut & 0.76 & 17.3 & 5.0 & $6-30$ & 6 \\
\hline
\end{tabular}

) sornskores

\section{V.I.S. now persoonskenmerken}

De skores op de identifikatieschalen vertonen alleen statistisch signifikante verschillen met funktie en het al dan niet bezitten van een diploma inrichtingswerk. Dit betekent dat er geen verschillen in beroepsidentifikatie zijn tussen mannen en vrouwen, alsmede tussen psychiatrisch verpleegkundigen met veel of weinig ervaringsjaren.

\section{Funktie}

Hoewel er geen verschil in beroepsidentifikatie is naar ervaring, wordt wel een verschil aangetoond tussen funktionarissen die in verschillende posities werkzaam zijn. De identifikatie met verplegen is het laagste bij teamleden en het hoogste bij koördinerende afdelingshoofden (zie Tabel 6.8.). Dit is opmerkelijk omdat afdelingshoofden het minst daadwerkelijk verplegen. Wellïht denken zij wel het meeste in termen van professionalisering.

Tabel 6.8. V.I.S. uitgesplitst naar funktie

\begin{tabular}{lllll}
\hline & \multicolumn{2}{l}{ ident. verpl ${ }^{*}$ ) } & \multicolumn{2}{l}{ ident. therap. } \\
& gem. & (s.d.) & gem. & (s.d) \\
\hline teamlid & 25.1 & $(5.3)$ & 17.2 & $(4.8)$ \\
waarnemend hoofd & 27.1 & $(5.1)$ & 17.7 & $(5.2)$ \\
afdelingshoofd & 26.9 & $(5.3)$ & 16.6 & $(5.3)$ \\
koord. afdelingshoofd & 27.8 & $(5.8)$ & 18.7 & $(4.4)$ \\
\hline totaal & 25.4 & $(5.2)$ & 17.4 & $(5.0)$
\end{tabular}

*) sign: $F=5.98 \mathrm{p}<0.001$ 


\section{Opleiding inrichtingswerk}

De opleiding inrichtingswerk is een sociaal agogische opleiding die gevolgd kon worden aan sociale akademies. In die zin mag verwacht worden dat het volgen van zo'n opleiding door verpleegkundigen hen dichter bij de therapeuten brengt dan alleen een verpleegkunde opleiding.

Verpleegkundigen die een opleiding inrichtingswerk gevolgd hebben identificeren zich gemiddeld evenwel niet meer of minder met therapeuten dan verpleegkundigen zonder zo'n opleiding. Wel is de identifikatie met verplegen gemiddeld onder verpleegkundigen/inrichtingswerkers lager dan onder verpleegkundigen die geen diploma inrichtingswerk bezitten (resp.: 36.6 en $39.4 ; t=2.50 \mathrm{p}<0.01$ ), dan hun kollega's die alleen een verpleegkunde opleiding gevolgd hebben. Dit wijst er op dat het gevolgd hebben van een opleiding inrichtingswerk mogelijk leidt tot een verminderde identifikatie met verplegen, doch niet tot een hogere identifikatie met therapeuten.

\section{V.I.S. naar sektor en instelling}

Volgens Holman (1986) zouden verpleegkundigen in de shortstay eerder neigen naar 'therapeut' zijn, doordat zij hun identiteit ontlenen aan andere disciplines. In de longstay ligt die identifikatie minder voor de hand, aangezien daar minder met andere disciplines samengewerkt wordt.

Dit verschil in beroepsidentifikatie kan in het onderhavige onderzoek niet bevestigd worden. Zowel voor de identifikatie met verplegen, als de identifikatie met therapeuten, blijken geen signifikante verschillen tussen de verpleegkundigen uit de beide sektoren aantoonbaar.

Tussen beide beroepsidentifikaties bestaat geen samenhang. Een hoge identifikatie met verplegen wijst dus niet op een lage identifikatie met therapeuten. Om meer inzicht te verkrijgen in de beroepsidentifikatie zijn daarom vier kategorieën samengesteld, variërend van hoge identifikatie met therapeuten en verplegen tot een lage identifikatie met beide. Voor het bepalen van de grens tussen hoog en laag is uitgegaan van de mediaan (kleiner of gelijk aan de mediaan is laag; groter dan de mediaan is hoog).

In Tabel 6.9. zijn de respondenten per sektor verdeeld over de vier kategorieën.

De respondenten die zich het minst identificeren met beide beroepsrollen zijn relatief oververtegenwoordigd in de longstay. Twee keer een hoge identifikatie is relatief meer aanwezig bij de shortstay. Een hoge identifikatie met de therapeutische beroepsrol en een lage met verplegen is eveneens meer aanwezig in de shortstay. Dit patroon wijst inderdaad in de richting van een hogere identifikatie met therapeuten op de shortstay; signifikant zijn de verschillen echter niet! 
Identifikatie vitgesplitst naat sektor in procenten

\begin{tabular}{llllllll}
\hline $\begin{array}{l}\text { identifikatic verplegen: } \\
\text { identifikatie therapeut: }\end{array}$ & $\begin{array}{l}\text { laag laag hoog hoog } \\
\text { hoog laag hoog }\end{array}$ & $\begin{array}{l}\text { haag } \\
\text { latal }\end{array}$ & n \\
\hline shortstay & 24 & 27 & 21 & 28 & 100 & 320 \\
longstay & 20 & 35 & 17 & 28 & 100 & 323 \\
\hline totaal & 22 & 31 & 19 & 28 & 100 & 643
\end{tabular}

$c^{2}: 5.40$, niet signifikant

Tussen de instellingen zijn wel verschillen in zowel identifikatie met verplegen, als identifikatie met therapeuten (zie Tabel 6.10.).

Aangezien er geen verschillen tussen de sektoren zijn, en slechts gedeeltelijke verschillen voor de persoonskenmerken, wijst dit erop dat verschillen in beroepsidentifikatie eerder gezocht moeten worden in verschillen in de instellingen.

Tabel 6.10. V.I.S. uitgesplitst naar instellingen

\begin{tabular}{lllll}
\hline instelling & $\begin{array}{c}\text { ident. verpl. } \\
\text { gem. }\end{array}$ & $\begin{array}{c}\text { ident. } \\
(\text { s.d.) }\end{array}$ & $\begin{array}{c}\text { therap.**) } \\
\text { gem. }\end{array}$ & (s.d.) \\
\hline A & 24.1 & $(5.7)$ & 17.5 & $(4.7)$ \\
B & 26.9 & $(4.7)$ & 17.6 & $(4.6)$ \\
C & 24.9 & $(5.6)$ & 17.0 & $(5.3)$ \\
D & 25.7 & $(4.7)$ & 16.7 & $(4.8)$ \\
E & 26.0 & $(5.4)$ & 18.3 & $(5.1)$ \\
F & 26.0 & $(5.2)$ & 16.2 & $(4.9)$ \\
\hline totaal & 25.4 & $(5.2)$ & 17.4 & $(5.0)$
\end{tabular}

*) signifikant: $F=4.23 p<0.001{ }^{* *}$ ) signifikant: $F=2.43 p<0.05$

\subsection{Burnout}

Voor het meten van burnout is gebruik gemaakt van de Maslach Burnout Inventory schaal (M.B.I.), die ontwikkeld is door Maslach en Jackson (1981). Dit instrument bestaat uit drie dimensies: emotional exhaustion, personal accomplishment en depersonalization; respektievelijk te vertalen als emotionele uitputting, persoonlijke voldoening en depersonalisatie.

Emotionele uitputting geeft het meeste weer wat met burnout bedoeld is: het gebrek 
aan emotionele energie om adekwaat op problemen van patiënten te reageren. Men vervalt in routine en vermijdt de emotionele betrokkenheid (Keirse, 1987a).

Persoonlijke voldoening is een vrije vertaling van personal accomplishment. De vertaling is niet geheel overeenkomstig het engelstalige begrip. Bedoeld wordt daarmee namelijk de voldoening die men put uit het eigen handelen, doordat men resultaten van het werk ziet of vertrouwen heeft in het eigen handelen ${ }^{1}$ ).

Depersonalisatie is een vorm van cynisme die tot uitdrukking komt in een negatieve visie op de problemen van patiënten. Men wil het liefst niet met de problemen van patiènten opgezadeld worden en reduceert patiënten tot gevallen.

\section{Het meetinstrument}

Het instrument werd vertaald in het Nederlands en vervolgens uitgetest. ${ }^{2}$ ) De antwoordschaal volgens het Hassles Scale type werd daarbij letterlijk overgenomen. Zo'n schaal bestaat uit twee antwoordgroepen waarvan er één betrekking heeft op de frekwentie waarin zich bepaalde gevoelens voordoen, en de andere op de intensiteit daarvan. De eerste schaal loopt via zes stappen van 'enkele malen per jaar' tot 'elke dag'. De tweede is een zevenpuntsschaal lopend van 'erg sterk' tot 'erg zwak'. Per item werd zo twee antwoorden verkregen. Aangezien bij het uittesten bleek dat men moeite had met beide schalen is besloten om gebruik te maken van een vijfpuntsschaal (nooit ... erg vaak) voor de frekwentie, en een vijfpuntsschaal (erg sterk ... erg zwak) voor de intensiteit ${ }^{3}$ ).

\section{Betrouwbaarheid van het instrument}

De betrouwbaarheid van de subschalen komt redelijk overeen met het oorspronkelijke instrument (zie Tabel 6.11.). Alleen de interne konsistentie van de frekwentie meting. van de depersonalisatie-schaal is aan de lage kant.

1) Hoewel persoonlijke voldoening wellicht doet denken aan arbeidssatisfaktic, is dat toch niet hetzelfde. In de literatuur worden verschillende resultaten aangetroffen over onderzoek naar het verband tussen burnout en arbeidssatisfaktie. Maslach en Jackson (1981) wijzen erop dat er geen. verband is tussen beide begrippen.

2) Voor het vertalen van het instrument is toestemming verkregen van de auteurs. Dr. R.Bambang Oetomo was behulpzaam bij de vertaling en de aanpassing van de itens voor het Nederlandse taalgebied.

3) In Bijlage B.4. zijn de items van de schalen opgenomen. 


\begin{tabular}{lllll}
\hline & \multicolumn{2}{c}{ frekwentie } & \multicolumn{2}{c}{ intensiteit } \\
& M.* & $D^{* *}$ & $\left.M^{*}\right)$ & D.*y \\
\hline gehele schall & 0.83 & 0.71 & 0.84 & 0.81 \\
emotionele uitputting & 0.89 & 0.84 & 0.86 & 0.77 \\
persoonlijke voldoening & 0.74 & 0.72 & 0.74 & 0.73 \\
depersonalisatie & 0.77 & 0.58 & 0.72 & 0.67 \\
\hline
\end{tabular}

*) Maslach \& Jackson, 1981 *) Dit onderzoek

Tabel 6.11b. Schaalwaarden M.B.I. (somskores)

\begin{tabular}{lllll}
\hline & \multicolumn{2}{c}{ frekwentie } & \multicolumn{2}{c}{ intensiteit } \\
& gem. & (s.d.) & gem. & (s.d.) \\
\hline emotionele uitputting & 17.8 & $(4.0)$ & 20.3 & $(6.1)$ \\
persoonlijke voldoening & 17.3 & $(3.6)$ & 37.1 & $(3.7)$ \\
depersonalisatie & 12.8 & $(2.8)$ & 13.1 & $(5.4)$ \\
\hline
\end{tabular}

De Pearson korrelaties tussen de frekwentie- en de intensiteitsmetingen zijn voor emotionele uitputting 0.82 ; voor persoonlijke voldoening 0.70 en voor depersonalisatie 0.83 (alle sign. $\mathrm{p}<0.001$ ). Deze korrelaties zijn hoger dan bekend is van het oorspronkelijk instrument waarbij de korrelaties in diwerse onderzoeken varieerden tussen 0.35 tot 0.73 (Maslach en Jackson, 1981). Volgens de ontwerpers blijkt een aparte meting van frekwentie en intensiteit toch van belang, aangezien bepaalde persoons- of omgevingskenmerken soms slechts met één van beide metingen samenhang vertonen. Om de analyses niet onnodig ingewikkeld te maken zal in dit onderzoek slechts van eén meting gebruik gemaakt worden. De onderlinge samenhang tussen de schalen voor intentie en frekwentie laat dat immers toe. Gekozen wordt voor de intensiteitsmeting, aangezien de interne konsistentie daarvan voor depersonalisatie beter is dan bij de frekwentie meting.

Voor het vergelijken van de gegevens met het oorspronkelijke instrument, zal wel gebruik gemaakt worden van frekwentie en intensiteitsmetingen.

Net als bij het oorspronkelijke instrument is er geen hoge korrelatie tussen persoonlijke voldoening en de andere schalen. Dit wijst erop dat persoonlijke voldoening niet gezien dient te worden als komplementair aan emotionele uitputting of depersonalisatie.

Interkorrelaties tussen de subschalen zijn vooral aanwezig tussen emotionele uitputting en depersonalisatie (zie Tabel 6.12.). 
Tabell 6.12. Interkorrelaties subschalen M.B.L.(Pearson)

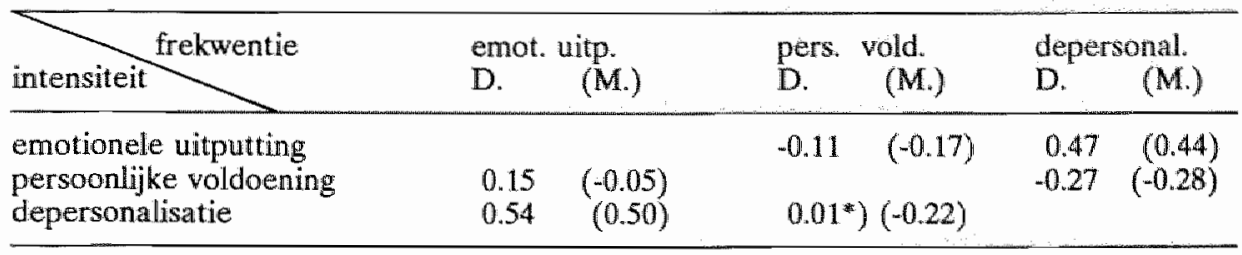

D.: Dit onderzoek M.: Maslach \& Jackson, 1981

* niet signifikant; de overige korrelaties van dit onderzoek zijn signifikant bij $\mathrm{p}<0.01$

De hoge korrelatie tussen emotionele uitputting en depersonalisatie geeft aan dat het om aparte, doch gerelateerde aspekten van burnout gaat; hetgeen overeenkomt met de verwachting van de auteurs van het instrument (Maslach \& Jackson, 1981).

\section{Burnout naar persoonskenmerken}

Voor de intensiteitsmeting van burnout is in dit onderzoek alleen onderscheid gebleken naar geslacht. Verschillen naar funktie en ervaring zijn er niet voor de intensiteit van burnout.

De ontwerpers van de burnoutschaal beschrijwen verschillen tussen mannen en vrouwen voor burnoutskores. Mannen skoren op emotionele uitputting lager, doch op alle andere schalen hoger (Maslach \& Jackson, 1981). Een probleem met het vergelijken van mannen en vrouwen bestond voor de ontwerpers van het instrument daaruit, dat de vergelijking tevens een vergelijking van verschillende beroepsgroepen was ${ }^{4}$ ). Men kon dus niet met zekerheid stellen dat de verschillen inderdaad gerelateerd waren an geslacht.

In een Nederlands onderzoek naar burnout onder leraren werden hogere skores voor mannen op alle schalen aangetroffen. (Van Ginkel, 1987). In dat onderzoek ging het om zowel mannelijke als vrouwelijke leerkrachten, dus mensen die in hetze ffde beroep werkzaam zijn. De bevindingen vam burnout bij psychiatrisch verpleegkundigen komen voor wat betreft geslacht overeen met het onderzoek onder leerkrachten. Mannen skoren gemiddeld op alle schalen hoger dan vrouwen (zie Tabel 6.13).. De verschillen zijn bij persoonlijke voldoening ewenwel niet statistisch signifikant.

4) Het betrof namelijk typische (Amerikaanse) mannen- en vrouwenberoepen zoals de politie en de verpleging. 
Tabel 6.13. Burnout uilgesplitst naar geslacht

\begin{tabular}{llll}
\hline & $\begin{array}{l}\text { emot.uitp. } \\
\text { gem. (s.d.) }\end{array}$ & $\begin{array}{l}\text { pers.vold. } \\
\text { gem. (s.d.) }\end{array}$ & $\begin{array}{l}\text { depersonal. **) } \\
\text { gem. (s.d.) }\end{array}$ \\
\hline mannen & $20.8(5.8)$ & $37.2(3.6)$ & $13.9(5.0)$ \\
vrouwen & $20.0(6.4)$ & $37.1(3.9)$ & $12.6(5.6)$ \\
\hline
\end{tabular}

*)sign.t=1.95 $\left.p<0.05^{*}\right)$ sign. $t=3.36 p<0.01$

\section{Burnout en de sektor}

Burnout, gemeten als emotionele uitputting en verminderde voldoening, is op shortstay-afdelingen hoger dan op longstay-afdelingen. Verpleegkundigen op shortstayafdelingen skoren signifikant hoger op emotionele uitputting $(t=2.09 \quad p<0.05)$ en signifikant lager op persoonlijke voldoening $(t=2.08 \mathrm{p}<0.05)$ dan de kollega's op de longstay-afdelingen.

Als verklaring voor de lagere burnout bij psychiatrisch verpleegkundigen dan bij ziekenhuisverpleegkundigen werd door Dolan (1987) de verklaring gegeven dat dit zou komen door de langere opnameduur van patiënten in psychiatrische instellingen. De bevindingen van dit onderzoek lijken deze verklaring eveneens te bevestigen binnen de psychiatrische verpleging, aangezien de opnameduur in de longstay langer is dan in de shortstay.

\section{Burnout naar instelling}

Tussen de instellingen is er signifikant verschil in de skores op de burnoutschalen voor persoonlijke voldoening en emotionele uitputting (Tabel 6.14.)

Tabel 6.14. Burnout uitgesplitst naar instellingen

\begin{tabular}{llll}
\hline instelling & $\begin{array}{l}\text { emot.uitp.*) } \\
\text { gem. (s.d.) }\end{array}$ & $\begin{array}{l}\text { pers.vold. **) } \\
\text { gem. (s.d.) }\end{array}$ & $\begin{array}{l}\text { depersonal. } \\
\text { gem. (s.d.) }\end{array}$ \\
\hline A & $21.0(6.4)$ & $36.3(4.1)$ & $14.1(5.0)$ \\
B & $20.6(6.3)$ & $38.2(3.2)$ & $13.1(5.1)$ \\
C & $19.1(6.4)$ & $36.6(3.1)$ & $12.7(5.7)$ \\
D & $20.8(5.4)$ & $37.3(3.6)$ & $13.0(5.3)$ \\
E & $21.5(6.0)$ & $38.0(3.4)$ & $13.1(5.6)$ \\
F & $18.1 .(6.4)$ & $36.8(4.1)$ & $12.0(5.6)$ \\
\hline totalal & $20.3(6.1)$ & $37.2(3.6)$ & $13.1 \quad(5.4)$ \\
*) signifikant: F $=4.38 \mathrm{p}<0.001$ & $* *$ ) signifikant: $\mathrm{F}=4.72 \mathrm{p}<0.001$
\end{tabular}


In instelling $F$ is de emotionele uitputting relatief het laagste. De persoonlijke voldoening is daar evenwel niet meer dan gemiddeld. Aangezien in deze instelling de totale respons beduidend lager was dan in de overige psychiatrische centra, zou deze lage skore mogelijk te wijten kunnen zijn aan een selektieve non-respons.

\subsection{Samenhang chroniciteit, identifikatie en burnout}

In hoofdstuk 3 is reeds gewezen op de verbanden tussen de beroepsidentifikatie en de visie op chroniciteit. Beide begrippen staan onder invloed van dezelfde ontwikkeling in de geestelijke gezondheidszorg, namelijk de overgang van overwegend medisch denken naar het sociaal-agogisch denken. Ook de uitwerking van de begrippen past in dit kader van medisch tegenover sociaal: ziektethese versus hospitalisatiethese: identifikatie met verplegen versus identifikatie met therapeuten ${ }^{5}$ ).

De gemeenschappelijke idee achter de beroepsidentifikatie en de visie op chroniciteit veronderstelt een zekere samenhang. Toch wordt die slechts in beperkte mate door het onderzoek bevestigd (zie Tabel 6.15.). Tussen identifikatie met therapeuten. en chroniciteit is geen enkel verband aangetroffen. Wel is er verband tussen identifikatie met verplegen en de chroniciteit these schalen. Naarmate verpleegkundigen zich meer met verplegen identificeren zijn zij meer voorstander van de ziektethese $(r=0.22, p<0.01)$ en minder van de hospitalisatiethese $(r=-0.22, p<0.01)$.

Tabel 6.15. Pearson korrelaties chroniciteit identifikatie en burnout

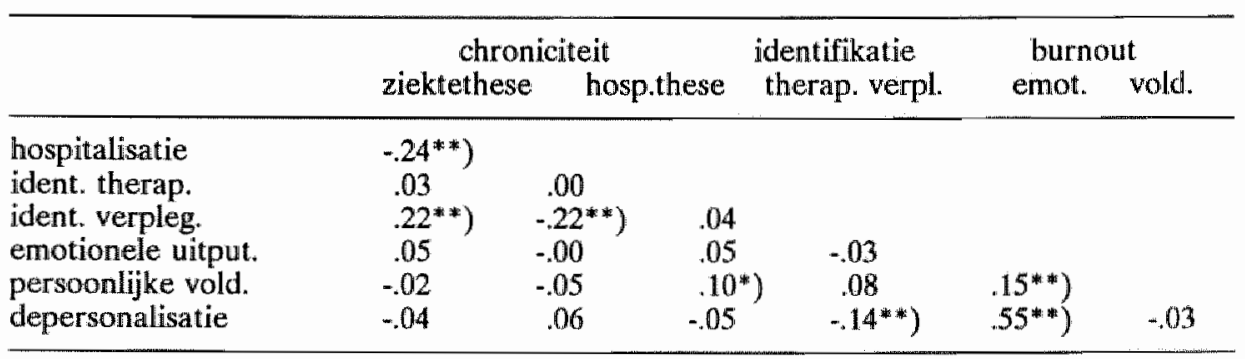

*) $\mathrm{p}<0.01 \quad$ **) $\mathrm{p}<0.001$

5) Voor de goede orde wordt er nogmaals op gewezen dat therapeut hier bedoeld is als begeleider en behandelaar in meer andragogische zin, als onderscheid ten opzichte van medisch therapeutisch behandelaar. 
Burnowt is wan een andere orde dan de hiervoor behandelde begrippen. Tussen burnout en chroniciteit werden dan ook geen verbanden aangetroffen in het onderzoek. Verband tussen burnout en identifikatie blijkt er wel, doch alleen woor depersonalisatie en identifikatie met verplegen $(r=-.14, p<0.01)$. Naarmate men minder gedepersonaliseerd is, is de identifikatie met verplegen groter. Mogelijk wijst dit erop dat de depersonalisatie niet enkel betrekking heeft op de persoon zelf in relatie tot de patiënt, doch ook op de relatie met de direkte omgeving waar deze van deel uitmaakt: de verpleegafdeling.

\section{Samenvatting}

In dit hoofdstuk zijn de centrale onafhankelijke variabelen uitgewerkt. Opvattingen van verpleegkundigen over chroniciteit bestaan uit twee schalen respektievelijk betreffende: de hospitalisatiethese en de ziektethese. Beroepsidentifikatie wordt onderscheiden in identifikatie met verplegen en identifikatie met therapeuten. Burnout omvat emotionele uitputting, persoonlijke voldoening en depersonalisatie. Verpleegkundigen die op longstay-afdelingen werken opteren meer voor de ziektethese, dan hun kollega's uit de shortstay. Verpleegkundigen die een opleiding inrichtingswerk gevolgd hebben opteren meer voor de hospitalisatiethese en minder voor de ziektethese, dan verpleegkundigen zonder een diploma inrichtingswerk. Ook is de identifikatie met verplegen bij de verpleegkundigen/inrichtingswerkers kleiner. In tegenstelling tot wat verwacht werd is er geen verschil in identifikatie met verplegen dan wel met therapeuten tussen verpleegkundigen die in de longstay en de shortstay werkzaam zijn.

Burnout verschilt tussen de sektoren. In de shortstay is de emotionele uitputting hoger en de persoonlijke voldoening lager dan in de longstay.

Tot slot blijkt een verband aantoonbaar tussen chroniciteit en identifikatie. Naarmate verpleegkundigen zich meer met verplegen identificeren opteren zij meer voor de ziektethese en minder voor de hospitalisatiethese.

In het volgende hoofdstuk zal nagegaan worden hoe de hier besproken variabelen samenhangen met de taakopvattingen van psychiatrisch verpleegkundigen. 


\section{VERKLARING VAN VERSCHILLEN IN TAAKOPVATTINGEN}

\section{Inleiding}

De nadruk ligt in dit hoofdstuk op het beantwoorden van de vraag welke kenmerken van psychiatrisch verpleegkundigen de meeste samenhang vertonen met hun takopvattingen. In eerste instantie wordt nagegaan in welke mate taakopvattingen van psychiatrisch verpleegkundigen, conform het onderzoeksmodel, samenhangen met de visie op chroniciteit, de identifikatie met verplegen en burnout. Daarna zal nagegaan worden in welke mate deze en de overige onafhankelijke variabelen gezamenlijk verband houden met de taakopvattingen.

\subsection{Samenhang taakopvattingen met visies over chroniciteit, identifikatie en burnout}

In hoofdstuk 5 zijn de taakopvattingen al in verband gebracht met de sektor, de instellingen en enkele persoonskenmerken. In deze paragraaf wordt nagegaan wat de verbanden tussen de takopvattingen en de in het vorige hoofdstuk behandelde variabelen zijn. In Tabel 7.1 zijn daartoe de Pearson korrelaties weergegeven. Daarbij is tevens onderscheid gemaakt tussen de sektoren longstay en shortstay.

Tabel 7.1. Pearson korrelaties taakopvattingen met visie op chroniciteit, beroepsidentifikatie en burnout

\begin{tabular}{lcllccc}
\hline & \multicolumn{3}{c}{ longstay } & \multicolumn{3}{c}{ shortstay } \\
& zorg & begel. & overleg & zorg & begel. & overleg \\
\hline hospitalisatiethese & .05 & .06 &. .07 & .01 & .08 & .11 \\
ziektethese & .02 & .05 & .08 & .03 & -10 & .03 \\
identifikatie verpl. & .03 & .12 & $\left..27^{* *}\right)$ & .06 & -.10 & -.10 \\
identifikatie ther. & -.08 & $\left..20^{* *}\right)$ & .04 & .00 & .09 & .09 \\
emotionele uitputting & .07 & .04 & .02 & .02 & $\left.-.14^{*}\right)$ & .04 \\
persoonlijke voldoening & .09 & $\left..14^{*}\right)$ & $\left..14^{*}\right)$ & .03 & $\left..20^{* *}\right)$ & .07 \\
depersonalisatie & -.03 &. .09 & .03 & .01 & -.09 & .03 \\
\hline
\end{tabular}

$\left.\left.{ }^{*}\right) \mathrm{p} \leq 0.01 \quad{ }^{* *}\right) \mathrm{p} \leq 0.001$

Het veronderstelde verband tussen de visie op chroniciteit en de taakopvattingen wordt niet aangetroffen. De beroepsidentifikatie hangt wel, doch slechts in beperkte mate, en alleen in de longstay, samen met de taakopvattingen. Zo blijkt er een signifikant verband aantoonbaar tussen identifikatie met verplegen en overleggericht- 
heid $(r=27)$. Dat wil zeggen dat diegenen die zich veel met verplegen identificeren ook veel overleggerichte taken verrichten. Opmerkelijk is hier niet alleen het ontbreken van een signifikant verband in de shortstay, maar ook de tegengestelde richting van de werbanden. In de longstay is er een positief, in de shortstay een negatief verband tussen identifikatie met verplegen en overleggerichtheid.

Voor identifikatie met therapeuten is er, eveneens alleen in de longstay, een positief verband aantoonbaar met begeleidingsgerichtheid $(\mathrm{r}=.20)$ : verpleegkundigen uit de longstay die zich meer met therapeuten identificeren, verrichten meer begeleidingsgerichte aktiviteiten.

Tussen burnout en de taakopvattingen blijken eveneens slechts in beperkte mate verbanden aantoonbaar. Een negatieve korrelatie tussen emotionele uitputting en begeleidingsgerichtheid $(r=-14)$ wordt aangetroffen in de shortstay. Tussen persoonlijke voldoening en begeleiding is zowel in de longstay $(r=.14)$ als in de shortstay $(r=20)$ een signifikant verband aantoonbaar. Alleen in de longstay wordt een verband tussen persoonlijke voldoening en overleggerichtheid aangetroffen $(r=.14)$.

Tussen de takopvattingen en de depersonalisatie worden geen signifikante verbanden aangetroffen.

Hoewel er slechts in geringe mate signifikante verbanden aangetroffen zijn, is uit de wel aantoonbare verbanden op te maken dat de sektor een belangrijke rol speelt. Van de zes signifikante verbanden zijn er vier in de longstay aangetroffen. Het trekken van konklusies daaruit zou evenwel voorbarig zijn. Tot nu toe zijn de verbanden bivariaat van aard. Dat wil zeggen: bij vaststelling van de samenhang tussen een verklarende variabele en een taakopvatting is geen rekening gehouden met de eventuele invloed van de andere verklarende variabelen op het verband. Alvorens definitieve uitspraken te doen is het noodzakelijk een multivariate analyse uit te woeren, waarbij wel rekening wordt gehouden met de onderlinge relaties tussen de verklarende variabelen en de taakopvattingen.

\subsection{Multivariate samenhangen tussen de taakopvattingen en de verklarende variabelen}

Als techniek van multivariate analyse is gekozen voor stapsgewijze multiple regressie, waarbij steeds een van de drie taakopvattingen als afhankelijke variabele fungeert. Het grote aantal respondenten $(n=697)$, alsmede het metrisch karakter van een belangrijk aantal van de variabelen maakt toepassing van regressie-analyse mogelijk. Een speciaal probleem hierbij vormt de variabele instelling. De zes psychiatrische centra samen vormen de nominale, niet-metrische variabele: instelling. Deze is metrisch gemaakt door te werken met zes zogenaamde dummy-variabelen. Zo'n variabele geeft dan aan of een respondent wel of niet in instelling A (resp. B C D E 
F) werkt. Vervolgens worden vijf van deze dummy-variabelen in de regressievergelijking opgenomen. De zesde wordt niet meegenomen, omdat anders statistische ongerijmdheden ontstaan, zoals bijvoorbeeld partiële korrelaties tussen de instellingen wan -1.00 .

Tabel 7.2. geeft een overzicht van de uitkomsten van de regressie-analyses.

Tabel 7.2 .

Multiple regressie analyse taakopvattingen (beta-waarden)

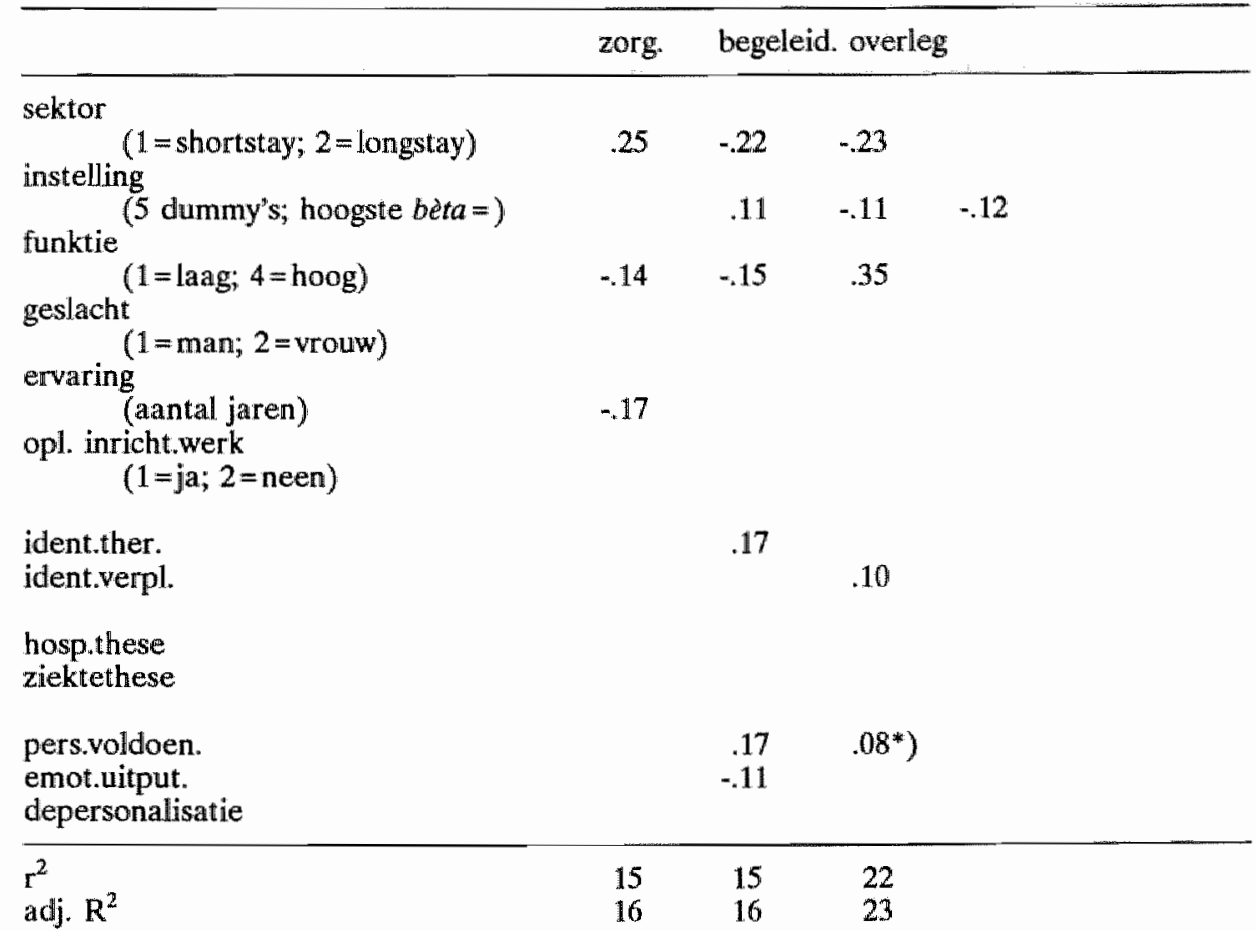

*) signifikant bij $p<0.01$; alle overige bèta's zijn signifikant bij $p<0.001$

De takopvattingen hebben gemeen dat zij alle drie samenhang vertonen met de sektor, met het leidinggevend karakter van de funktie en de instelling waar men werkt. Wie bij chronische patiënten werkzaam is, is vooral gericht op persoonlijke zorg en minder op begeleiding- en overleggerichtheid. Leidinggevenden hebben vooral overleggerichte werkzaamheden en zijn minder direkt betrokken bij de individuele begeleiding en persoonlijke zorg. Voorts blijkt dat elke instelling een uniek effekt heeft op de takkopvattingen. Alle psychiatrische instellingen tonen eén of meer statistisch signifikante verbanden, ook al zijn de regressie-koëfficiënten niet erg hoog. 
Geen enkel effekt geeft geslacht, het al dan niet bezitten van een diploma inrichtingswerk, de visie op chroniciteit en depersonalisatie.

Resumerend kan uit de regressie-analyse het volgende gekonkludeerd worden.

De opvattingen over chroniciteit en het beroep hebben minder samenhang met de taakopvattingen dan werd verwacht. Opvattingen over chroniciteit doen ten aanzien van de taakopvattingen van psychiatrisch verpleegkundigen zelfs in het geheel niet ter zake. Duidelijke verbanden bestaan alleen met de begeleidingsgerichtheid. Die psychiatrisch verpleegkundigen, die in zijn werk sterk de nadruk legt op de individuele begeleiding en de autonomie van de patiënt, voelt zich meer therapeut dan verpleegkundige.

Burnout toont opvallend weinig relatie met de taakopvattingen. In zoverre er verband is wijst dit erop dat diegenen die meer onderhevig zijn aan burnout minder begeleidingsgericht zijn.

Een interessante, maar enigszins losstaande bevinding heeft betrekking op ervaring. Verpleegkundigen met veel dienstjaren besteden, onafhankelijk van het feit of zij al dan niet in een leidinggevende funktie werkzaam zijn, minder tijd aan, zijn althans minder gericht op, persoonlijke verzorging en huishoudelijke taken. Mogelijk houdt dit verband met de werkwerdeling, waarbij vooral de langer gediplomeerden zich minder hoeven te richten op de zorgverlening met betrekking tot de alledaagse aktiviteiten van patiënten.

Het meest opmerkelijk is het verschil in taakopvattingen tussen de instellingen onderling. Dit verschil blijkt ook stand te houden, wanneer het effekt van de sektoren in de analyses betrokken wordt. In de volgende paragraaf zal daarom het verschil in taakopvattingen tussen verpleegkundigen in de deelnemende instellingen uitvoeriger belicht worden.

\subsection{Bespreking van de belangrijkste verklarende variabelen}

In de vorige paragraaf is nagegaan welke van de verklarende variabelen effekt hebben op de taakopvattingen. In deze paragraaf zullen de belangrijkste bevindingen nader toegelicht worden. Daarbij zal vooral aandacht besteed worden aan de onderlinge samenhang tussen de verklarende variabelen.

\section{Sektor, instelling en funktie}

De drie determinanten die het meest samenhangen met de taakopvattingen zijn: sektor, funktie en instelling. In de vorige paragraaf bleek reeds dat verpleegkundigen werkzaam bij chronische patiënten vooral gericht zijn op persoonlijke zorg en minder 
op begeleiding en overleg met derden. Leidinggevenden daarentegen hebben vooral overleggerichte werkzaamheden en zijn minder direkt betrokken bij de individuele begeleiding en de persoonlijk zorg. Wat de instellingen betreft geeft de regressieanalyse wel aan dat er een verband is met bepaalde verpleegkundige taakopvattingen, maar mede door het gebruik van dummy variabelen blijft onduidelijk thoe dit verband er uitziet. Vandaar dat de gemiddelde taakopvattingsskore ten aanzien van op de begeleiding en zorggerichte taken per instelling en sektor in en grafiek weergegeven zijn. Uit die grafiek blijkt dat er tussen de instellingen verschillen zijn in taakopvattingen van psychiatrisch verpleegkundigen (zie Figuur 7.1a/b).
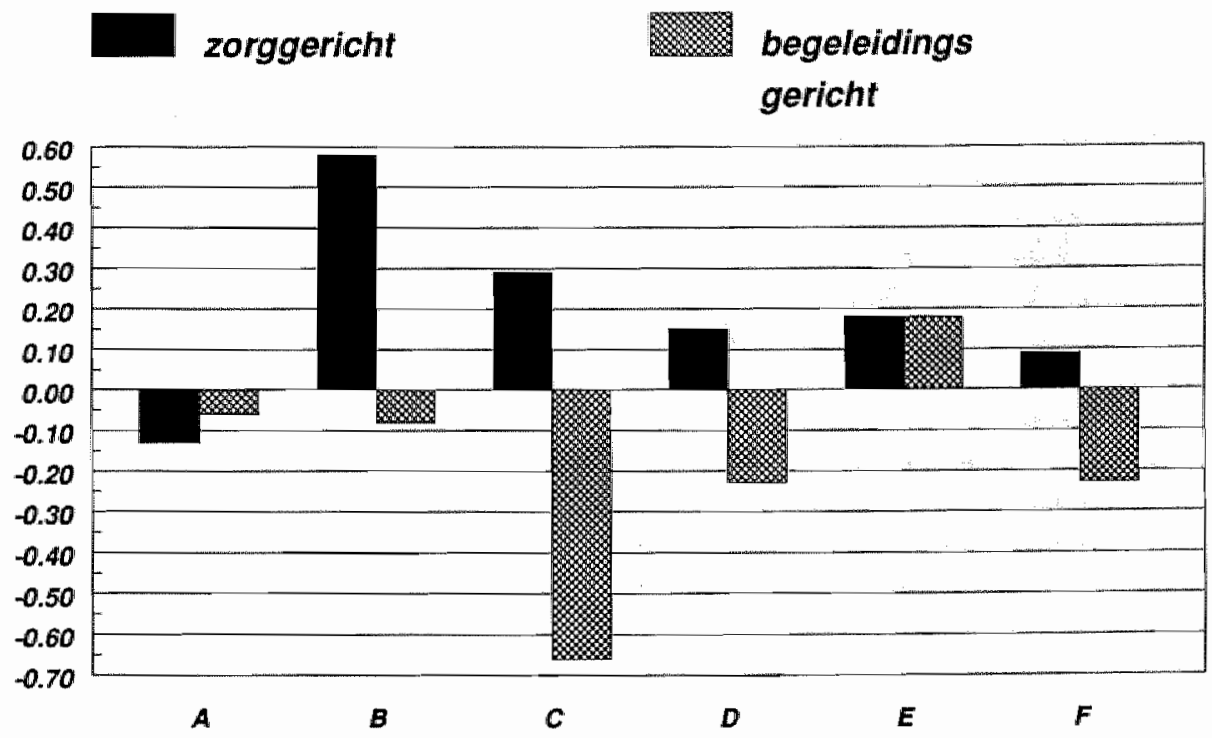

psychiatrische instellingen

Figuur 7.1.a. Zorg en begeleiding in de longstay

In de longstay was het algemene patroon: gemiddeld meer zorg dan begeleidingsgericht zijn. Dit geldt niet voor instelling $A$ en $E$. In $A$ is men in de longstay minder zorggericht dan gemiddeld. In $\mathrm{E}$ is men in de longstay meer begeleidingsgericht, terwijl dit in de andere instellingen juist minder is. Van de zes deelnemende psychiatrische centra is B gemiddeld het meest en A het minst zorggericht in de longstay. 
In de shortstay was algemene patroon tegengesteld aan de longstay, namelijk meer begeleidings- en minder zorggericht. In $\mathrm{A}$ is de begeleidingsgerichtheid er evenwel minder dan gemiddeld. Van de zes instellingen is $C$ het minste zorggericht. In $\mathrm{D}$ is zowel de zorg- als de begeleidingsgerichtheid in de shortstay nagenoeg gelijk aan het totale gemiddelde.

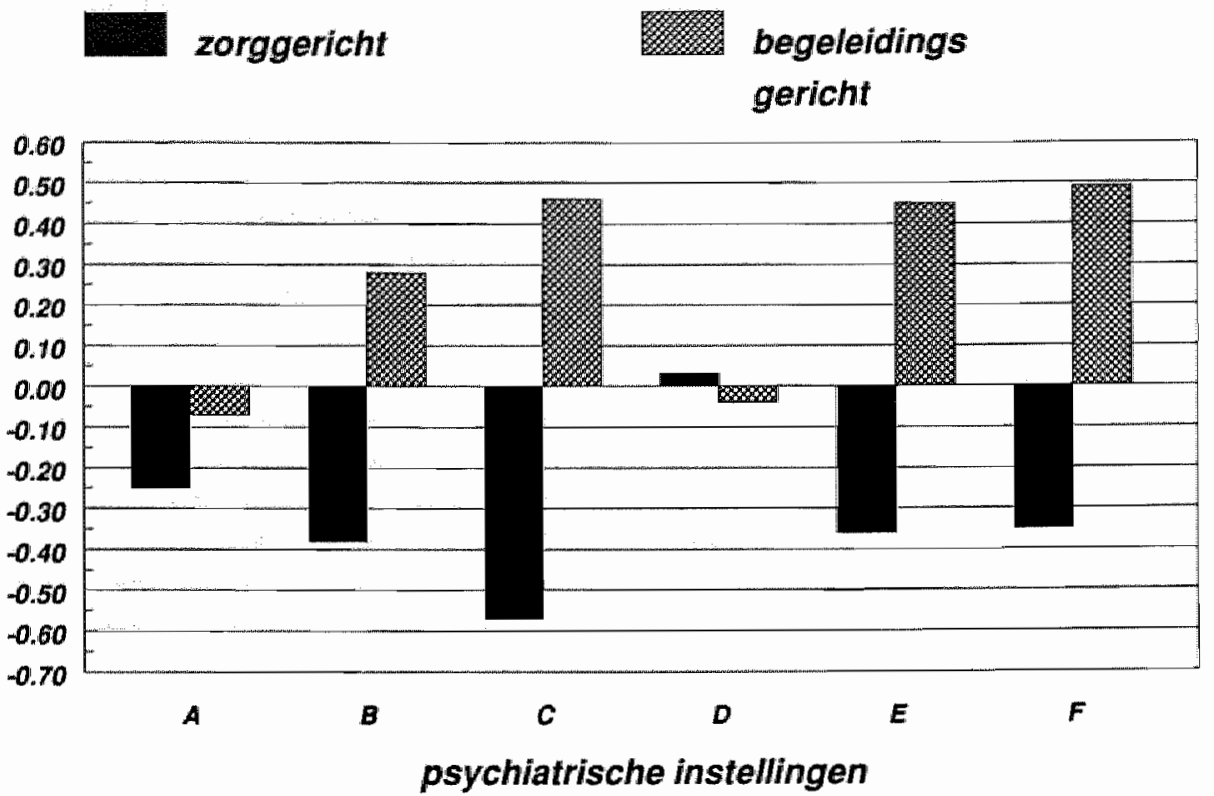

Figuur 7.1.b. Zorg en begeleiding in de shortstay

Figuur 7.1.a/b. maakt duidelijk dat er nogal wat verschillen in taakopvattingen zijn. De taakopvattingen die men als verpleegkundige heeft variëren naar de instelling en de sektor waar men werkzaam is. Mogelijk duidt dit op eigen instellingskultuur. Die kultuur komt namelijk tot uitdrukking in de dingen die mensen doen (Hofstede, 1986).

De regressie-anallyse uit de vorige paragraaf geeft bovendien aan dat de verschillen tussen de instellingen niet veroorzaakt worden door relatief meer leidinggevende of meer ervaren verpleegkundigen in de diverse psychiatrische centra.

In de tot nu toe verrichtte analyses is ervan uitgegaan dat de gevonden verbanden voor alle groepen identiek zijn. Het is echter niet uitgesloten dat bijvoorbeeld naast het algemene effekt van sektor en funktie, leidinggevenden binnen de shortstay wat 
hun taakopvattingen betreft een bijzondere groep vormen. Vandaar dat met behulp van variantie-analyse is nagegaan of mogelijke interakties tussen sektor, funktie en instelling nog extra variantie werklaren van de taakopvattingen (zie Tabel 7.3.).

Tabel 7.3. Driewreg variantie-analyse van de invloed van sektor, funktie en instelling

\begin{tabular}{llll}
\hline variantie & zorg & begeleid & overleg \\
\hline $\begin{array}{l}\text { instelling } \\
\quad \text { funktie } \\
\text { sektor }\end{array}$ & $p<0.02$ & $p<0.001$ & $p<0.002$ \\
& $p<0.001$ & $p<0.001$ & $p<0.001$ \\
& $p<0.001$ & $p<0.001$ & $p<0.001$ \\
$\begin{array}{l}\text { instelling X funktie } \\
\text { instelling X sektor } \\
\text { funktie X sektor }\end{array}$ & $p<0.003$ & $p<0.001$ & \\
instelling X funktie X sektor & & & $p<0.03$ \\
\hline
\end{tabular}

Uit deze analyses blijkt dat de interaktie tussen instelling en sektor nog extra variantie verklaart van de begeleidingsgerichtheid en de zorggerichtheid, terwijl de interaktie tussen funktie en sektor nog variantie van de overleggerichtheid verklaart. Dit laatste wordt veroorzaakt doordat er geen verschil is in overleggerichtheid tussen de leidinggevenden in de longstay en de shortstay. Voor de niet-leidinggevenden is er daarentegen wel verschil tussen de sektoren. De niet-leidinggevende verpleegkundigen in de shortstay zijn meer overleggericht dan hun kollega's in de longstay.

Eerder is reeds gesuggereerd dat er sprake is van een mogelijk verschil in instellingskultuur dat van invloed is op de taakopvattingen. Dit blijkt evenwel niet beperkt te zijn tot een algemene tendens binnen de instellingen, doch ook te verschillen tussen de sektoren in de instellingen.

\section{Funktie en envaringsjaren}

Uit de regressie-analyse van paragraaf 7.2 blijkt dat behalve funktie ook het aantal ervaringsjaren van invloed is op de zorggerichtheid. In Figuur 7.2. is de zorggerichtheid uitgesplitst naar antal jaren ervaring en funktie. Zoals ook uit de regressieanalyse naar voren kwam, is uit Figuur 7.2. af te leiden dat zowel het aantal ervaringsjaren als de funktie elk een afzonderlijk effekt hebben op de mate waarin men gericht is op de persoonlijk zorg. Naarmate men langer werkzaam is en indien men een leidinggevende funktie heeft, richten de psychiatrisch verpleegkundigen zich 
minder op de persoonlijk zorg van patiënten. Toch moeten deze algemene effekten enigszins afgezwakt worden. Uit Figuur 7.2. blijkt immers dat leidinggevenden en niet-leidinggevenden niet verschillen wat zorggerichtheid betreft indien beiden minder dan 5 jaar werkzaam zijn. Pas na 5 jaar ervaring treedt er een verschil tussen beide groepen op, hetgeen met name na 15 jaar ervaring aanzienlijk is.

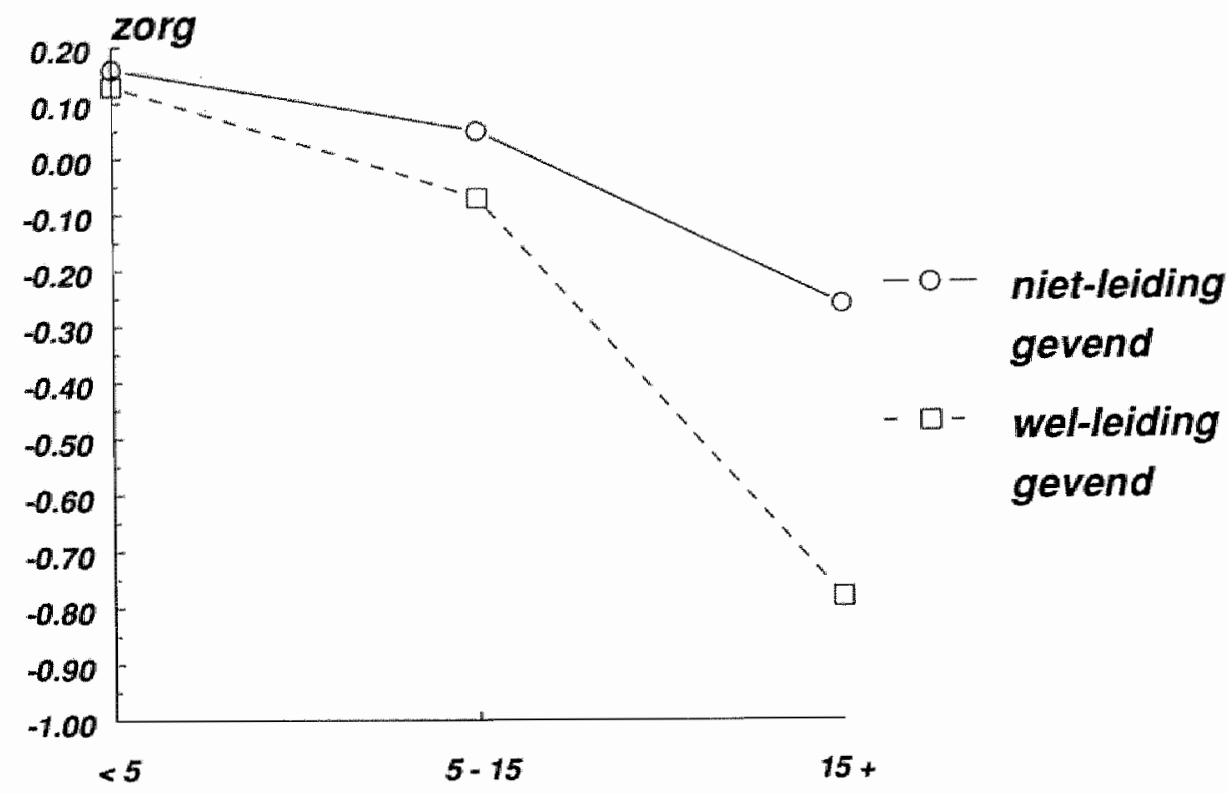

\section{jaren ervaring}

Figuur 7.2. Funktie en ervaringsjaren uitgesplitst naar zorg

Hoewel dit woor leidinggevende sterker geldt, blijkt dat naarmate men meer jaren ervaring heeft men minder aandacht besteedt aan persoonlijke zorg. Kennelijk gelden voor meer ervaren verpleegkundigen andere taken dan voor minder ervarenen, ongeacht het feit of zij nu wel of niet in een leidinggevende funktie werkzaam zijn.

\section{Persoonlijke voldoening en de taakopvattingen}

Persoonlijke voldoening als dimensie van burnout hangt samen met de begeleidingsen overleggerichte taken. uit Tabel 7.1. bleek dat het verband met overlegtaken alleen betrekking heeft op de longstay. Teneinde het samenhang van de taakopvattingen en de persoonlijke voldoening nader te onderzoeken zijn de korrelaties berekend per 
sektor en per instelling. Daarbij is tevens onderscheid aangebracht tussen lleidinggevenden en niet-leidinggevenden (zie Tabel 7.4.).

De struktuur van die korrelaties is alleen eenduidig bij de samenhang tussen de taken met persoonlijke voldoening en overleggerichtheid in de longstay: alle verbanden zijn daar positief. In de shortstay is dat niet het geval, wooral de relatie met leidinggevenden wijkt daar af, doordat dat verband negatief is.

Tussen persoonlijke voldoening en begeleiding zijn in de longstay op eén na alle verbanden positief. Alleen in instelling $F$ is dat verband negatief. In de shortstay is er in de helft van de instellingen een negatief verband en in de andere helft een positief. Het verband tussen leidinggevenden is in beide sektoren positief.

Tabel 7.4. Pearson korrelaties tussen persoonlijke voldoening en de taken naar funktie, instelling en sektor

niet-leidinggevenden

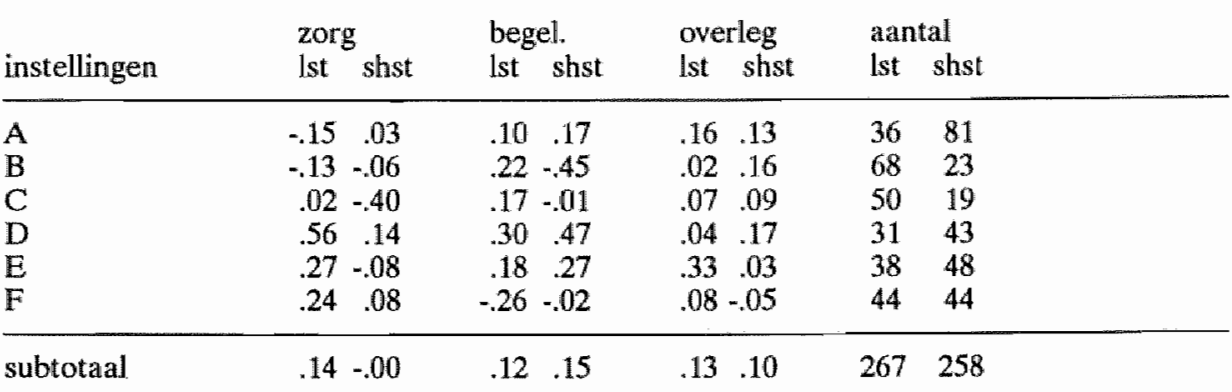

\begin{tabular}{llllllllll} 
leidinggevendlen & -.01 & .21 & .21 & .42 & .18 & -.20 & 84 & 78 \\
\hline totaal & .09 & .03 & .14 & .20 & .14 & .07 & 351 & 336
\end{tabular}

Het verband met zorggerichte taken is eveneens weinig eenduidig, ook hier is in beide sektoren verschil tussen de instellingen. In enkele instellingen is er sprake van signifikante verbanden. Doordat de richting van de verbanden verschilt tussen de instellingen is de korrelatie met de totale groep miniem.

Resumerend kan over het verband tussen persoonlijke voldoening en de taakopvattingen, uitgesplitst naar funktie, sektor en instelling, gekonkludeerd worden dat er tussen persoonlijke voldoening en de taakopvattingen geen robuust verband aantoonbaar is. Verschillen tussen de sektoren en tussen leidinggevenden en niet-leidinggevenden zijn tot op zekere hoogte nog te begrijpen, maar verschillen tussen de instellingen vormen een, althans voorlopig, onopgelost vraagstuk. 


\section{Samenvatting}

In dit hoofdstuk is met behulp van multiple regressie-analyse nagegaan welke van de verklarende variabelen verband houden met de taakopvattingen. Zowel de sektor waar psychiatrisch verpleegkundigen werken, als de instelling en de funktie zijn van invloed op alle drie de komponenten van hun takopvattingen: begeleidings- zorg en overleggerichtheid. Daarbij is er sprake van een interaktie-effekt tussen sektor en de instelling.

Het aantal jaren ervaring hangt niet samen met begeleidingsgerichtheid maar wel met zorggerichtheid. Meer ervaring betekent minder aandacht besteden aan persoonlijke zorg van de patiënt.

Burnout heeft slechts een beperkt effekt op de takopvattingen. Het (al dan niet signifikante) verband tussen persoonlijke voldoening en de taakopvattingen blijkt te verschillen tussen de aan het onderzoek deelnemende psychiatrische centra.

Geen verband bleek tussen de visie op chroniciteit en de taakopvattingen. De eerder (zie hoofdstuk 5) beschreven verbanden tussen geslacht en de taakopvattingen komen volledig voor rekening van overige verklarende variabelen. Dit geldt eveneens voor het al dan niet beschikken over een diploma inrichtingswerk.

De belangrijkste konklusie uit het onderzoek betreft de verschillen tussen psychiatrische centra ten aanzien van de taakopvattingen van de aldaar werkende psychiatrisch verpleegkundigen. 


\section{SLOTBESCHOUWING}

\section{Inleiding}

In deze slotbeschouwing zullen op de eerste plaats de belangrijkste bevindingen uit het onderzoek behandeld worden. Daarna volgt een diskussie over de gevonden resultaten. Tot slot worden enkele beperkingen van het onderzoek besproken en zullen aanbevelingen voor verder onderzoek gedaan worden.

\subsection{Konklusies}

De eerste probleemstelling van dit onderzoek heeft betrekking op de taakopvattingen van psychiatrisch verpleegkundigen ten behoeve van de zorg voor de chronische psychiatrische patiënt. Aan de hand van een literatuurverkenning werd duidelijk dat die taken te beschouwen zijn als een afgeleide van de funkties van de psychiatrische instellingen. Een belangrijke ontwikkeling in de psychiatrische centra is de gewijzigde zorg voor de chronische patiënten. Uitgaande van de gedachte dat institutionalisering leidt tot het 'chronisch' worden van psychiatrische patiënten is men steeds meer de madruk gaan leggen op het bevorderen van de zelfstandigheid van deze mensen. Van verpleegkundigen wordt daarbij verwacht dat zij hun traditionele verplegersrol inruilen voor die van begeleider. Deze tendens wordt in dit onderzoek bevestigd. Psychiatrisch verpleegkundigen blijken namelijk hun aktiviteiten in de alledaagse zorg voor de patiënt te willen verminderen en de (agogisch) begeleidende aktiviteiten te willen uitbreiden. Dit geldt zowel voor verpleegkundigen die in longstay-afdelingen werken, als voor verpleegkundigen die in shortstay-afdelingen werkzaam zijn.

Verpleegkundigen die in de longstay werken besteden relatief de meeste tijd aan de persoonlijke verzorging van de patiënten. In de shortstay wordt de meeste tijd besteed aan kontakten met kollega's en/of andere disciplines. In beide sektoren wordt de minste tijd besteed aan begeleiding bij het huishouden. In het algemeen geeft men aan van alle aktiviteiten het vaakst (agogisch) begeleidende aktiviteiten te verrichten.

Doordat bij de meting van de taakopvattingen enkele onderzoekstechnische problemen optraden konden de taakopvattingen verder alleen bestudeerd worden wat de ervaren feitelijkheid betreft. Met behulp van faktoranalyse werd daartoe onderscheid aangebracht in drie taakdimensies. De indeling van de aktiviteiten bestaat uit: zorgbegeleidings- en overleggerichte aktiviteiten. Onder de zorggerichte aktiviteiten wordt verstaan de begeleiding bij de alledaagse persoonlijke zorg en de begeleiding bij het huishouden. Begeleidingsgerichte aktiviteiten betreffen de begeleiding op psycho- 
sociaal vlak en bet samen met patiẻnten aktiviteiten ondernemen. Overleggerichte aktiviteiten betreffen het overleg van verpleegkundigen met familie van patiënten en met andere disciplines.

Van belang is in dit verband de vergelijking van deze aan empirisch materiaal ontleende indeling met de indeling van Kramer (1970) en met die van Van Bergen en Hollands (1978). Zowel bij deze auteurs als in het onderhavige onderzoek is dezelfde indeling in 'handelingen gericht op de dagelijkse zorg' en 'agogische handelen" onderscheiden. Opmerkelijk daarbij is vooral dat Van Bergen en Hollands oorspronkelijk uitgingen van een somatische deficiëntie. Hun indeling blijkt ook van toepassing wanneer een deficiëntie op psycho-sociaal vlak de aanleiding tot de zorgverlening is.

Ontwikkelingen in de visie op de problematiek van chronische psychiatrische patiënten heeft geleid tot veranderingen in de geestelijke gezondheidszorg. Verondersteld werd daarom dat die visie samen zou hangen met de visies van psychiatrisch verpleegkundigen op chroniciteit. Dit kon, uitgaande van een meetinstrument dat onderscheid maakt in ziektethese en hospitalisatiethese, in dit onderzoek niet bevestigd worden. Tussen de taakopvattingen en de visie op chroniciteit werd namelijk geen verband aangetoond.

Veranderingen in de psychiatrische centra hebben geleid tot een diskussie omtrent de beroepsidentiteit van psychiatrisch verpleegkundigen. In het onderzoek werd daarom nagegaan of de beroepsidentifikatie verband houdt met de taakopvattingen. Daarbij werden twee beroepsrollen onderscheiden: die van verpleegkundige en die van therapeut. Slechts in beperkte mate blijkt in het onderzoek samenhang tussen de taakopvattingen en beroepsidentifikatie, namelijk dat degenen die zich meer met de therapeutische beroepsrol identificeren meer begeleidingsgericht zijn. Verpleegkundigen die zich meer met de verpleegkundige beroepsrol identificeren doen meer aan overlegtaken.

Tijdens de oriëntatiefase van het onderzoek werd door verscheidene funktionarissen gewezen op het belang van het verschijnsel burnout. Onder burnout wordt verstaan het optreden van emotionele uitputting, depersonalisatie en verminderde persoonlijke voldoening. Burnout zou leiden tot een afname van de kwaliteit van de zorgverlening. In dit verband betekent dit, dat een hoge mate van burnout leidt tot minder begeleidingsgericht en mogelijk meer zorggericht zijn. De bevindingen uit het onderzoek tonen evenwel slechts verband aan tussen burnout en begeleidingsgerichte aktiviteiten. Daarbij betreft het een positief verband tussen persoonlijke voldoening en emotionele uitputting. Hoe hoger de burnout hoe minder men aan begeleidingsgerichte aktiviteiten doet. Dit wijst inderdaad in de richting van een verband tussen 
burnout en de kwaliteit van de zorgverlening. Immers begeleiden is een belangrijke komponent van de taak van de psychiatrisch verpleegkundige. Aangetekend dient hierbij wel te worden dat de verbanden tussen persoonlijke voldoening en de taakopvattingen fluktueren tussen de instellingen en de sektoren. Een algemene konklusie kan alleen met het nodige voorbehoud gemaakt worden. Gezien de wijze van gegevensverzameling (transversaal) kan geen causale interpretatie aan de resultaten toegekend worden, hoewel de aard van de verbanden tussen burnout en de taakopvattingen hiertoe uitnodigen.

Hoewel tijdens het vooronderzoek de indruk ontstond dat taken zouden verschillen tussen mannen en vrouwen bleek dit niet in het onderzoek bevestigd te worden. Multivariate analyse toont aan dat de verschillen die er in takopvattingen tussen mannen en vrouwen bestaan samenhangen met verschillen in andere kenmerken, zoals mogelijk funktie, ervaring en sektor.

Dat de taken verschillen tussen leidinggevenden en niet-leidinggevenden zal niemand verbazen. Interessant daarbij is evenwel dat eenzelfde verschil in zorgtaken ook bestaat tussen niet-leidinggevende verpleegkundigen die relatief weinig jaren ervaring hebben en verpleegkundigen die relatief lang in de psychiatrie werkzaam zijn als teamverpleegkundige.

Verpleegkundigen die een opleiding inrichtingswerk gevolgd hebben zouden, zo werd verondersteld, meer begeleidingsgericht zijn dan kollega's zonder zo'n opleiding. Hoewel dit inderdaad aangetroffen werd bleek ook hier dat dit verschil toe te schrijven is aan andere kenmerken, zoals mogelijk de instelling waar men werkzaam is.

Een belangrijke konklusie uit het onderzoek is dat de takopvattingen verschillen tussen de instellingen. $\mathrm{Z}_{0}$ zijn er instellingen die meer zorggericht zijn en andere die meer begeleidingsgericht zijn. Gelijksoortige verschillen zijn er ook tussen de longstay en de shortstay-afdelingen. De longstay-afdelingen zijn overwegend meer zorggericht. De shortstay-afdelingen zijn meer begeleidingsgericht. Echter tussen de instellingen is geen eenduidig noch vast patroon tussen de sektoren aantoonbaar. Zo komt het bijvoorbeeld voor dat binnen een instelling de shortstay meer zorggericht is dan de longstay. Verschillen in taakopvattingen variëren, zowel tussen de instellingen, als tussen de sektoren. 


\subsection{Diskussie}

\section{Verschillen in taakopvattingen tussen de instellingen}

De belangrijkste konklusie uit het onderzoek is, dat er verschillen in taakopvattingen van psychiatrisch verpleegkundigen zijn die alleen verklaard kunnen worden als verschillen tussen de instellingen waar zij werkzaam zijn. Daarbij is eveneens sprake van verschillen tussen de sektoren long-en shortstay, zowel onderling als tussen de aan het onderzoek deelnemende instellingen.

Deze verschillen geven aan dat er geen eenduidige opvatting is over de verschillen in zorgverlening tussen de longstay en de shortstay. Dit betekent dat een gelijksoortig verpleegprobleem niet samengaat met gelijke taakopvattingen van verpleegkundigen in de diverse psychiatrische centra. Met andere woorden: tussen de instellingen en de sektoren is in de zorg voor de psychiatrische patiënt geen eensluidend beeld aangetroffen. Niet de psychiatrische werpleging (als discipline) bepaalt kennelijk de wijze van aanpak. Dit bevestigt de afwezigheid van een sterke professionele autonomie van de verpleging. Psychiatrisch verplegen wordt hiermee bevestigd als een funktie binnen de psychiatrisch instellingen. De aard en de inhoud van die funktie wordt mede bepaald door de instelling en niet door de psychiatrische verpleegkunde als beroep en of vakgebied alleen. Hoewel dit onderzoek geen verklaring biedt voor de gevonden verschillen in taakopvattingen van verpleegkundigen tussen de deelnemende instellingen, is het denkbaar dat de verschillen terug te voeren zijn tot verschillen in instellingskultuur.

Zoals reeds gesteld in hoofdstuk 3 is de continuïteit van de eigen instellingskultuur mogelijk doordat het overgrote deel van het personeel (de verpleging) in eigen beheer opgeleid wordt.

Verschillen tussen de instellingen zijn op zich viteraard niet erg. Het verschil in taakopvattingen tussen de sektoren en de instellingen is evenwel niet bevorderlijk voor de uitwisseling van personeel, aangezien de zorg dan niet aan de verwachtingen voldoet. Ook stagiaires van dagopleidingen kunnen geen eenduidig beeld van de zorg ten behoeve van een bepaalde patiëntenkategorie krijgen.

Een eventuele herbezinning op de B-opleiding als in-service opleiding dient derhalve niet alleen vanuit sociaal-ekonomisch en/of onderwijskundig oogpunt, doch ook in het kader van de rol bij de instandhouding van verschillen tussen de instellingen plaats te winden. 


\section{Chroniciteit}

De visie op chroniciteit als hospitalisatie- danwel als ziektethese blijkt geen samenhang met de taakopvattingen te vertonen. De vraag of men chronische patiënten ziek danwel gehospitaliseerd vindt blijkt niet relevant voor de taakopvattingen van psychiatrisch verpleegkundigen. Op zich is dat opmerkelijk, aangezien de hospitalisatiegedachte wel geleid heeft tot aanpassing van de zorg in de instituten. Tussen de instellingen worden wel verschillen in de visie op chroniciteit aangetoond. Op individueel niveau nemen verpleegkundigen die visies kennelijk niet over in hun takgerichtheid.

Een andere verklaring voor het ontbreken van verbanden bestaat daaruit dat de visies, zoals geoperationaliseerd mogelijk niet van belang zijn voor de taakopvattingen. Immers niet de etiologie, doch het aktuele gedrag van de patiënt is relevant voor de verpleegkundige. In die zin zou wellicht de handicapthese meer relevant zijn voor de verpleging.

\section{Burnout}

Verbanden tussen burnout en de taakopvattingen konden slechts in beperkte mate aangetoond worden. Naarmate verpleegkundigen meer onderhevig zijn aan burnout verrichten zij minder begeleidende gesprekken. Ofschoon dit verband tamelijk plausibel is en de verwachte richting van het verband tussen burnout en taakopvattingen ondersteunt, dient deze konklusie toch met enig voorbehoud gemaakt te worden. Op de eerste plaats is het niet mogelijk om met behulp van de gekozen onderzoeksmethode uitspraken over causaliteit te doen. Op de tweede plaats blijkt het verband verre van robuust.

Hoewel dit onderzoek niet bedoeld is om verschillen in burnout te verklaren, viel toch het verschil in burnout tussen de sektoren op. In de literatuur wordt juist gewezen op het risiko van burnout voor verpleegkundigen die in de longstay werken (Lamb, 1979; Wollants, 1987). De reden daarvoor zou gelegen zijn in het feit dat men daar weinig resultaten boekt met patiënten. Uit het onderzoek blijkt dat juist in de shortstay de burnout hoger is. Daarvoor zijn verschillende verklaringen mogelijk.

Ofschoon in de longstay geboekte resultaten minder spectaculair zijn, zijn deze door thet ontbreken van vele andere disciplines, wel eerder toe te schrijven aan het handelen van de verpleging. Van de in de shortstay geboekte resultaten is het veel minder zo niet onmogelijk om aan te geven wiens bijdrage daarvoor verantwoordelijk is. 
Uiteraard kan het verschil ook toe te schrijven zijn aan selektie. Het is denkbaar dat juist diegenen in de longstay gaan werken (of blijwen werken) die zich aangetrokken voelen tot de zorgverlening die daar van verpleegkundigen werwacht wordt. In deze verklaring past de volgende opmerking van een van de geïnterviewden: "Verpleegkundigen in de long-en de shortstay zijn ander slag volk".

Burnout is het gevolg wan het niet op adekwate wijze om kunnen gaan met arbeidsstress. Juist het werk in de shortstay gaat gepaard met veel onverwachte situaties. In de longstay is het in het algemeen rustiger, meer routinematig, werken. In die zin zou eerder in de shortstay dan in de longstay een hogere burnout onder het verplegend personeel verwacht worden. Ofschoon de onderzoeksbevindingen deze verklaring lijken te bevestigen, vereist het verschil in burnout tussen de sektoren nader onderzoek. Dit verschil is daarbij een interessant aanknopingspunt voor onderzoek naar de determinanten van burnout.

\section{Identifikatie}

Uit het vooronderzoek werd de konklusie getrokken dat de helft van de B-verpleegkundigen zich niet als verpleegkundige beschouwde. De enquête bevestigde dit niet. Het onderscheid tussen 'verpleegkundige' en 'therapeut zijn' bleek minder aanwezig dan verwacht werd op basis van de interviews en de literatuur.

Het feit dat psychiatrisch verpleegkundigen zich meer met verplegen identificeren dan op basis van de interviews verwacht werd, wijst er mogelijk op dat men zich toch meer verpleegkundige voelt dan men in gesprekken doet voorkomen. Anderzijds is de identifikatie met therapeuten ten onrechte geïnterpreteerd als niet-identifikatie met verplegen. Het onderscheid tussen verplegen en behandelen lijkt daarmee, althans voor een deel van de respondenten niet wezenlijk te zijn. De diskussie dient niet te gaan om de vraag of psychiatrisch verpleegkundigen verpleegkundig en/of therapeutisch bezig zijn, maar hoe de aksenten in de kombinatie van beide liggen.

In het onderzoek is ook aangetoond dat een deel van de respondenten zich noch met de verpleegkundige, noch met de therapeutische beroepsrol identificeert. Mogelijk is hier sprake van een geheel ander beroepsbeeld. Hoewel dat juist te verwachten is in de longstay zijn geen verschillen in beroepsidentifikatie tussen de sektoren aangetoond.

Duidelijk wordt wel uit de bevindingen dat er geen sprake is van een eenduidige beroepsidentifikatie. Dit wijst er mogelijk op dat psychiatrisch verplegen eerder gezien dient te worden als een funktie binnen de psychiatrische centra dan als een beroep met een duidelijke eigen autonomie. 


\section{Opleiding inrichtingswerk.}

Elf procent van de respondenten aan het onderzoek heeft naast de B-opleiding ook een opleiding inrichtingswerk gevolgd. In tegenstelling tot wat werwacht werd is de beroepsidentifikatie van beide groepen niet geheel verschillend. Verpleegkundigen/inrichtingswerkers identificeren zich niet meer met 'therapeut-zijn', maar wel minder met 'verpleegkundige-zijn', dan hun kollega's zonder een opleiding inrichtingswerk. Uit de analyses blijkt dat verpleegkundigen/inrichtingswerkers meer begeleidingsgericht zijn. Hier is dus sprake van een indirekt verband tussen 'inrichtingswerk" en de taakgerichtheid.

Het is opmerkelijk dat verpleegkundigen een opleiding inrichtingswerk volgen. Beide opleidingen, de B-opleiding en de opleiding inrichtingswerk, zijn tot op zekere hoogte uitwisselbaar, getuige bijvoorbeeld personeelsadvertenties waarin gevraagd wordt naar iemand met hetzij een B-diploma, hetzij een diploma inrichtingswerk. Het feit dat verpleegkundigen een opleiding inrichtingswerk als 'vervolgopleiding' beschouwen is mogelijk te wijten aan het ontbreken van adekwate verpleegkundige vervolgopleidingen voor B-verpleegkundigen. Indien het volgen van een opleiding inrichtingswerk alleen de funktie heeft van het volgen van verdere studie, het ligt het in de lijn der verwachting dat de belangstelling voor de opleiding inrichtingswerk afneemt. Tegenwoordig is het mamelijk mogelijk om na het B-diploma de 'vrijstellingen-H.B.O.V.' te volgen. Dit is een verkorte opleiding die men eventueel parttime kan volgen. De H.B.O.V. kan daardoor een alternatief zijn voor de opleiding inrichtingswerk.

Doordat het onderzoek om technische redenen beperkt bleef tot de feitelijkheid van de taakopvattingen kon niet nagegaan worden of de wenselijke taakopvattingen verschilden tussen verpleegkundigen met of zonder een opleiding inrichtingswerk. Het is niet uitgesloten dat inrichtingswerkers wel een andere opvatting over hun wenselijke taken hebben.

\section{Persoonskenmenken}

Taakopvattingen worden in belangrijke mate bepaald door funktie. Daarnaast heeft ook het aantal jaren ervaring effekt op de taakopvattingen. De verdeling van met name zorggerichte taken onder gediplomeerden is niet alleen afhankelijk van de formele funktie, doch ook van de ervaring die men heeft. Naast de formele hiërarchie bestaat er kennelijk een informele hiërarchie. In beide gevallen (leidinggeven of langdurige werkervaring, leidt deze tot het minder uitvoeren van zorggerichte aktiviteiten. Ook is het mogelijk dat naarmate men langer ervaring heeft men meer befrokken is bij de begeleiding van leerlingen, en daardoor minder aan direkte patiëntenzorg doet. De begeleiding van leerlingen hoeft namelijk niet voorbehouden te zijn aan leidinggevenden. Het is evenwel ondenkbaar dat dit zoveel tijd in beslag neemt dat daardoor geen tijd meer over zou zijn voor de direkte zorgverlening. 


\subsection{Beperkingen en aanbevelingen}

Bij de konstruktie van de meetschalen woor de taakopvattingen ontstond een onderzoekstechnisch probleem (zie hfdst.5). Daarvoor werd een oplossing gevonden door een strengere selektie toe te passen voordat een respondent de skore 'vaak' toegekend wordt. Dit is mogelijk aangezien ook gegevens gevraagd zijn over de relatieve tijdsbesteding van de aktiviteiten. De op deze wijze verkregen skores geven een betrouwbaarder beeld van de aktiviteiten dan de afzonderlijke antwoorden op de vragen over de aktiviteiten. Over de wenselijke taakopvattingen is slechts in beschrijvende zin informatie verkregen.

Een beperking van dit onderzoek betreft de wijze waarop taakopvattingen gemeten zijn. De vragen zijn namelijk afgeleid uit interviews met verpleegkundigen die op longstay-afdelingen werken. Dit impliceert dat mogelijk een aantal taken die op de shortstay voorkomen buiten beschouwing gelaten zijn. Alle gestelde vragen blijken evenwel relevant voor verpleegkundigen uit beide sektoren. Alleen de mate waarin de aktiviteiten verricht worden verschilt tussen de longstay en de shortstay.

Een laatste beperking heeft betrekking op het feit dat de aktiviteiten alleen naar frekwentie gemeten zijn. De doelstelling ervan blijft in dit onderzoek buiten beschouwing. Uit een recentelijk afgeronde doctoraalstudie (Hermans, 1988) is gebleken dat dezelfde aktiviteiten verschillende doelen kunnen dienen, afhankelijk van de situatie. Dit pleit ervoor om bij nader onderzoek naar de taken van psychiatrisch verpleegkundigen ook de doelstelling van de taken te betrekken.

Bij de interpretatie van de taakopvattingen is ervan uitgegaan dat de verschillen tussen de instellingen als absolute verschillen gezien kunnen worden. Een andere mogelijkheid is, dat verschillen tussen de instellingen in behandeling van de patiënten minder absoluut zijn, doch samenhangen met verschillen in arbeidsverdeling tussen gediplomeerden en leerlingen en/of andere disciplines. In dat geval zouden de verschillen dus toegeschreven moeten worden aan de selekte steekproef, die voor dit onderzoek enkel uit gediplomeerde verpleegkundigen bestaat. Hoewel de werkverdeling tussen gediplomeerden en leerlingen in principe de reden van de gevonden verschillen zou kunnen verklaren, lijkt dit toch niet aannemelijk. In sommige instellingen zijn psychiatrisch verpleegkundigen namelijk vooral zorggericht. Het is onwaarschijnlijk dat juist de leerlingen de psycho-sociale begeleiding uitvoeren en de gediplomeerden de zorg voor de alledaagse aktiviteiten voor hun rekening nemen. Wel is het mogelijk dat zorgtaken in sommige instellingen meer door huishoudelijk personeel en begeleidingstaken meer door overige disciplines verricht worden.

Een volgende beperking van dit onderzoek betreft het feit dat er enkel een indeling in longstay en shortstay-afdelingen is gemaakt. Binnen deze sektoren is er een diversiteit aan afdelingsdoelstellingen. In volgend onderzoek zouden de taken daarom nader 
gespecificeerd moeten worden naar afdelingsdoelstellingen, c.q. zorgbehoeften van de patiënten. Daarbij zouden bijvoorbeeld ook verschillen in verpleegsystemen een aandachtspunt kunnen zijn.

Bij dit onderzoek is alleen gebruik gemaakt van de meningen van psychiatrisch verpleegkundigen. Het is aan te bevelen om bij verder onderzoek ook de meningen van patiënten te betrekken. Aan patiënten zou bijwoorbeeld gevraagd kunnen worden wat zij verwachten van psychiatrisch verpleegkundigen.

Eerder werd opgemerkt dat de operationalisering van de visie op burnout wellicht niet aansluit bij datgene wat relevant is voor de psychiatrische verpleging. In een volgend onderzoek is het daarom aan te bevelen om (eventueel naast de hier gebruikte schaal) de visie op chroniciteit op een andere wijze te meten. Het is immers niet uitgesloten dat het ontbreken van verbanden tussen genoemde visie en de taakopvattingen te wijten zijn aan het gebruikte meetinstrument.

Verder onderzoek naar burnout is om verschillende redenen van belang. Het optreden van burnout is namelijk niet alleen nadelig voor de persoon in kwestie, doch ook voor de continuïteit en de kwaliteit van de zorgverlening. Bij vervolgonderzoek zou de nadruk vooral moeten liggen op de relatie tussen burnout en de kwaliteit van de zorgverlening.

Tot slot volgt een aanbeveling over nader onderzoek naar de verschillen tussen de instellingen. Deze verschillen geven aan dat men in sommige instellingen meer begeleidingsgericht is, c.q. meer handelt volgens de anti-hospitalisatiegedachte dan in andere, waar men meer zorggericht is. Aangezien daarmee in zekere zin een aspekt van de kwaliteit van de hulpverlening bepaald wordt, is verder onderzoek naar de verschillen tussen de instellingen geboden. Gedacht kan daarbij worden aan onderzoek naar de (kwaliteit van) zorgverlening van bepaalde patiëntenpopulaties, waarbij bijvoorbeeld gebruik gemaakt zou kunnen worden van case-studies in verscheidene psychiatrische centra. Het aksent zou daarbij moeten liggen op het vergelijken van het zorgaanbod tussen de instellingen. 


\section{SAMENVATTING}

In dit boek wordt verslag gedaan van een onderzoek naar taken wan psychiatrisch verpleegkundigen. Aan de hand van een literatuurverkenning werd duidelijk dat die taken te beschouwen zijn als een afgeleide van de funkties van de psychiatrische instellingen. Een belangrijke ontwikkeling in de psychiatrische centra is de gewijzigde zorg voor de chronische patiënten. Uitgaande van de gedachte dat institutionalisering leidt tot het 'chronisch' worden van psychiatrische patiënten is men steeds meer de nadruk gaan leggen op het bevorderen van de zelfstandigheid van de patiënten. Van verpleegkundigen wordt daarbij verwacht dat zij hun traditionele verplegersrol inruilen voor die van begeleider. Ontwikkelingen in de geestelijke gezondheidszorg gaan zodoende gepaard met veranderingen in de taken van psychiatrisch verpleegkundigen. De veranderingen in de psychiatrische centra hebben daardoor geleid tot, wat wel omschreven wordt als: de identiteitskrisis van de psychiatrische verpleging.

Het onderzoek, waaraan verpleegkundigen uit tien psychiatrische centra deelgenomen hebben, bestaat uit interviews en een schriftelijke enquête. De interviews met 52 verpleegkundigen uit 5 verschillende psychiatrische centra dienden ter oriëntatie. De gegevens uit de interviews zijn tevens gebruikt voor het samenstellen van een enquête. Deze enquête werd voorgelegd aan \pm 1150 verpleegkundigen uit 6 psychiatrische centra. De respons bedroeg $78 \%$, hetgeen neerkomt op een nagenoeg 900 deelnemers aan het uiteindelijk onderzoek.

In het onderzoek is nagegaan of er samenhang bestaat tussen de taakopvattingen van psychiatrisch verpleegkundigen en hun visie op de problematiek van de chronische patiënt; de beroepsidentifikatie; burnout en enkele persoonskenmerken. Tevens is nagegaan of het uitmaakt of verpleegkundigen al dan niet bij chronische psychiatrische patiënten werkzaam zijn en of er verschillen zijn in taakopvattingen die samenhangen met de psychiatrische instelling waar zij werkzaam zijn.

Uit het onderzoek blijkt dat psychiatrisch verpleegkundigen hun aktiviteiten in de alledaagse zorg voor de patiënt willen verminderen en de (agogisch) begeleidende aktiviteiten willen uitbreiden. Dit geldt zowel voor verpleegkundigen die in longstayafdelingen werken, als voor verpleegkundigen die in shortstay-afdelingen werkzaam zijn.

Verpleegkundigen die in de longstay werken besteden relatief de meeste tijd aan de persoonlijke verzorging van de patiënten. In de shortstay wordt de meeste tijd besteed aan kontakten met kollega's en/of andere disciplines. In beide sektoren wordt de 
minste tijd besteed aan begeleiding bij het huishouden. In het algemeen zegt men het vaakst (agogisch) begeleidende aktiviteiten te verrichten.

Met behulp van faktoranalyse werd onderscheid aangebracht in drie taakdimensies. Deze indeling van de aktiviteiten bestaat uit: zorg-begeleidings- en overleggerichte aktiviteiten. Onder de zorggerichte aktiviteiten wordt verstaan de begeleiding bij de alledaagse persoonlijke zorg en de begeleiding bij het huishouden. Begelleidingsgerichte aktiviteiten betreffen de begeleiding op psycho-sociaal vlak en het samen met patiënten aktiviteiten ondernemen. Overleggerichte aktiviteiten betreffen het overleg van verpleegkundigen met familie van patiënten en met andere disciplines.

Van belang is in dit verband een vergelijking van deze aan empirisch materiaal ontleende indeling met een indeling uit de literatuur. Zowel in het onderhavige onderzoek als in de literatuur is dezelfde indeling in 'handelingen gericht op de dagelijkse zorg" en 'agogische handelen' onderscheiden. Opmerkelijk daarbij is dat bij de indeling uit de literatuur uitgegaan werd van een somatische deficiëntie als uitgangspunt voor het verpleegkundig handelen. De indeling blijkt, zo toont het onderzoek, ook van toepassing wanneer een deficiëntie op psycho-sociaal vlak de aanleiding tot de zorgverlening is.

De visie op de problematiek van chronische psychiatrische patiënten heeft geleid tot veranderingen in de geestelijke gezondheidszorg. Verondersteld werd daarom dat die visie samen zou hangen met visies van psychiatrisch verpleegkundigen op chroniciteit. Dit kon, uitgaande van een meetinstrument dat onderscheid maakt in ziekte-these en hospitalisatiethese, in dit onderzoek niet bevestigd worden. Tussen de taakopvattingen en de visie op chroniciteit werd namelijk geen verband aangetoond. Veranderingen in de psychiatrische centra hebben geleid tot een diskussie omtrent de beroepsidentiteit van psychiatrisch verpleegkundigen. In het onderzoek is daarom nagegaan of de beroepsidentifikatie verband houdt met de taakopvattingen. Daarbij werden twee beroepsrollen onderscheiden: die van verpleegkundige en die van therapeut. Slechts in beperkte mate blijkt er in het onderzoek samenhang tussen de taakopvattingen en beroepsidentifikatie. Dat wil zeggen dat degenen die zich meer met de therapeutische beroepsrol identificeren meer begeleidingsgericht zijn. Verpleegkundigen die zich meer met de verpleegkundige beroepsrol identificeren doen meer aan overlegtaken.

Tijdens de oriëntatiefase van het onderzoek werd door verscheidene funktionarissen gewezen op het belang van het verschijnsel burnout. Onder burnout wordt verstaan het optreden van emotionele uitputting, depersonalisatie en verminderde persoonlijke voldoening. Burnout zou leiden tot een afname van de kwaliteit van de zorgverlening. In dit verband is betekent dit, dat een hoge mate van gevoelens van burnout leidt tot minder begeleidingsgericht en mogelijk meer zorggericht zijn. De bevindingen uit het onderzoek tonen evenwel slechts verband aan tussen burnout en begeleidingsgerichte 
aktiviteiten. Daarbij betreft het een positief verband tussen persoonlijke voldoening en emotionele uitputting. Hoe hoger de burnout hoe minder men aan begeleidingsgerichte aktiviteiten doet. Een algemene konklusie hieromtrent kan slechts met enig voorbehoud gemaakt worden. Gezien de wijze van gegevensverzameling (transversaal) kan geen causale interpretatie aan de resultaten toegekend worden, hoewel de aard van de verbanden tussen burnout en de taakopvattingen hiertoe uitnodigen. Ofschoon tijdens het vooronderzoek de indruk ontstond dat taken zouden verschillen tussen mannen en vrouwen bleek dit niet in het onderzoek bevestigd te worden. Multivariate analyse toont aan dat de verschillen die er in takkopvattingen tussen manmen en vrouwen bestaan samenhangen met verschillen in andere kenmerken, zoals mogelijk funktie, ervaring en sektor.

Het al dan niet bezitten van een diploma inrichtingswerk leidt tot verschillen in opvattingen over chroniciteit. Verpleegkundige/inrichtingswerkers zijn meer voorstander van de hospitalisatiethese en minder voorstander van de ziektethese dan hun collega's die geen opleiding inrichtingswerk gevolgd hebben. Het bezitten van een opleiding inrichtingswerk hangt evenwel niet rechtstreeks samen met verschillen in taakopvattingen.

Dat de taken verschillen tussen leidinggevenden en niet-leidinggevenden zal niemand verbazen. Interessant daarbij is dat eenzelfde verschil in zorgtaken ook bestaat tussen niet-leidinggevende verpleegkundigen die relatief weinig jaren ervaring hebben en verpleegkundigen die relatief lang in de psychiatrie werkzaam zijn als teamverpleegkundige.

Een van de belangrijkste konklusies uit het onderzoek is dat de taakopvattingen verschillen tussen de instellingen. Zo zijn er instellingen die meer zorggericht zijn en andere die meer begeleidingsgericht zijn. Gelijksoortige verschillen zijn er ook tussen de longstay en de shortstay-afdelingen. Het verschil tussen de sektoren ligt voor de hand, gezien de verschillen in patiëntenpopulaties. Verpleegkundigen die op longstay-afdelingen werken zijn overwegend meer zorggericht. Hun kollega's uit de shortstay zijn meer begeleidingsgericht. Echter tussen de instellingen is er geen eenduidig moch vast patroon tussen de sektoren. Zo komt het bijvoorbeeld voor dat men binnen één instelling in de shortstay meer zorggericht is dan in de longstay. Verschillen in taakopvattingen variëren, zowel tussen de instellingen, als tussen de sektoren. Over de oorzaken van die verschillen geven de onderzoeksbevindingen geen verklaring. Mogelijk worden de verschillen veroorzaakt door verschillen in beleid en/of instellingskultuur. Nader onderzoek zal dat moeten uitwijzen. In ieder geval lijkt het van belang om dergelijk onderzoek te verrichten, aangezien de verschillen tussen de sektoren en instellingen in zekere zin beschouwd kunnen worden als kwaliteitsverschillen in de zorgverlening. 


\section{LIJST MET GEBRUIKTE AFKORTINGEN}

A-opleiding, de in-service opleiding tot verpleegkundige die door de algemene ziekerihuizen verzorgd wordt.

B-opleiding, De in-service opleiding tot psychiatrisch verpleegkundige.

C.B.S., Centraal Bureau voor de Statistiek.

G.H.I.V., Geneeskundige Hoofdinspektie voor de Volksgezondheid.

H.B.O.V ${ }_{*,}$ Hogere Beroepsopleiding Verpleegkunde.

I.W., Opleiding inrichtingswerk.

M.B.O.V. Middelbare Beroepsopleiding Verpleegkunde.

N.c.G.v., Nationaal centrum voor de Geestelijke Volksgezondheid.

N.R.V., Nationale Raad voor de Volksgezondheid.

N.Z.I., Nationaal Ziekenhuis Instituut.

Z-opleiding, De in-service opleiding tot verpleegkundige in de zwakzinnigenzorg.

LST., Longstay

SHST, $\quad$ Shortstay

gem. gemiddeld

$\mathrm{g} / \mathrm{m} \quad$ geen mening

n aantal in absolute getallen

s.d. standaarddeviatie 


\section{LITERATUUR}

Algera, J.A. Taakkenmerken, in: P.J.D. Drenth, e.a.(red.), Handboek Arbeids- en Onganisatiepsychologie I, Van Loghem Slaterus, Deventer, 1984.

Altschul, A.T., 'A systems approach to the nursing process", Journal of Advanced Nursing, 3, 1978 , blz. $333-340$.

Andel, H. Van, 'Beleidspsychiatrie' Tijdschrift woor Psychiatrie, 22, 1980, blz. 380 - 393.

Bakker-Van der Kooij, C., "Honderd jaar krankzinnigheid, verslag van een sympositum over de geschiedenis van de krankzinnigenwetgeving in Nederland', Tijdschrift woor Ziekenverpleging, 37, 1984, blz. 17.

Bambang Oetomo, R., Van Asyl tot revalidatiecentrum, Wolters Noordhoff, Groningen, 1970.

Bambang Oetomo, R., 'Patiënt arts en verpleegkundige; hun onderlinge betrekkingen, toen en nu'. Tijdschrift woor Psychiatrie, 16, 1974, blz. 387 - 413.

Barton, R., Institutional Neurosis, John Wright \& Sons, Bristol, 1966.

Bavo, Psychiatrisch Centrum, St., De chronische patiënt, 2e Visie Rapport Visiecommissie, Noordwijkerhout, 1973.

Beers, J.H.A., Van, Wat is psychiatrische werpleging?, scriptie cursus ziekenhuisbeleid, 1972.

Bergen, B. van \& L. Hollands, Naar een profiel van de verpleegkundige, een gedragswetenschappelijke beschouwing over het beroep wan de verpleegkundige, De Tijdstroom, Lochem, $1978^{3}$.

Bergen, B. wan, L. Hollands, H. Nijhuis, De ontwikkeling van een kwaliteitsprofiel, een methode voor het beoordelen van verpleegkundig handelen, De Tijdstroom, Lochem, $1980^{2}$.

Bierenbroodspot, P., De therapeutische gemeenschap en het traditionele psychiatrische ziekenhuis, Boom, Meppel, 1976.

Bischoff, $\mathrm{Cl}$, Krankenpflege als Frauenberuf, in: Pflege und Medizin im Streit, Argument Verlag, Berlin, 1982.

Binnenkade, C., Honderd jaar opleiding tot verpleegkundigen in Nederland 1872 - 1973, Stafleu, Leiden, 1973.

Binneveld, H. \& R. Wolf, Een huis met vele woningen, 100 jaar katholieke psychiatrie Voorburg 1885 - 1985, Vught, 1985.

Blaauw, L. \& J. de Weger, 'Psychiatrisch verpleegkundige $66 \mathrm{k}$ bekwaam zonder verklaring', Tüdschrift voor Ziekenverpleging, 40, 1986, bli. 505 - 508 .

Bleeker, C., e.a., 'Chronische inrichtingspatiënten in de Bijlmer', Maandblad Geestelijke Volksgezondheid, 42, 1987, blz. 1331 - 1243.

Borgesius, E., J. De Lange, P. Meurs, Verpleegkundigen zonder uniform, over de pluriform miteit wan het beroep psychiatrisch verpleegkundige, De Tijdstroom, Lochem, 1988.

Bowling, T., 'The changing role of the psychiatric nurse', Nursing Mirror, 139, 1974, blz. $85-86$.

Bras, J., Tweespraak tussen residentiële andragogiek en psychiatrische verpleegkunde, De Tijdstroom, Lochem, 1977.

Bremer, J.J.C.B., De ziekenhuispatiënt, een hoofdstuk uit de medische psychologie, Dekker \& Van de Veght, Nijmegen, $1972^{2}$. 
Centralal Bureau voor de Statistiek, Maandbericht Gezondheidstatistiek, 1985/12.

Centralal Bureau voor de Statistiek. M/V Mannen en wrowwen naast elkaar, een overzicht van de statistische waameming wan mannen en wrouwen, Staatsuitgeverij, "s Gravenhage, 1987.

Cherniss, C., Staff bumout, job stress in the human senices, Sage Publications, Beverly Hills, etc. 1980.

Church, O.M., 'From custody to community in psychiatric nursing' Nursing Research, 36, 1987 , blz. $48-55$.

Ciompi, L., 'Ist die chronische Schizofrenie ein Artefact: Argumente und Gegegenargumente', Fortschr. Neurol. Psychiatr. Ihrer Grensgeb., 48, 1980, blz. $237 \cdot 248$.

Cohen Stuart, M.H., 'De differentiatie bij de verpleging van psychiatrische patienten', Het Ziekenhuiswezen, 38, 1965, blz. $204-210$.

Cohen Stuart, 'De differentiatie bij de verpleging van psychiatrische patiènten', Maandblad woor de Geestelijke Wolksgezondheid, 21, 1966, blz. 144 - 159.

Commissie Sociotherapie, Sociotherapie in de psychiatrische hulpverlening, Ministerie van Welzijn en Cultuur, Leidschendam, 1982.

Cosijns, H., 'De psychiatrisch verpleegkundige in de toekomst', Verpleegkundigen en Gemeenschapszorg, 2, 1982, blz. 93-101.

Dam, J., van., J. Lensen, T. de Vries, 'Werken er nog verpleegkundigen in de psychiatrie', Tijdschrift voor Ziekenverpleging, 41, 1987, blz. $230-234$.

Dane, $\mathrm{C}_{\text {, }}$ Geschiedenis van de ziekenverpleging, een kort overzicht ten dienste van de opleiding tot verplegende, De Tijdstroom, Lochem, 1968.

Darcy, P.T., 'Psychiatric Nursing today', Nursing Mirror, 147, 1978, no. 2 blz. 31 - 32; no. 3 , blz. $26-27$; no. 4 blz. $26-27$.

Dassen, Th., R. Halfens, R. Bambang Oetomo, H. Philipsen, 'Psychiatrisch verplegen mannen- of vrouwenberoep?", Verpleegkunde, 2, $1987 / 88 \mathrm{blz}, 90-100$.

Delimon, J.A.C., 'Sociowoningen: een verslag na twee jaar praktijkervaring', Tijdschrift voor Psychiatrie, 22, 1980 , blz. 696 - 709.

Dolan, $\mathbf{N}$., 'The relationship between burnout and job satisfaction in nurses' Joumal of Adwanced Nursing, 12, 1987, blz. 3 - 12.

Dörner, Kl., \& U. Plog, Irren ist menschlich, oder Lehrbuch der Psychiatrie / Psychotherapie, Psychiatrie Verlag, Wunstorf/Hannover, 1978.

Dröes, J.T.P.M., 'Beschut wonen, een intramurale beschermende woonvorm', Maandblad Geestelijke Volksgezondheid, 37, 1982, blz. 1174 - 1188 .

Eeden. Th., van, Rolopvattingen van en rolverwachtingen ten aanzien van B-verpleegkandigen, doctoraalscriptie, Rijksuniversiteit Leiden, 1982.

Esch. P., van der, 150 jaar staatstoezicht op het kramkzinmigenwezen, 's Gravenhage, 1975 deel I - III.

Esser, P.H., 'Acuut en chronisch in de psychiatrische inrichting', Maandblad voor de Geestelijke Volksgezondheid, 11, 1956, blz. 371 - 379.

Etzioni, A., The semi-professions and their organisation; teachers, nurses, social workers, Collier Macmillan, London, 1969.

Fox, B., B. van Herk, R. Esselink, R. Rijkschroeff, Psychiatrische tegenbeweging in Nederland, Van Gennep, Amsterdam, 1983.

Freudenberger, H.J., 'Staff burnout', Joumal of Social Issues, 30, 1974, blz. 159 - 165.

Freidson, E., De medische professie, De Tijdstroom, Lochem, 1981

Ganzevoort, J., 'Nieuwe taken voor psychiatrisch verpleegkundigen' Tijdschrift voor Ziekenverpleging, 26, 1973, bl2. $872-876$. 
Geneeskundige Hoofdinspektie voor de Volksgezondheid, Opleidingsieeplan B-verpleeg kundige, Leidschendam, 1983.

Gersons, B.P.R., 'De chronische patiènt", Maandblad woor de Geestelikt Wolksgezondheld, $39,1984$.

Giebing, H. e.a., 'De in-service opleidingen 1986; een samenvatting van de belangrijkste inhoudelijke wijzigingen", Tijdschrift woor Ziekenverpleging, 39, 1986, blz. $74-79$.

Gilel, R., 'Onze moeite met moeilijke mensen', Tijdschrift voor Psychiatrie, 26, 1984 , blz. $244-261$.

Ginkel, A.J.H. van., Demotivatie bij leraren, Swets en Zeitlinger, Lisse, 1987.

Goffman, E., Asylums; essays on the social situation of mental patients and other inmates, Anchor Books, New York, 1961.

Goldman, H.H., e.a., 'Defining and counting the chronically mentally ill', Hospital Community Psychiatry, 32, 1981, blz. 21 - 27.

Hackman, J.R. \& G.R. Oldham, 'Development of the Job Diagnostic Survey', Joumal of Applied Psychology, 60, 1975, blz. $159-170$.

Haen, F. de, \& E. Schretlen, In plaats van een bed, Nationaal Centrum voor de Geestelijke Volksgezondheid, Utrecht, 1981.

Haveman, M.J., 'De-institutionalisering van de intramurale psychiatrische zorg', Tijdschrift voor Sociale Gezondheidszorg, 62, 1984, blz. 698 - 706.

Haveman, M.J., Van klinisch verblijf naar wervangende zong; een onderzoek naar ontslagbelemmerende factoren bij lang opgenomen patiënten in psychiatrische ziekenhuizen, Proefschrift, Rijksuniversiteit Limburg, Maastricht, 1987.

Hermans, H., Doelstellingen achter verpleegkundig handelen in een psychiatrische instelling, doctoraalscriptie, Rijksuniversiteit Limburg, Maastricht, 1988.

Hey, W., de., De H.B.O.V in ontwikkeling, in: Bergen B, Van, \& L. Hollands (red.), Over de verpleging; bijdrage ter ondersteuning van de verpleegkundige praktijk, De Tijdstroom, Lochem, 1979.

Hofstede, G., 'Werken aan de organisatiecultuur', Bedrijfskunde, 58, 1986, blz. 102 - 106.

Holman, B., Niet behandelen, maar onderhandelen; over een nieuwe begeleidingsmethodiek in de beschermende woonvormen, Studiedag over het begeleiden in de verblijfspsychiatrie en de beschermende woonvormen, Stichting Centrum St.Bavo, Noordwijkerhout, 1984.

Holman, B., Oude beroepen in een nieuw werkveld; over de contouren van een wereniging van werkers in de verblijfspsychiatrie en/of beschemende woonvormen, Lezing gehouden. bij de oprichting van de vereniging, november 1985 .

Holman, B., \& J. Wennink, "De hospitalisatiethese: een dubieuze these", Tijdschrift voor Psychiatrie, 27, 1985, blz. 83 - 93.

Holman, B., \& $J$. Wennink, 'Emancipatie van de chronische psychiatrische patient' Tijdschrift voor Ziekenwerpleging, 39, 1986, blz. $68-73$.

Holman, B., De beschut wonen begeleider; een onderzoek waar de motwatie en de manier van werken van begeleiders in een beschutte woonvorm in het algemeen psychiatrisch ziekerhuis., Stichting Centrum St.Bavo, Noordwijkerhout, 1986.

Hoop, W. van der., 'Hoe leerling verpleegkundigen in een psychiatrisch ziekenhuis over hun patiënten en over hun eigen taak denken", Sociologische Gidss, 20, 1973, blz. $30-47$.

Hopman, W.M., Naar een wetenschappelijke verpleegkunde; bijdrage tot de venwetenschappelijking van het werplegen, Stafleu, Alphen a/d Rijn, 1980.

Hout, A.C. van den, Ontsiagen psychiatrische patiënten. een longitudinaal onderzaek naar heropname, Katholieke Universiteit Nijmegen, 1985. 
Houtepen, R., 'Grenzen wan methodisch werken in de werpleegkunde, een kritiek op wijsgerige grondslag' Metamedica, $65,1986, \mathrm{blz}, 7-20$.

Jacobs, $\mathrm{D}_{*}$ De verpleging in het psychiatrisch centrum, De Tijdstroom, Lochem, 1968.

Jong, J.H.J. de, (red.) 'Beroepsprofiel' de basis woor werplegen en professionaliseren, symposiumverslag. De Zuysel, Deventer, 1982.

Jong, A. de, Over psychiatrische invaliditeit, Rijksuniwersiteit Groningen, 1984.

Keane, M.P., "The nursing process in psychiatry", Nursing Times, 17, 1981, blz. $1273-1275$.

Kerstens, J., 'Beroepsprofiel van de psychiatrisch werpleegkundige.' I, Onderwijs en Gezondheidszorg, 7, 1983, blz. 156-161.

Keirse, $\mathrm{M}_{\text {, }}$ 'Burn-out bij gezondheidswerkers, deel I externe factoren', Tijdschrift voor Ziekenverpleging, 41, 1987, blz 13 - 22. (a)

Keirse, M., 'Burn-out bij gezondheidswerkers, deel II zelf burn-out voorkomen', Tijdschrift voor Ziekenverpleging, 41, 1987, bli 47 - 53. (b)

Kramer, $F_{\text {, }}$ Gesichiedenis van de zorg voor geesteszieken, De Tijdstroom, Lochem, 1969.

Kramer,F., Psychiatrische verpleegkunde, De Tijdstroom, Lochem, 1970-2.

Kuiper, P.C., Hoofdsom der Psychiatrie, Bijleweld, Utrecht, $1975^{3}$.

Laarse - de Bruin, A, van der, Veranderingev in de krankziwnigenverpleging van 1880 - 1970, doctoraalscriptie, Katholieke Hogeschool Tilburg, 1981.

Lamb, H.R., 'Staff burnout in work with long-term patients', Hospital community psychiatry, 30,1979 , blz. $396-398$.

Lange, J. de. \& E. Borgesius, 'Even overdragen', een beeld van de verpleegkundige in de psychiatrie, De Tijdstroom, Lochem, 1988.

Leerstof Ziekenverpleging B. deel I. Staatsuitgeverij, 's Gravenhage, 1974.

Lutters, Th.G. \& W.C.M. Smits, Het psychiatrisch ziekenhuis, Agon, Elsevier, 1968.

Maslach, Chr., "The client role in staff burn-out', Journal of Social Issues, 34, 1978, blz. $111-124$.

Maslach, Chr. \& S.E. Jackson, 'The measurement of experienced burnout', Journal of Occupational Behaviour, vol. 2, 1981, blz. $99-113$.

Maslach, Chr., \& S.E. Jackson, "Burnout in thealth professions: a social psychological analysis, in: Sanders, G.S. \& J. Suls, Social psychology of health and ilhess, Lawrence Erlbaum Associates, New York, 1982.

Maslach, Chr., Understanding burnout, definitional issues in analyzing a complex phenomenon, in: Paine, W.S., Job stress and bumout, research, theory and intenention perspectives, Sage Publications, Beverly Hills, etc. 1982.

Mertens, P., Sociotherapie, een verpleegkundig behandelingsmodel?, De Tijdstroom, Lochem, 1985.

Meij-de Leur, A.P.M., van der, Van olie en wijn, geschiedenis van verpleegkunde, geneesikunde en sociale zong, Agon Elsevier, Amsterdam, 1974?

Meyboom, F., 'De taak van de verplegenden in een psychiatrische inrichting', Maandblad voor de Geestelijke Volksgezondheid, 7, 1952, blz. 25 - 29.

Mintzberg, H., The nature of managerial work, Harper \& Row, New York, 1973.

Mintzberg, H., Structure in fives, Prentice-Hall, Englewood Cliffs, New Jersey, 1983.

Mok, A.L., Beroepen in actie "Boom, Meppel, 1973.

Nationale Raad voor de Volksgezondheid, Rapport in het kader wan de specialisaties in de verpleegkunde betreffende "De verpleegkundige belost met speciffeke taken in de geestelijke gezondheidszorg, met name in de psychiatrische hulpverlening", Rijswijk, 1983.

Nationaal Ziekenhuis Instituut, Statistiek personeelsterkte resp. $1977 \mathrm{t} / \mathrm{m} 1987$ Utrecht, resp. $1978 \mathrm{t} / \mathrm{m} 1988$. 
Nationaal Ziekenhuis Instituut., De inmwurale gezondheidszong in ciffers per 1 januari 1987, rapport nr. 88.549, Utrecht, 1988.

Nationaal centrum voor de Geestelijke volksgezondheid, Gids geestelikke Gezondheidszong 1986 - 1987, Van Loghum Slaterus, Deventer, 1987.

Nationaal centrum voor de Geestelijke volksgezondheid, G.G.Z. in getollew $1985, \mathrm{E}$. Ketting, e.a., Utrecht, 1987.

Nederhof, A.J., Beter onderzoek, bestrijding wan foutenbronnen in sociaal-weterschappelijk onderzoek, Vuga, Den Haag, 1981.

Offerhaus, Wachten op oneindig, de chronische pateënt in de psychiatrische invichting, Lochem Slaterus, Deventer, 1983.

Ommen, M. Van, Tussen professionele cutonomie en wederzijdse aanpassing, Academisch proefschrift, Rijksuniversiteit Groningen, 1988.

Peeters, H,F.M. \& C.P. de Vos, Een historische analyse van een provinciad psychiatrisch centrum over de periode 1885 - 1977, in: Binneveld, II.M.W. e.a., Een psychiatrisch verleden, uit de geschiedenis van de psychiatrie, Ambo, Baarn, 1982.

Peeters, A., Werkzaamheden wan psychiatrisch verpleegkandigen, doctoraalscriptie Rijksuniversiteit Limburg, Maastricht, 1988.

Peplau, H., 'Psychiatric nursing; role of nurses and psychiatric nurses', International Nursing Review, 25, 1978, blz, 41 - 47.

Philipsen, H., Gezondheidszorg als project en bejegening, waarden ten aanzien van ziekte, gezondheid en samenleving, Rijksuniversiteit Limburg, Maastricht, 1988.

Poot, A., '75 jaar B-verpleegkundige, episoden uit de Valeriuskliniek te Amsterdam' Maandblad Geestelijke Volksgezondheid, 40, 1985, blz. 1297 - 1313.

Ree F. van., 'De B-verpleegkundige als behandelaar?', Maandblad Geestelijke Volksgezondheid, 30, 1975, blz. 391 - 396.

Rozendal, H., 'Van broeder tot sociotherapeut: ontwikkelingen in en rond de verpleegkunde', Tijdschrift woor Psychiatrie, 23, 1981, blz. $307-316$.

Schaft, A.J. van der, Methodisch verplegen in de psychiatrie, doctoraaliscriptie Rijksuniversiteit Limburg, Maastricht, 1987.

Scheer, W.M., van der, "Vooruitgang in de krankzinnigenverpleging $1850-1928$ " Het Ziekenhuiswezen, 1928, blz. 188 - 196.

Schuring, G., L.E. Liem, B.J. Roosenboom, Behandelmodulen; handleiding woor gebruik in psychiatrische ziekenhwizen, N.Z.I., Utrecht, 1984, deel I en deel II.

Schut, J., Van dollwuys tot psychiatrisch centrum, ontwikkeling en furktie, De Toorts, Haarlem, 1970.

Smits, W.C.M., "Veranderingen in de taak van de verpleger in een psychiatrisch ziekenhuis', Tijdschrift voor Ziekenverpleging, 24, 1971, blz. $416-423$.

Spijker, $T$., Mooi en beschaafd verplegen, en historische analyse van een vrouwenberoep, De Tijdstroom, Lochem, 1979.

Spradley, J.P., Participant observation, Holt Rinehart and Winston, New York, 1980.

Stockwell, T., The nursing process in psychiatric nursing, Croom Helm, London, 1985.

Stolte, J.B., Zieken en hun verzongers; de mensen in de gezondheidszorg, De Tijdstroom, Lochem, $1981^{2}$.

Thiadens, A.J.H. \& M.J. Smulders-Aghina, De verpleegkundige die ons toe-komt, Van Loghum Slaterus, Deventer, 1971.

Thierry, H., \& A.M. Koopman-Iwema, Motivatie en satisfactie, in: Drenth, P.J.D., e.a. (red.), Handboek arbeids-en onganisatiepsychologie, Van Loghum Slaterus, Deventer, 1984, I. 
Vermaak, $\mathrm{H}_{\text {s, }}$ Een psychiatrisch verpleegkundig beroep - of niet? Tijdschrift woor Ziekenverplegüng, 27,1974 , blz. 728 - 735 .

Vermaas, H., 'Psychiatrische verpleegkunde - heeft dit vakgebied nog levensvatbaarheid?', Tijdschrift voor Ziekenverpleging; 33, 1980, blz. 1027 - 1040.

Verwey, J.A., Verpleging in beweging; de stabiliteit in de personele bezetting van verpleegafdelingen in algememe ziekenhuizen en de opleidingen tot verpleegkundige,

De Tijdstroom, Lochem, 1981.

Vijselaar, J., Krankzinnigengesticht; psychiatrische unrichtingen in Nederland $1880-1910$, Fibula-Wan Dishoek, Haarlem, 1982.

Vries-Griever, A.H.G., de, e.đ, Techwiek en patiẻntenzorg; een arbeidspsychologische studie naar de invloed wan nieuwe technologien op de inwloed van het verpleegkandig werk in ziekenhuizen, Rijksuniwersiteit Groningen, 1987.

Ward, F., Het verpleegkandig proces in de geestelijke gezondheudrzorg, Intro, Nijkerk, 1987.

Weisglas, M., De overgang van oppassers en oppasseressen naar verplegers en verpleegsters in de krankzinnigengestichten 1880 - 1921, doctoraalscriptie, Amsterdam, 1981.

Wennink, J., Het beschut wonen effect; de effectiviteit wan beschut wonen in het Algemeen Psychiatrisch Ziekenhuis, Stichting Centrum St. Bavo, Noordwijkerhout, 1986.

Windt, W. van der., Werken in de intramurale gezondheidszorg; een arbeidsmarktverkenning verpleging en verzorging (1983 - 1992), Nationaal Ziekenhuis Instituut, Utrecht, 1988.

Wing, J.K. \& G.W. Brown, Institutionalism and Schizophrenia, Cambridge University Press, Cambridge, 1970.

Wing, J.K., 'Who becomes chronic?' Psychiatric Quarterly, 50, 1978, blz. 178.

Wing, J.K. \& B. Morris (ed), Handbook of psychiatric rehabilitation practice, Oxford University Press, Oxford, 1981.

Wit, L.J.M. de., 'Agogische aspecten betreffende de omgang van de verpleegkundige met de psychiatrische patient', Tijdschrift voor Ziekenverpleging, 28, 1975, blz. 788 - 792 .

Wollants, G., 'Van stress tot burn-out', Psychiatrie en verpleging, 63, 1987, blz. 168 - 174.

Wondrak, R., 'It's a mystery... the role of the psychiatric nurse', Nursing Mirror, 154, 1982, blz. $18-19$.

Yura, H, \& M.B. Walsh, The nursing process; assessing, planning, implementing, evaluating, Appleton-Century-Crofts, New York, $1978^{3}$. 
BIJLAGE 


\section{Bijlage A INTERVIEWS}

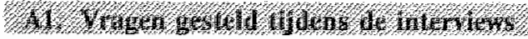

1. Beschrijt eens een werkdag.

2. Hoe is de taakalbakening to.w andere disciplines?

3. Wat is ww positie als psychiatrisch werpleegkondige in de instelling?

4. Hebt ta zelf iets gemerkt wan weranderingen in de psychiatrische verpleging?

5. Terugkomend bij de patienten, wat zijn dat eigenlijk voor mensen?

6. Ower welke vaardigheden noet u beschikken om uw werk te doen?

7. Hoe, en waar hebt a deze geleerd?

8. Is een opleiding tot verpleegkundige woonwaarde om het werk op een longstay afdeling te kunnen doen?

9. Wut is thet werschill tussen psychiatrische werpleging en andere vormen van verpleging?

10. Wat is thet verschil tussen verplegen op een longstay afdeling en een acute (opname) afdeling?

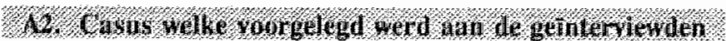

Dhr. P. ( 47 jaar, leraar Nederlands) verblijft sinds 1978 in een psychiatrische instelling, op verschillende afdelingen.

Verslagy wan de opname afdeling: (april 1979)

- Vorige opname - zes maanden geleden - wegens depressief toestandsbeeld.

Na twee weken begon dhr. P. allerllei aktiviteiten binnen de instelling te ontplooien. Was o.a. aktief in de bibliotheek.

Ontslag na twee maanden. Na een maand weer opgenomen met dezelfde klachten.

Ook nu herstelde hij weer snel. Organiseerde de Kerstviering woor de afdeling. Was druk in de bibliotheek.

Inmiddels derde opname. Zelfoe beeld.

Echtgenote is met maatschappelijk werk gaan praten over echtscheiding. Kinderen willen niet meer op bezoek komen.

Verslag huidige afdeling: (mei 1986)

Dhr. P. is cen rustige, doch aktieve man. hij is lid van diverse kommissies bimen de instelling. Werkt halve dagen in de bibliotheek. Organiseerde uitstapjes voor de afdeling.

Krijgt zelden bezoek van familie, alleen zijn kinderen komen wel eens. Zelf bezoekt hij geen fanilice of kennissen.

Dragat nog steeds dezelfde kleren sinds zijn eerste opname. Hij is er niet toe te bewegen om mee natar de stad te gaan om nieuwe te kopen.

Wil niet overgeplaatst worden naar de sociowoningen.

Vrägen bij de casus

Wat is de taak van de verpleegkundige ten aanzien van dhr. P.?

Wat is de taak wan andere disciplines in deze situatie?

Waatin verschilt de verpleegkundige taak wan die van anderen?

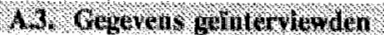

Een aantal algemene kenmerken wan de geïnterviewden zal hier weergegeven worden. Het gaat daarbij alleen on thet geven van een indruk van de respondenten, teneinde te kunnen bepallen of aan de doelstelling, zoveel mogelijk spreiding, voldaan is. 


\section{Aantal per instelling}

In totaal zijn 52 verpleegkundigen ondervraagd. Het aantall per instelling is bepaald atn do hand van het totale aantal patiënten per instelling. Gegevens over de grootte van de sector longstay zün pas achteraf verkregen.

Onderstaand schema geeft een overzicht van het aantal geïnterviewden per instelling. De totaalper. centages zijn bepaald op basis van gegevens over alle verpleegkundigen, werkzann in de longstayklusters van de vijf deelnemende instellingen. $(n=438)$

instelling deelnemers total in longstay werkzam

$\begin{array}{lcc}\text { I. } & 11 & 76 \\ \text { II. } & 10 & 86 \\ \text { III. } & 13 & 171 \\ \text { IV. } & 10 & 53 \\ \text { V. } & 8 & 52 \\ & \ldots-. & 538\end{array}$

\section{Geslacht en leeftijd}

De mannen zijn oververtegenwoordigd, zoals uit onderstaand schema blijki,

\begin{tabular}{|c|c|c|c|c|}
\hline & aan & & leeftijd & totaal in longstay werkzaam \\
\hline $\operatorname{man}$ & 36 & $(70 \%)$ & gem. 35 jaar & 53 \\
\hline vrouw & 16 & $(30 \%)$ & gem. 32 jaar & 47 \\
\hline totaal & 52 & & gem. 34 jaar & \\
\hline
\end{tabular}

\section{Funktie}

Leidinggevenden zijn eveneens oververtegenwoordigd:

$\begin{array}{llc} & \text { aantal } & \text { totaal in longstay werkzaam } \\ \text { leidinggevend } & 32(62,5 \%) & 26 \\ \text { niet-leidinggevend } & 20(38.5 \%) & 74\end{array}$

\section{Opleiding}

Op twee na hadden alle respondenten een B-opleiding. De twee zonder B-opleiding hadden de H.B.O.V. opleiding gevolgd.

Naast de B-opleiding hadden 11 respondenten ook een A-opleiding. De kaderopleiding was door 18 respondenten gevolgd. De helft, 26 verpleegkundigen beschikte nog over een andere opleiding, zoals bijvoorbeeld I.W. of interne bijscholingen.

\section{Evaring}

Het aankal jaren ervaring in de longstay variecrde van korter dan fen jaar lo! 23 jaar.

$\begin{array}{lrc}\text { korter dan een jaar ervaring } & 6 & (12 \%) \\ 1 \text { jaar }>\text { ervaring }<6 \text { jaar } & 22 & (42 \%) \\ 6 \text { jaar }>\text { ervaring }<11 \text { jaar } & 20 & (38 \%) \\ 11 \text { jaar }>\text { ervaring } t / \mathrm{m} 23 & 4 & (8 \%)\end{array}$




\section{Billage B SCHALEN}

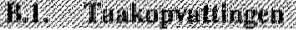

De gebruikte antwoordschaal was een wijfpunt Likertschaaltype lopend van 'nooit' tot 'erg wak' Per vraag zijn twee metingen verricht. Resp. naar de mate waarin de aktiviteit woorkomt en naar de wenselijkheid wan de frekwentie.

\section{Persoramilike zong}

1. Hoe vaak ziet u crop toe dat patiènten tijdug op hun werk / aktiviteïten verschijnen?

2. Hoe vaak begeleidt u patienten bij het wakker worden en/of opstan?

3. Hoe vaak ziet u erop toe dat patiênten niet al te vroeg gaan slapen?

4. Hoe vaak geeft $\mathrm{u}$ begeleiding bij het bereiden van de broodmaaltijd?

5. Hoe valak helpt u patiènten bij het op-en afruimen van de tafel voor de maaltijd?

6. Hoe vaak geeft u begeleiding bij de afwas?

7. Hoe valak begeleidt u patienten bij het wassen en ankleden?

8. Hoe vaak begeleidt u palienten bij het baden of douchen?

9. Hoe vaak begeleidt u patięnten naă de afgesproken aktiviteiten?

10. Hoe vaak begeleidt u patiêntes bij het verschonen en opmaken van de bedden?

11 Hos vaak bepaalt $u$ als hulpwerlener welke kleding de patiënt draagt?

\section{Begeletiding huishouden}

1. Hoc waak begelleidt u paliënten bij het onderhouden van do gemeenschappelijke ruimten?

2. Hoe vaak begeleidt u patiënten bij het onderhouden van hun kamers?

3. Hoe waak begeleidt u patiènten bij het werzorgen (wassen e.d.) van hun kleding?

4. Hoe vaak geeft u begeleiding bij het kopen van levensmiddelen voor de maaltijden?

\section{Gezamenlijke aktiviteiten}

1. Hoe vaak wandelt $\mathrm{u}$ met patiënten?

2. Hoe vaak speelt u gezelschapsspelletjes met patiënten?

3. Hoe vaak gaat u met patiènten naar de stad /het dorp?

4. Hoe vaak begeleidt u patiënten bij het doen yan boodschappen voor persoonlijk gebruikt?

\section{Begeleidende gesprekken}

1. Hoe valak probeert u met patienten te praten, omdat $u$ gemerkt heeft dat er wat met hen is?

2. Hoe walk praat u met patiönten over hun wensen?

3. Hoc waak legt u patienten uit wat het belang is van de aktiviteiten, warmee ze hun dagen en thachten villen?

4. Hoc vaalk pratat u met patięntem over hun gewoelens en emoties?

5. Hoe vaak praat u met patienten over de door hen te ondernemen aktiviteiten?

6. Hoe vaak pratat u met patienten over spanning en moeilijkheden, die hun oorsprong vinden in het groepsgebeuren op de aldeling?

7. Hoe vaak heeft u een vertrouwelijk gesprek met de patiënten"?

8. Ho valk stimuleert a patienten om over persoonlijke problemen te praten?

9. Hoe vaak vaagg u de patiënten wat ze van ten bepaalde vorm van daginwulling vinden?

\section{Informatie \& kobrdinatie}

1. Hoe vaak legt u contacten met andere disciplines voor patiënten?

2. Hoc vaak koördineert u de zorgverlening voor de patiënt?

3. Hoe valk onderhoudt u kontakten met familieleden / kennissen van de patiënten?

4. Hoe valk heeft u gesprekken met familieleden van patiëmten?

5. Hoe vaak informeert u familie van patiënten over de stand van zaken met betrekking tot de patiënt?

6. Hoe vaak legt w kontakten met externe instanties/disciplines voor patiènten? 


\section{B2. Choniciteli thes scianal}

Antwoordschaal:

helemaal eens / eens / weet niet / oneens / helemaal oneens

\section{Ziektethese}

1. Chronische psychiatrische patiënten worden in hun normaal funktioneren belemmerd door een ziekte.

2. Chronische psychiatrische patiënten zijn zieke mensen.

3. Hun ziektebeeld is niet inpasbaar in een normale gezinssituatie.

4. Het zijn mensen die dusdanig ziek zijn dat ze niet in de maatschappij kunnen funktioneren.

5. De meesten vertonen duidelijk psychiatrisch gedrag.

6. Het zijn vooral (chronisch-) psychotische mensen.

\section{Hospitalisatiethese}

1. Het gedrag van chronische patiënten heeft vooral te maken met hun langdurige opname in de inrichting.

2. De hospitalisatie-effekten zijn de oorzak van het feit dat ze nu nog in de psychiatrie verblijven.

3. Niet hun ziekte, maar de psychiatrie is schuld aan het gedrag van chronische psychiatrische patiënten.

4. Ze zijn verleerd om eigen initiatieven te nemen.

5. Het zijn gewone mensen die gehospitaliseerd zijn geraakt.

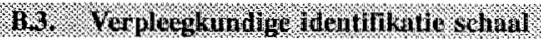

\section{Antwoordschaal:}

helemaal eens / eens / weet niet / oneens / helemaal oneens

\section{Identifikatie met verplegen}

1. Het hebben van een verpleegkundige opleiding is een voorwaarde om dit werk te kunnen doen.

2. Je moet verpleegkundige zijn om dit werk te kunnen doen.

3. Je moet verpleegkundige zijn vanwege de vakkenmis dic nodig is om met mensen om te gaan in de psychiatrie.

4. Om dit werk te doen hoef je geen verplecgkundige te zjjn, het heeft met je persoonlijkheid te maken.

5. met alleen een opleiding inrichtingswerk kun je dit werk net zo goed doem.

6. In dit werk is het nodig dat je verpleegkundige bent, om begeleiding op sociaal vlak te kunnen geven.

7. Mijn werk als psychiatrisch verpleegkundige is geen verplegen.

\section{Identifikatie met therapeuten}

1. Mijn werk heeft veel overeenkomst met het werk van een psycholoog.

2. Mijn werk heeft veel overeenkomst met het werk van een psychiater.

3. Mijn werk heeft veel overeenkomst met het werk van ecn maatschappelijk werker.

4. Mijn werk heeft veel overeenkomst met hel werk van een ergotherapeut.

5. Ik ben een soort co-therapeut (van de beharidelaar).

6. Als psychiatrisch verpleegkundige ben ik meer therapeutiseh dan verpleegkundig bezig. 


\section{Restgroep}

1. De verpleegkundige basis is nodig on dit werk te kunnen doen.

2. Je doet de patiënten tekort als er geen verpleegkundigen op de afdelingen werken.

3. Dit werk zou goed door wrijwilligers (zonder specifieke opleiding) gedaan kunnen worden, als te mar voldoende levenservaring likebben.

4. Een ervaren huismoeder zou dit werk ook kunnen doen.

5. Mijn werk heeft veel overeenkomst met het werk wan een A-verpleeghundige.

6. Mijn werk heeft veel overecenkomst met het werk wan een $Z$-verpleegkundige.

\section{B.}

M.B.I.-scalle; copyright by Maslach Jackson. Translated with permission of the author by Th. Dassen, State University of Limburg, Maastricht.

De antwoordschaal bestaat uit twee metingen; cén naar de frekwentie en éen naar de intensiteit van het betreffende gevoel. Voor de samenstelling wan de subschaten is gebruik van de indeling wit het oorspronkelijke instrument.

Hoe wak komt dil voor?

nooit / zelden / soms / vaak / erg vaak.

Wanneer dit woorkomt, hoe intens is dat dan?

n.w.t. / erg zwak / zwak / matig / sterk / erg sterk

\section{Emotionele uitputting}

1. Ik woel me mentaal uitgeput door mijn werk.

2. Ik voel me uitgeput aan het einde van een werkdag.

3. Ik voel me vermoeid wanneer ik 's ochtends opsta en weet dat ik die dag moet gaan werken.

4. De hele dag met mensen werken vergt het uiterste van mij.

5. $\quad$ Ik voel me 'opgebrand' door mijn werk.

6. Ik woel dat ik te hard werk in mijn baan.

7. Het werken met mensen roept bij mij spanningen op.

8. Ik heb het gevoell dat ik niet verder kan.

9. Ik voel me gefrustreerd door mijn werk.

\section{Persoonlijke voldoening}

1. $\quad \mathrm{k}$ kan me gemakkelijk inleven in de gevoelens văn de patiënten.

2. Ik weet de problemen van mijn patienten adekwat op te lossen.

3. Ik voel dat ik door mijn werk mensen positief $k a n$ beïnvloeden.

4. Ilk voel dat ik veel energie heb.

5. Ik kan gemakkelijk een ontspannen sfeer scheppen op de afdeling.

6. Het werken met patiënten vrolijkt mij op.

7. Ik beb waardevolle dingen in dit werk geleerd.

8. Tijdetus mijn werk ga ik met problemen op een rustige manier om.

\section{Depersonalisatie}

1. Ik heb het gevoel dat ik patiënten onpersoonlijk behandel.

2. $\quad \mathrm{k}$ heb het gevoel dat mensen mij koud laten.

3. I ben er ongerust over dat dit werk me in de omgang met mensen gehard heeft.

4. Ik woel dat patiënten mij soms hun problemen werwijten.

5. Ik woel me niet op mijn gemak over de wijze waarop ik met patiênten omga. 


\section{Bijlage C. FAKTORTABEL AKTIVITEITEN}

\section{reitelith}

Persoonlijke zorg

1. Toexien dat pat. naar. akt. gaan

F1 $\quad F 2$

83

F4

F5

2. Begl wakker worden en opstaan

$\begin{array}{lllll}.49 & .39 & .11 & .24 & .19 \\ .77 & .05 & .03 & .05 & .10 \\ .64 & .20 & .03 & .24 & .17 \\ .48 & .14 & .09 & .32 & .36 \\ .63 & .09 & .04 & .22 & .14 \\ .63 & .06 & -.02 & .21 & .38 \\ .83 & -.15 & .08 & .09 & -.10 \\ .82 & -.11 & .08 & .18 & -.01 \\ .64 & .16 & .10 & .46 & -.03 \\ .62 & -.21 & .12 & .05 & -.04\end{array}$

3. Toezien niet te vroeg gaan slapen

4. Begeleiden bij broodmaaltijden

5. Helpen op/afruimen tafel

6 . begeleiden bij afwas

7 . Begeleiden wassen en aankleden

8. Begeleiden baden en donchen

9. Begeleiden pat. naar aktiviteiten

10. Begeleiden opmaken en verschonen bedden

Begeleidende gesprekken

1. Praten met pat. omdat er iets is

2. Praten over wensen van patiënten

3. Belang aktiviteiten uitleggen

4. Praten over gevoelens en emoties

5. Praten over door pat.te ondern. akt.

6. Praten over spanningen en moeilijkheden

7. Vertrouwelijk gesprek met patienten

9. Informeren naar daginvulling

\section{Informeren en koürdineren}

1. Kontakten andere disciplines

2. Zorgyerl. Koörd. voor patiënten

3. Kontakten familieleden

4. Gesprekken met familie

5. Familie informeren over patiènt

6. Kontakten externe instanties/disciplines

$\begin{array}{rrrrr}-.01 & .26 & .59 & -.04 & .18 \\ .03 & .17 & .61 & -.09 & .13 \\ .21 & .10 & .79 & .18 & -.01 \\ .21 & .09 & .77 & .23 & -.10 \\ .24 & .13 & .73 & .17 & -.05 \\ -.15 & .08 & .67 & -.09 & .10\end{array}$

\section{Gezamenlijke aktiviteiten}

1. Wandelen met patiènten

2. Gezelschapsspelletjes met patiënten

3. Met pat. naar stad of dorp gaan

4. Boodschappen voor privê gebruik

\section{Begeleiding huishouden}

1. Begeleiden onderthoud gemeensch. ruimten

$\begin{array}{rrrrr}.21 & .22 & -.01 & .19 & .59 \\ .36 & .22 & .16 & .08 & .68 \\ .27 & .21 & -.04 & .11 & .63 \\ -.16 & -.01 & .20 & .21 & \mathbf{5 6} \\ 8.9 & 4.7 & 2.6 & 1.6 & 1.4 \\ 26 & 14 & 8 & 5 & 4\end{array}$

eigemwaarde

percentage verklaarde wariantie

(varimax rotatie) 
Persoonlifke zorg

1. Toezien dat pat. naar. akt. gaan

2. Beglwakker worden en opstaan

3. Toezien nilet te vroeg gaan slapen

4. Begeleiden bij broodmaaltijden

5. Helpen op/afruimen tafel

6. begeleiden bij alfwas

7. Begeleiden wassen en aankleden

8. Begeleader baden en donchen

9. Begeleiden pat. naar alktiwiteiten

10. Begeleiden opnaken en werschonen bedden

$\begin{array}{rrrrr}\text { F1 } & \text { F2 } & \text { F3 } & \text { F4 } & \text { F5 } \\ .63 & .25 & .11 & .21 & -.13 \\ .79 & .03 & -.01 & .06 & .06 \\ .68 & .17 & .05 & .22 & .11 \\ .50 & .16 & .03 & .44 & .21 \\ .61 & .08 & .08 & .20 & .05 \\ .64 & .05 & .04 & .38 & .13 \\ .83 & -.02 & .01 & -.05 & .21 \\ .81 & .03 & .03 & .02 & .25 \\ .62 & .16 & .10 & .13 & .26 \\ \mathbf{5 8} & -.07 & .14 & . .01 & .01\end{array}$

Begeleidende gesprekken

1. Praten met pat. omdat er iets is

2. Praten over wensem van patiènten

3. Belang aktiviteiten uitleggen

4. Praten over gewoelens en emoties

5. Praten over door patte ondern. akt.

6. Praten over spanningen en moeilijkheden

7. Vertrouwelijk gesprek met patienten

8. Pat. stimul. over pers. probl, te praten

9. Informeren naar daginvulling

$\begin{array}{rrrrr}.14 & .72 & .11 & -.01 & .16 \\ .07 & .75 & .06 & .06 & .11 \\ .20 & .64 & .12 & .23 & .18 \\ .03 & .80 & .09 & .00 & .15 \\ .14 & .73 & .15 & .25 & .03 \\ .02 & .66 & .14 & .27 & .09 \\ . .01 & .80 & .09 & .00 & .15 \\ .03 & .74 & .10 & .03 & .11 \\ .06 & .61 & .19 & .26 & .06\end{array}$

Infomeren en koördineren

1. Kontakten andere disciplines

2. Zorgverl. Koörd. voor patiënten

3. Kontakten familieleden

4. Gesprekken met familie

5. Familie informeren over patiènt

6. Kontakten externe instanties/disciplines

$.03 \quad .25$

.09

.13

.13

.17

$-.02$

Begeieiding huishouden

1. Begeleiden onderhoud gemeensch, ruimten

2. Begeleiden onderhoud kamers

3. Begeleiden verzorgen en wassen kleding

4. Kopen levensmiddelen voor maaltijdem.

\section{Gezamenlijke aktiviteinen}

1. Waridelen met patiènten

2. Gezelschapsspelletjes met patiennten

3. Met pat. naar stad of dorp gaan

4. Boodschappen voor prive gebrük

.42

.30

.31

.37

.29

$$
.37
$$

.23

.07

$-.05$

.05

.62

eigenwaarde

percentage verklaarde variantie

(varimax rotatic)

$\begin{array}{ccccc}10 . & 4.3 & 2.3 & 1.6 & 1.4 \\ 30 & 13 & 7 & 5 & 4\end{array}$




\section{SUMMARY}

This book reports a study of the tasks of psychiatric nurses. On the basis of a review of the literature it became clear that these tasks are determined by the functions of the psychiatric hospitals. An important development in the psychiatric hospitals is the change in the way that chronic patients are cared for. Considering the notion that institutionalization contributes to the chronicity of psychiatric illness, the emphasis in care is put more and more on the stimulation of the independence of the patients. Psychiatric nurses are expected to change their traditional nursing roles to that of therapist. As a consequence of this development in mental health care, changes have occurred in the tasks of psychiatric nurses. These changes in psychiatric hospitals and in the tasks of the psychiatric nurse have resulted in a type of identity crisis for psychiatric nurses.

The study examined the question of whether a relationship exists between the task perceptions of psychiatric nurses and the following variables:

- their view of the problems of chronic patients;

- their identification with the nursing profession;

- burnout;

- and several personal characteristics.

Furthermore the study determinated:

- whether differences in task perceptions exist between nurses who work or do not work with chronic psychiatric patients;

- whether differences in task perceptions are connected with the psychiatric hospital in which they work.

The study, in which nurses of ten psychiatric hospitals participated, consisted of the use of interviews and a questionnaire. Interviews were conducted with 52 nurses from 5 different psychiatric hospitals. The data obtained from the interviews were used to compile a questionnaire. This questionnaire was presented to \pm 1150 nurses from 6 psychiatric hospitals. The response was $78 \%$, which amounts to almost 900 participants in the final study.

From the study findings it appears that psychiatric nurses want to reduce their activities in the daily care for the patient and increase their patient teaching activities. This is the case for nurses working on long-term units as well as for nurses working on short-term units.

Nurses working on long-term units spend most of their time in the personal care of the patients. On the short-term units most of the nurses' time is devoted to contacts with colleagues and/or other disciplines. On both the long- and short- 
term units the least amount of nursing time was given to guiding patients in housekeeping. In general, the nurses reported spending most of their time in patient teaching activities.

By using factor-analysis a classification was made in three task dimensions. This classification of activities consists of:

- patient care;

- pattent teaching activities;

- coordinating and consulting activities.

Patient care includes guidance in daily personal care and supervision and guidance in housekeeping. Patient teaching activities consist of providing instructions in the psychosocial area and activities undertaken together with the patients. Consultative activities include staff meetings of the nurses with relatives of patients and with other disciplines.

In this regard it is important to make a comparison between this classification of tasks derived from empirical data and a classification derived from the literature. Both in this study and in the literature the common categories are 'activities directed towards daily care' and 'patient teaching'.

An instrument which distinguishes two kinds of causes of chronicity: psychiatric impairments or dysfunctions as symptoms of a disease and personal reactions to impairments (institutionalism), was administered to psychiatric nurses to determine their views of chronicity. The findings revealed no correlation between the task perceptions of the nurses and their views on chronicity.

Since changes in psychiatric hospitals have led to a discussion of the professional identity of psychiatric nurses, this study examined whether the professional identification of the nurses was correlated with their task perceptions. In this regard two professional nursing roles were identified: the role of the nurse as a nurse and the role of the nurse as a therapist. In this study a low correlation was found between task perceptions and professional identification. Those nurses who identified themselves with the therapeutic role tended to be more therapyoriented. Nurses who identified themselves with the nursing role devote more time to consullative and coordinative tasks.

During the exploratory phase of the study several nurses working in managerial roles in psychiatric hospitals emphasized the importance of the phenomenon of burnout. Burnout is described in the literature as characterized by the following:

- a feeling of emotional exhaustion;

- a feeling of depersonalization;

- and a sense of reduction in personal accomplishment. 
Burnout is said to lead to a decline in the quality of health care. In terms of this study one would expect that high burnout would lead to fewer patient teaching activities and more care activities. However the results from this study revealed only a correlation between burnout and patient teaching activities. The higher the burnout the less time nurses devoted to patient teaching activities. A general conclusion about the nature of this relationship can only be made with some reservation. Considering that all data were gathered concurrently no causal interpretation can be attributed to the results.

Although during the pre-study phase the impression existed that there was a difference in tasks between male and female psychiatric nurses, the findings did not confirm this idea. Multivariate analysis revealed that the differences which appear in the task perceptions between male and female nurses were correlated with differences between the groups in relation to other characteristics such as function, experience and type of unit.

The study finding that the task perception differs between managerial and nonmanagerial nursing staff is not surprising. It is interesting, however, that the same difference in tasks of care also exists between non managerial nurses who have relatively little experience and nurses who are working relatively long as a nonmanagerial nurse.

The most important conclusion from this study is that task perceptions of nurses differed among the six psychiatric hospitals. Some psychiatric hospitals are more care-oriented while others are more patient teaching oriented. Similar differences were found between the long-term and the short-term units. Nurses working on long-term units tended to be more care-oriented, while their colleagues working on short-term units tended to be more therapy oriented. The difference between long-and short-term units is obvious because of the different types of patients on the two types of units. Interesting however, is the fact that no uniform pattern between the long-term and the short-term units was found across the psychiatric hospitals. For example within one hospital the nurses on the short-term units were more care oriented than those on long-term units. The differences in the task perceptions between the psychiatric hospitals as well as between the units lead to questions about the reasons for these differences. In this study the reasons for the differences between psychiatric hospitals were not investigated. However, differences in policy and/or organization culture between the psychiatric hospitals may offer an explanation in further studies. Further research on the reasons of the differences in task perception between psychiatric hospitals needs to be done. The fact that these differences are, in a way, differences in quality of care, implies that research of this nature is important to the care of psychiatric patients. 


\section{CURRICULUM VITAE}

Theo Dassen werd geboren te Kerkrade op 6 december 1953. Ongeveer een jaar na het behalen van het M.U.Lo.-B diploma begon hij in Noordwijkerhout bij het psychiatrisch centrum St.Bavo aan de opleiding tot psychiatrisch verpleegkundige. $\mathrm{Na}$ het behalen van het diploma ziekenverpleging-B (1976) heeft hij enige tijd werkervaring opgedaan als psychiatrisch verpleegkundige. Daarna heeft hij bij het Academisch Ziekenhuis te Leiden zijn A-diploma behaald (1979). Aan de toenmalige Hoge School voor Gezondheidszorg te Leusden behaalde hij in 1980 het diploma 'docent in de gezondheidszorg', Via een colloquium doctum werd hij in 1980 toegelaten tot de studie gezondheidswetenschappen (toen sociale gezondheidkunde geheten) aan de Rijksuniversiteit Limburg. In 1984 behaalde hij het diploma gezondheidswetenschappen met als afstudeerrichting verplegingswetenschap. Daarna is hij gedurende een jaar parttime werkzaam geweest bij de het M.D.G.o. te Maastricht, waar hij betrokken was bij de voorbereiding van de opleiding M.D.G.O.-vp. In datzelfde jaar volgde hij een postdoctorale onderzoekersopleiding aan de Rijksuniversiteit Limburg. Na het voltooien van die opleiding (1985) is hij in dienst getreden bij de vakgroep verplegingswetenschap waar hij voornamelijk gewerkt heeft aan onderzoek naar taken van psychiatrisch verpleegkundigen. Ook verrichtte hij in die periode een landelijk onderzoek naar het medisch handelen van intensive-care verpleegkundigen. Vanaf september 1989 is hij parttime als onderzoeker werkzaam bij de vakgroep verplegingswetenschap aan de Rijksuniversiteit Limburg en als docent bij de Posthogere Opleiding Verplegingswetenschap te Groningen. 
